\title{
Switchgrass potential on reclaimed surface mines for biofuel production in West Virginia
}

\author{
Michael A. Marra \\ West Virginia University
}

Follow this and additional works at: https://researchrepository.wvu.edu/etd

\section{Recommended Citation}

Marra, Michael A., "Switchgrass potential on reclaimed surface mines for biofuel production in West Virginia" (2012). Graduate Theses, Dissertations, and Problem Reports. 114.

https://researchrepository.wvu.edu/etd/114

This Thesis is protected by copyright and/or related rights. It has been brought to you by the The Research Repository @ WVU with permission from the rights-holder(s). You are free to use this Thesis in any way that is permitted by the copyright and related rights legislation that applies to your use. For other uses you must obtain permission from the rights-holder(s) directly, unless additional rights are indicated by a Creative Commons license in the record and/ or on the work itself. This Thesis has been accepted for inclusion in WVU Graduate Theses, Dissertations, and Problem Reports collection by an authorized administrator of The Research Repository @ WVU. For more information, please contact researchrepository@mail.wvu.edu. 


\title{
Switchgrass potential on reclaimed surface mines for biofuel production in West Virginia
}

\author{
Michael A. Marra \\ Thesis submitted to the \\ College of Agriculture, Natural Resources and Design \\ At West Virginia University \\ In partial fulfillment for the requirements for the degree of \\ Master of Science \\ In \\ Plant and Soil Science
}

Committee:

Dr. Jeffery Skousen, Chair

Dr. Thomas Griggs

Dr. Alan Sexstone

Division of Plant and Soil Sciences

West Virginia University

Morgantown, WV

Keywords: Switchgrass; Panicum virgatum; Biofuel; Reclamation, Copyright 2012 Michael A. Marra 


\title{
ABSTRACT
}

\section{Switchgrass potential on reclaimed surface mines for biofuel production in West Virginia}

\author{
Michael A. Marra
}

The high cost and environmental risks associated with non-renewable energy sources has caused an increased interest in, and development of renewable biofuels. Switchgrass (Panicum virgatum L.), a warm season perennial grass, has been investigated as a source of biofuel feedstock due to its high biomass production on marginal soils, its tolerance of harsh growing conditions, and its ability to provide habitat for wildlife and soil conservation cover. West Virginia contains vast expanses of reclaimed surface mine lands and could potentially benefit from the production of switchgrass as a biofuel feedstock. Furthermore, switchgrass production could satisfy Surface Mining Reclamation and Control Act of 1977 (SMCRA) requirements for reclamation bond release to mine operators. Three separate studies will be discussed in this thesis to determine if switchgrass grown on reclaimed surface mines can produce yields similar to yields from stands grown under normal agronomic conditions and what common surface mining reclamation practices may be most appropriate for growing switchgrass. The first study examined yield production of three commercially-available, upland switchgrass varieties grown on two reclaimed surface mines in production years two, three and four. The Hampshire Hill mine site, which was reclaimed in the late 1990s using top soil and treated municipal sludge, averaged 5,800 kg (ha-yr) ${ }^{-1}$ of switchgrass compared to $803 \mathrm{~kg}$ (ha-yr) ${ }^{-1}$ at the Hobet 21 site which was reclaimed with crushed, unweathered rock over compacted overburden. Site and variety interacted with Cave-in-Rock as the top performer at the more fertile Hampshire Hill site and Shawnee produced the highest yields at Hobet 21 (7,853 $\mathrm{kg} \mathrm{ha}^{-1}$ and $1,086 \mathrm{~kg} \mathrm{ha}^{-1}$ averaged across years, respectively). Switchgrass yields increased from 2009 to 2010, but declined from 2010 to 2011. Switchgrass yields from farmlands in this region averaged about $15000 \mathrm{~kg}$ (ha-yr) $)^{-1}$ in the research literature, so switchgrass grown on reclaimed lands appears to be about $50 \%$ lower. A second study to determine optimal nitrogen and mulch rates for switchgrass establishment began in June 2011 on two newly-reclaimed surface mines. Both sites were seeded at a rate of $11.2 \mathrm{~kg}$ pure live seed (PLS) ha ${ }^{-1}$ of Cave-in-Rock on replicated treatments of $0,33.6$ and $67.0 \mathrm{~kg} \mathrm{~N} \mathrm{ha}^{-}$ ${ }^{1}$, and high and low mulch rates of mulch applied as hydromulch. Switchgrass cover, frequency and yield improved with the addition of any amount of $\mathrm{N}$ fertilizer compared to no $\mathrm{N}$ application. There was no significant difference in yield associated with high and low levels of $\mathrm{N}$. We also observed that yields were not affected by application of additional mulch. The final study compared a one- and two-harvest system in the fourth year of production at the Hampshire Hill and Hobet 21 sites. There was no increase in yield production utilizing a two-harvest system (2922 kg (ha-yr) $)^{-1}$, averaged across site) compared to a one-harvest system $\left(3029 \mathrm{~kg}(\mathrm{ha}-\mathrm{yr})^{-1}\right)$. The data also showed that re-growth collected from July to October in the two-harvest system added negligible yield and that yield collected in July was comparable in one- and two-harvest systems 


\section{ACKNOWLEDGMENTS}

This thesis would not be possible without the help and support from a number of individuals. Many thanks are owed to the various other participants in this research who have offered their time, resources and assistance throughout my graduate career. My advisor, Dr. Jeff Skousen, was a wealth of information as well as a source of motivation, support and guidance throughout every aspect of the research process and graduate school. Committee members, Dr. Tom Griggs and Dr. Alan Sexstone, were always helpful and whose office doors were always open for questions and advice. I would also like to thank all the other faculty members for never turning me away for questions and when seeking advice.

Special thanks to Brady Gutta and Paul Ziemkiewicz of the WV Water Research Institute; Bill Oldani, George Thornsbury and Hobet Mining; Rick Adams and Arch Coal; Scot Shumaker, Rodney Mangold and The Upper Potomac River Commission; Kermit Fincham and Black Castle Mining, and West Virginia DEP.

Additionally, this research would not be possible without the help and knowledge of John Burkhart, who greatly assisted with the statistical analysis of this research. Special thanks to Nick Beaver for his hard work and great attitude in the field and in the lab.

Lastly, I would like to thank my wife, Chelsea, as well as my family and friends for their constant support. 


\section{TABLE OF CONTENTS}

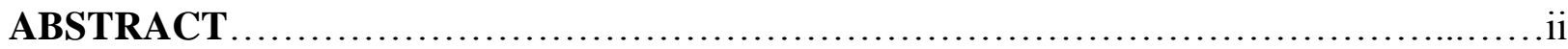

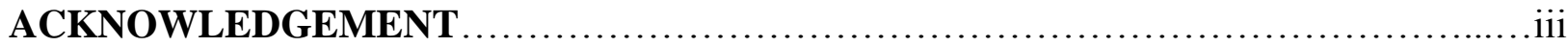

TABLE OF CONTENTS ..............................................................

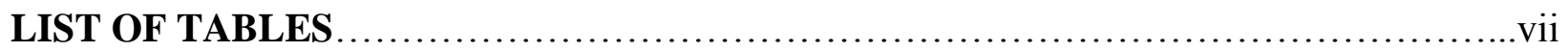

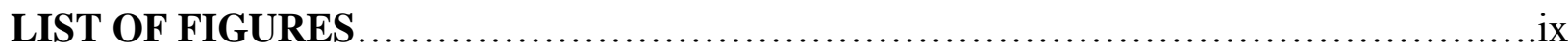

CHAPTER 1: Background and Objectives...........................................

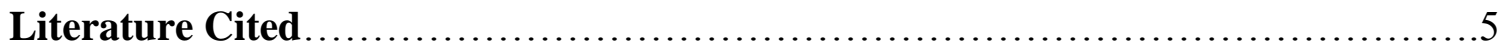

CHAPTER 2: Literature Review....................................................

2.1. Introduction to Switchgrass .............................................

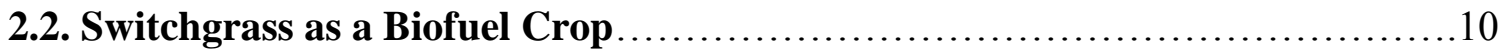

2.3. Switchgrass Establishment ................................................ 12

2.4. Switchgrass under Multiple Harvest Management Systems...................13

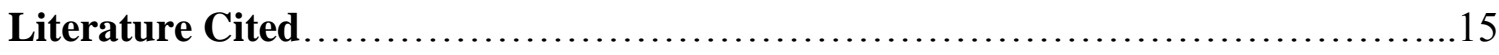

CHAPTER 3: Switchgrass Production on Reclaimed Surface Mines in West Virginia Three

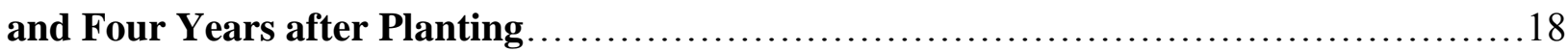

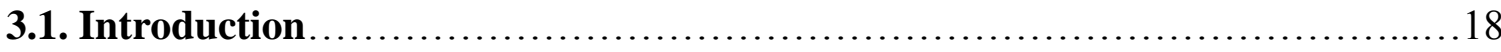

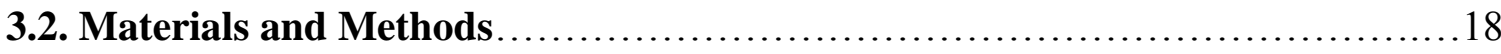

3.2.1. Site Locations ....................................................... 18

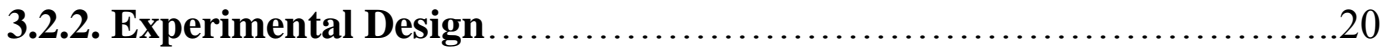

3.2.3. Vegetation Measurement and Analysis...........................22

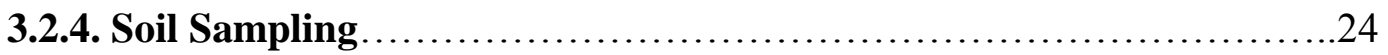

3.2.5. Soil Chemical Measurement and Analysis...........................24

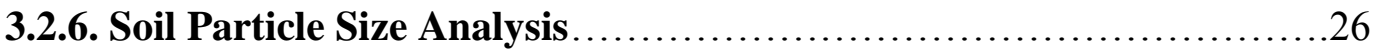




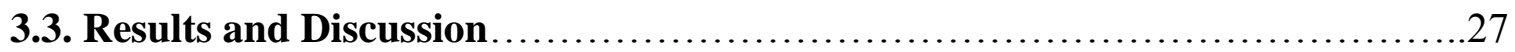

3.3.1. Vegetation Measurement.......................................27

3.3.2. Soil Chemical and Physical Properties............................. 35

3.3.3. Soil Particle Size Analysis...................................... 38

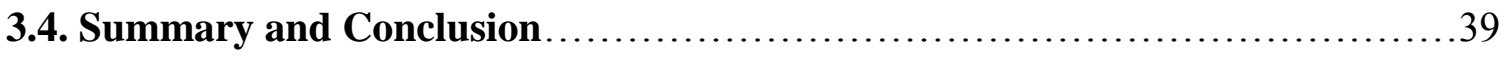

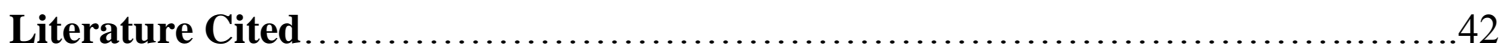

CHAPTER 4: Switchgrass establishment methods on newly reclaimed surface mines in

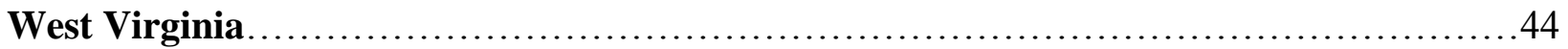

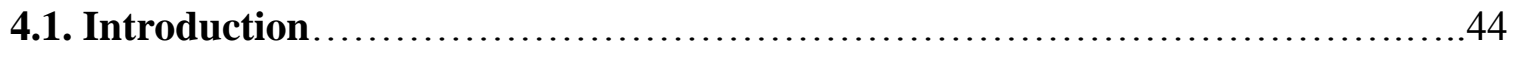

4.2. Materials and Methods............................................ 44

4.2.1. Site Locations...........................................44

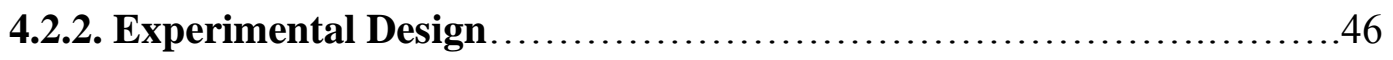

4.2.3. Vegetation Measurement and Analysis..........................48

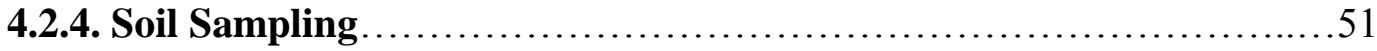

4.2.5. Soil Chemical Measurement and Analysis.......................51

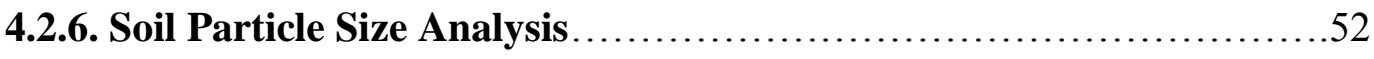

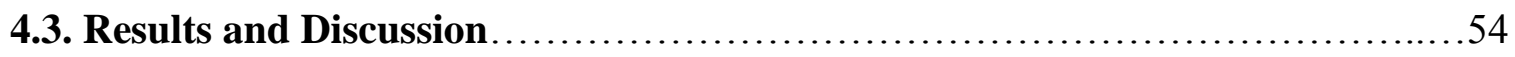

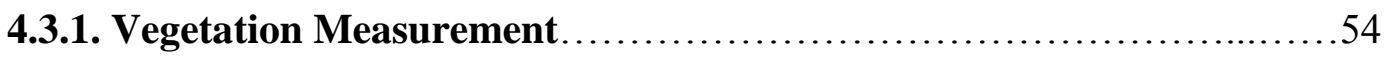

4.3.2. Soil Chemical and Physical Properties.........................60

4.3.3. Soil Particle Size Analysis..................................64

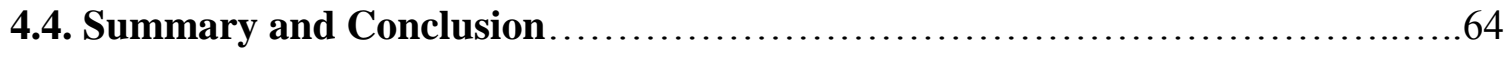

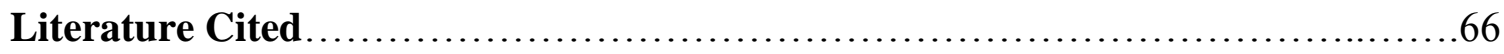

CHAPTER 5: Yield potential of a one- and two-harvest system for switchgrass grown on two reclaimed surface mines in West Virginia....................................6

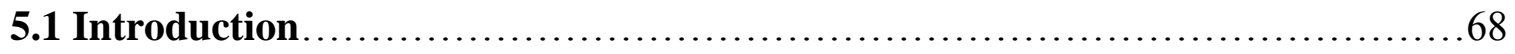

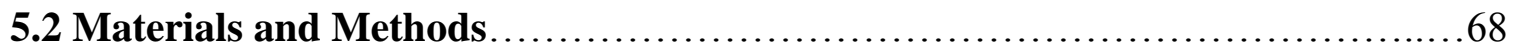


5.2.1. Site Locations................................................ 68

5.2.2. Experimental Design ......................................6 69

5.2.3. Vegetation Measurement and Analysis.......................... 70

5.3. Results and Discussion............................................. 73

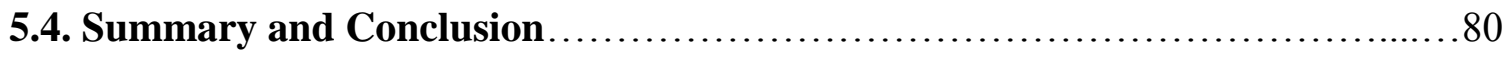

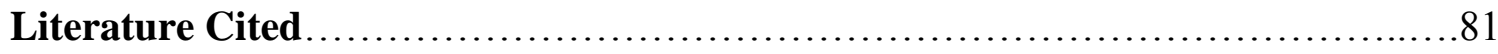

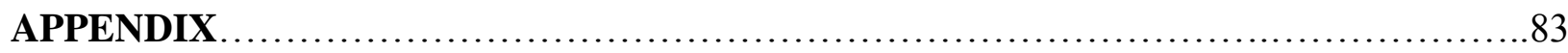

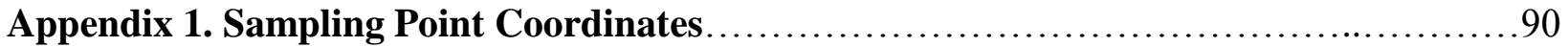

Appendix 2. Repeated Measures ANOVA Results and mean yields for Switchgrass grown on reclaimed surface mines during the second, third and fourth years of growth.........96 Appendix 3. Two-way ANOVA Results and mean yields for Switchgrass grown using four

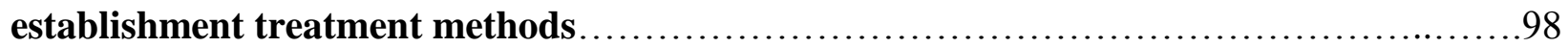

Appendix 4. ANOVA Results and mean yields for Switchgrass grown under a one- and two-harvest system. 


\section{LIST OF TABLES}

Table 3.1 Repeated measures ANOVA table with yield as the response variable.

Table 3.2 Repeated Measures ANOVA results and mean yields for Switchgrass grown on reclaimed surface mines during the second, third and fourth years of growth.......28

Table 3.3 Switchgrass yield by variety and site averaged across years......................30

Table 3.4 Switchgrass yield by year averaged across sites and varieties....................31

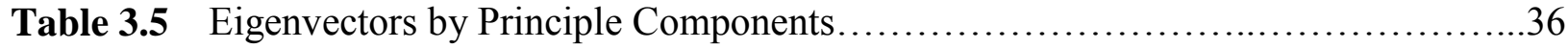

Table 3.6 Site means of all soil chemical and physical properties.............................

Table 3.7 Soil particle size distribution by site plus or minus one standard deviation.........39

Table 4.1 Type 3 Analysis of effects for percent cover................................55

Table 4.2 Percent frequency of switchgrass by site and treatment........................55

Table 4.3 Two-way ANOVA table with yield as response variables.......................56

Table 4.4 Two-way ANOVA Results and mean yields for Switchgrass grown using four establishment treatment methods.......................................56

Table 4.5 Untransformed treatment yields at Black Castle and Coal-Mac...................59

Table 4.6 Eigenvectors by Principle Components................................61

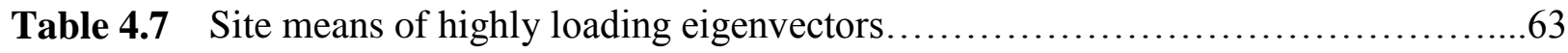

Table 4.8 Soil particle size distribution by site plus or minus one standard deviation.........64

Table 5.1 Harvest type ANOVA table with yield as the response variable. Yield in this analysis used one-harvest system and total of two-harvest system data.............74

Table 5.2 Table 3.2 from Chapter 3 showing significance associated with the main effects, site and variety in a repeated measures ANOVA with yield as the response variable .74

Table 5.3 Harvest type ANOVA table with yield as the response variable. Yield in this analysis used all one- and two- harvest system data, including yields collected in July only, regrowth only, and total combined yield, along with the one-harvest system. 
Table 5.4 ANOVA Results and mean yields for switchgrass grown under a one- and two-

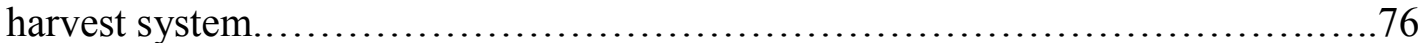

Table 5.5 Contrasts of switchgrass yield by harvest type ............................... 77

Table 5.6 Untransformed switchgrass yield by harvest time and site........................78 


\section{LIST OF FIGURES}

Figure 2.1 Switchgrass, though a bunch grass, is beginning to form a thick sod over time at

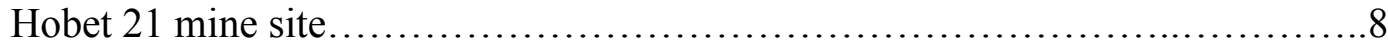

Figure 3.1 Location of the Hampshire Hill and Hobet 21 mine sites in West Virginia........19

Figure 3.2 Site layout at Hampshire Hill showing varieties and sampling points............21

Figure 3.3 Site layout at Hobet 21 showing varieties and sampling points. ................22

Figure 3.4 Precipitation and temperature data from NOAA for Keyser, WV and Madison, WV weather stations ....................................................

Figure 3.5 Biplot displaying sites and factor loadings of soil chemical and physical variables

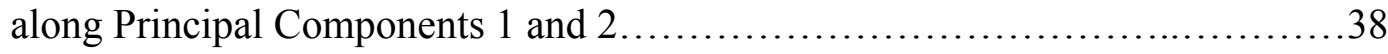

Figure 4.1 Location of Coal-Mac and Black Castle mine sites in West Virginia............45

Figure 4.2 Site layout of Coal-Mac showing plots, treatments and sampling points.........47

Figure 4.3 Site layout of Black Castle showing plots, treatments and sampling points........48

Figure 4.4 Percent cover measured using modified Daubenmire Method....................50

Figure 4.5 Interaction plot of square root transformed yield data by site and treatment.......57

Figure 4.6 Biplot displaying sites and factor loadings of soil chemical and physical variables

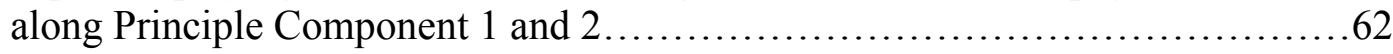

Figure 5.1 Site layout of Hampshire Hill showing varieties and sampling points............69

Figure 5.2 Site layout of Hobet 21 showing varieties and sampling points................70

Figure 5.3 Two-harvest switchgrass biomass collection- showing brightly painted wooden stake placed at the bottom left corner of quadrat.............................. 72 


\section{1: Background and Objectives}

Coal mining has long been a major industry in West Virginia's economy for the past century. West Virginia has been in the top three coal-producing states in the US since 1920, mining an average of 150 million Mg of coal per year (WV Coal Association, 2011). In 2010, West Virginia produced 46 million Mg of coal from 100 surface mines and 78 million Mg of coal from 152 underground mines (U.S. Energy Information Administration, 2011a). This extensive coal mining over the years, in particular surface mining, has produced large expanses of reclaimed land in the state. In 2005, a Programmatic Environmental Impact Statement prepared by the Environmental Protection Agency (EPA) for Mountaintop Mining/Valley Fills in Appalachia estimated 4.9 million ha to be affected by mining activities in West Virginia, eastern Kentucky and a few counties in Tennessee (U.S. EPA, 2005). Not only due to the sheer magnitude of land area affected by surface mining, but also due to the major environmental and health risks associated with it, proper reclamation of mined land is a necessary and regulated activity for mine operators. In addition, large penalties in terms of money and future mining prospects are at stake if a mining operation fails to properly return mined land to an acceptable condition.

In 1977, the Surface Mining Control and Reclamation Act (SMCRA) was enacted to encourage proper reclamation of active mining as well as to reclaim previously abandoned mine land. To encourage proper mine reclamation, SMCRA requires mine operators to post sufficient bonds to cover the complete cost of reclamation should a mining operation fail to properly reclaim the land themselves. SMCRA also requires mine operators to specify how land will be used after reclamation is complete. Bonds are released to the mine operator when the land is 
properly reclaimed and utilized for the Post Mining Land Use (PMLU) specified in the mining permit.

From July 1, 2010 through June 30, 2011, the West Virginia Department of Environmental Protection (WV DEP) granted Phase III bond release to 2,152 ha of land (WV DEP, 2011). The PMLU category with the most area of land released in that time period was hayland and/or pasture, followed by wildlife habitat and forest, respectively (WV DEP, 2011). Popular PMLU's such as pasture and hayland allow mine operators to recover bonds relatively quickly, easily, and at a low cost while reducing the environmental and health affects which SMRCA seeks to avoid. However, PMLU's with potential for additional economic return, such as pasture or hardwood forests, offer incentives to land owners beyond bond release. Another alternative PMLU, potentially economical and environmentally-friendly, is the production of biofuel feedstocks which can provide biomass for alternative fuels.

Biofuel feedstock is the term given to crops or other organic sources used as inputs for production of bioenergy. Currently, bioenergy production has gained considerable interest in the U.S. In 2010, biomass-based fuels provided about $4 \%$ of the energy in the United States, of which $43 \%$ was from biofuels (U.S. EIA, 2011b). The use of petroleum products, which make up $94 \%$ of consumed transportation fuel in the United States (U.S. EIA: Office of Statistics, 2011), as well as the increased environmental concerns associated with fossil fuels, have sparked abundant research in the development of bioenergy. This recent growth of renewable energy, particularly biofuel created from the conversion of plant-based material to ethanol, has increased the demand for reliable feedstocks.

The majority of the United States' current biofuel demand is met by the conversion of corn grain (Zea mays L.) to ethanol. Concerns associated with food demands, use of good quality 
farm land to produce fuel rather than food, and energy and carbon balance of bioenergy production has led researchers to examine other biofuel feedstock options. Many perennial herbaceous plants and crop residues have been evaluated as sources of cellulosic material to be converted to biofuel. Perennial herbaceous plants can also be used to produce "biopower," the term sometimes used to describe heat or electricity produced from burning biomass (Parrish et al., 2008).

Switchgrass (Panicum virgatum L.), a warm season perennial grass native to North America and commonly used as a conservation and forage species, has been investigated extensively as a source of biofuel feedstock. An assessment of several herbaceous feedstocks initiated in the 1980's and conducted by the United States Department of Energy (USDOE) led to the selection of switchgrass as a "model" bioenergy feedstock (Lynd et al., 1991; Sanderson et al., 1996; McLaughlin and Walsh, 1998; McLaughlin and Kszos, 2005).

Growing switchgrass as a biomass feedstock on reclaimed surface mines offers a unique opportunity as a PMLU. Switchgrass, or any other biofuel crop, can provide the groundcover necessary to meet SMCRA reclamation standards to control erosion (>90\% cover), and it can also produce a crop that can be cut for biomass for income by the succeeding landowner who takes back the land after mining and reclamation. The main objective of this research is to determine the ability of reclaimed surface mines to produce viable switchgrass stands for biomass production. Two main research questions will be addressed in the following chapters of this thesis. 1) What yields could be expected from switchgrass grown on reclaimed surface mines in West Virginia? 2) What establishment methods, common to surface mine reclamation practices used in this area, and harvest system may be the most appropriate for growing switchgrass on reclaimed surface mines? 
The results of three separate studies will be discussed in subsequent chapters of this thesis in order to address both research questions listed above. Chapter 3 will examine switchgrass yield three and four years after planting of three switchgrass varieties on two very different surface mines in West Virginia. One site, Hobet 21, was reclaimed using reclamation practices standard to most mining operations in this area and was planted with switchgrass the same year after regrading and leveling. In contrast, another site, Hampshire Hill, was reclaimed with 15-30 $\mathrm{cm}$ of topsoil and then amended with lime-treated sewage sludge from a nearby wastewater treatment plant and revegetated with mixed cool-season species over a decade prior to switchgrass establishment. Yields of switchgrass and soil chemical and physical characteristics of soils were examined in this study. Chapter 4 of this thesis reports on establishment of switchgrass on two mine sites, similar in operation style and reclamation to Hobet 21 . Both mine sites used for this study were reclaimed and planted in the same year. This second study looked at one switchgrass variety established using varying treatments of nitrogen $(\mathrm{N})$ fertilizer and hydromulch application. The treatments chosen were in line with regulation guidelines for revegetation practices in West Virginia. Yields of switchgrass and soil chemical and physical characteristics were also examined in this study. The fifth and final chapter of this thesis compared yield potential of a one- and two-harvest system for switchgrass stands grown on Hobet 21 and Hampshire Hill. 


\section{Literature Cited}

Lynd, L.R., J.H. Cushman, R.J. Nichols and C.E. Wyman. 1991. Fuel ethanol from cellulosic biomass. Science 251:1318-1323.

McLaughlin, S.B. and M.E. Walsh. 1998. Evaluating environmental consequences of producing herbaceous crops for bioenergy. Biomass and Bioenergy 14.4: 317-324.

McLaughlin, S.B. and L.A. Kszos. 2005. Development of switchgrass (Pancium virgatum) as a bioenergy feedstock in the United States. Biomass and Bioenergy 28: 515-535.

Parrish, D.J., J.H. Fike, D.I. Bransby and R. Samson. 2008. Establishing and managing switchgrass as an energy crop. Forage and Grazinglands doi: 10.1094/FG-2008-0220-01RV.

Sanderson, M.A., R.L. Reed, S.B. McLaughlin, S.D. Wullshleger, B.V. Conger, D.J. Parrish, D.D. Wolf, C. Taliaferro, A.A. Hopkins, W.R. Ocumpaugh, M.A. Hussey, J.C. Read and C.R. Tisher. 1996. Switchgrass as a Sustainable Bioenergy Crop. Bioresource Technology 56:83-93.

U.S. Environmental Protection Agency. 2005. Mountaintop Mining/Valley Fills in Appalachia Final Programmatic Environmental Impact Statement. EPA Region 3. Philadelphia, PA. EPA 9-03-R-05002.

U.S. Energy Information Administration. 2011a. Annual Coal Report 2010. Report No: DOE/EIA-0584 (2010). http://www.eia.gov/coal/annual/pdf/table1.pdf. Department of Energy, Washington, DC.

U.S. Energy Information Administration. 2011b. Biomass Explained. http://www.eia.gov/energyexplained/index.cfm?page=biomass.home (Lasted updated: June 1, 2011). U.S. Department of Energy, Washington, DC.

U.S. Energy Information Administration; Office of Statistics. 2011. Annual Energy Review 2010. DOE/EIA-0384 (2010). http://www.eia.gov/totalenergy/data/anual/pdf/aer.pdf. U.S. Department of Energy, Washington, DC.

West Virginia Coal Association. 2011. West Virginia Coal: Fueling an American renaissance 2011. West Virginia Coal Association, Charleston, WV. http://www.wvcoal.com/2011coal-facts.html 
West Virginia Department of Environmental Protection. 2011. WV DEP Annual Evaluation Report.http://www.arcc.osmre.gov/FOs/CHFO/WV/AR/EY2011-WV

ARFI.pdf.Charleston Field Office, Office of Surface Mining and Enforcement. Charleston, WV. 


\section{2: Literature Review}

\subsection{Introduction to Switchgrass}

Switchgrass is a tall, warm-season grass which can grow up to $3 \mathrm{~m}$ and can form dense sods over time. Its native habitat was originally the tall grass prairie. Native stands were most abundant east of $100^{\circ}$ longitude, north to Nova Scotia and Ontario, and south to Mexico and Central America (Hitchcock, 1971; Vogel, 2004). In general, switchgrass tolerates low fertility, persists in acid to moderately alkaline soils, and is tolerant of drought and heat. It is considered the model feedstock of the herbaceous energy crops because of its high productivity, wide geographic range, ability to grow on marginal land, and low water and nutrient requirements.

Switchgrass has a panicle inflorescence and a round, hard stem (Hitchcock, 1971; Moore, 2003). A fringed, hairy ligule is a common identification characteristic for the species.

Switchgrass leaves are flat, have rough margins, and are rolled in the whorl (Moore, 2003). Switchgrass habitat consists of fields, prairies, woods, waste ground, moist seepage areas of cliffs and along stream beds (Mohlenbrock, 1973). Most genotypes are caespitose, or tuftforming, however, switchgrass forms a dense sod over time by growth of numerous, scaly rhizomes (Hitchcock, 1971; Vogel, 2004) (Figure 2.1).

Varieties or cultivars of switchgrass are placed in two distinct ecotypes or "cytotypes:" upland and lowland (Casler, 2005). Lowland ecotypes are found on areas prone to flooding, prefer moist soil conditions, and tend to be more coarse and taller than upland ecotypes. Upland ecotypes typically favor drier soils and more semi-arid climates (Vogel, 2004). Lowland ecotypes have a tetraploid $(2 \mathrm{n}=36)$ chromosome number and upland types have hexaploid $(2 \mathrm{n}=$ 54) or octaploid $(2 \mathrm{n}=72)$ chromosome number (Porter, 1966). Both ecotypes have short rhizomes and are deeply rooted (Parrish et al., 2008). 
Figure 2.1: Switchgrass, though a bunch grass, is beginning to form a thick sod over time at Hobet 21 mine site.

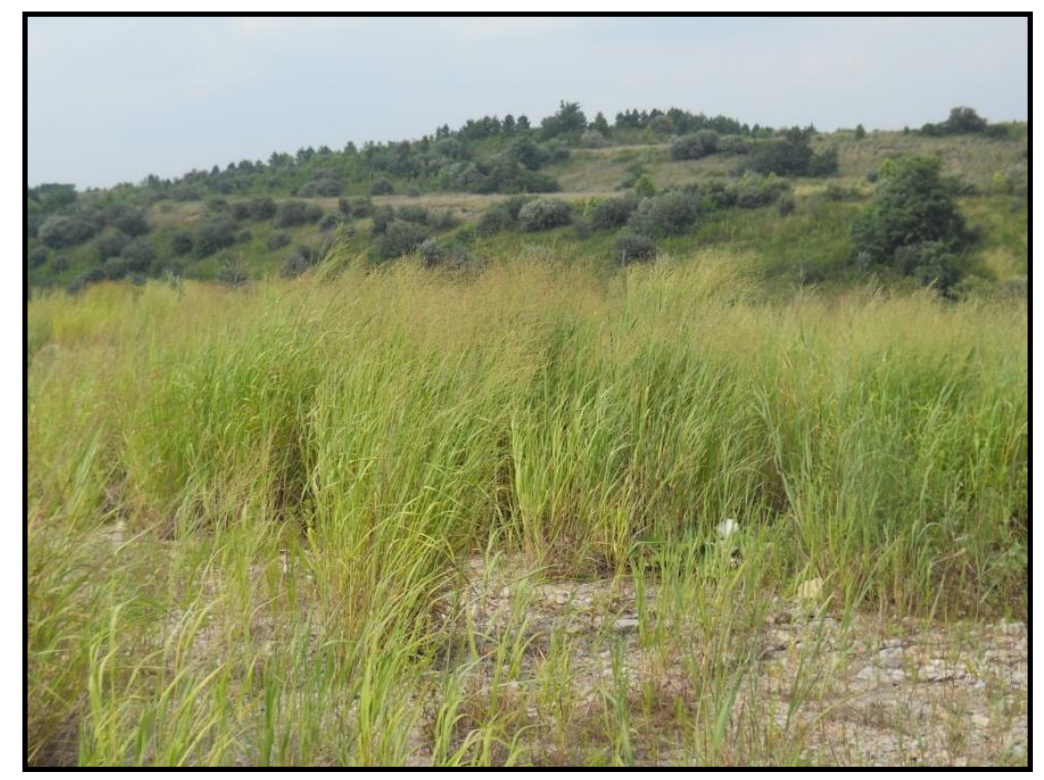

Switchgrass has potential to produce high yields across a wide range of growing environments. A three-year study conducted by Fike et al. (2006a) showed yields of 14,100 kg $(\text { ha-yr) })^{-1}$ averaged across four cultivars from eight sites in five southeastern U.S. states, including West Virginia. Similarly, yields as high as $14,900 \mathrm{~kg}$ (ha-yr) ${ }^{-1}$ were reported from three states located in the Midwestern U.S. (Vogel and Masters, 1998). Yields of over 22,400 kg (ha-yr) ${ }^{-1}$ have also been reported west of the Rocky Mountains on irrigated research plots in Washington (Fransen, 2009). Switchgrass is also capable of producing high yields from stands that have been in place for long time periods. Biomass yields from production years six through nine in research conducted by Fike et al. (2006b) in mid-Atlantic States averaged 14,200 kg (ha-yr) ${ }^{-1}$. In a 10-year study sponsored by the USDOE which had field sites in 13 states, average yearly yields of the three best commercial cultivars were 12,000 to $19,000 \mathrm{~kg} \mathrm{ha}^{-1}$ and 11,600 to 15,500 
$\mathrm{kg} \mathrm{ha}^{-1}$ for Alamo and Kanlow, respectively; and 13,500 to $18,600 \mathrm{~kg} \mathrm{ha}^{-1}$ for Cave-in-Rock (in a two-cut system at Southeastern sites) (McLaughlin and Kszoz, 2005).

Many studies have found that switchgrass can be successfully grown as biomass feedstock (Sanderson et al., 1996; Lemus et al., 2002; Mclaughlin and Kszoz, 2005; Fike et al., 2006a; Fike et al.2006b; Mclaughlin and Kszoz, 2005; Fransen, 2009), but using agricultural cropland for biomass production has raised controversy. With a world population now over 7 billion (Population Reference Bureau, 2012) and malnutrition affecting nearly 800 million (WHO, 2000), the idea of growing fuel instead of food on prime farmland areas for a growing world population raises many concerns and debates. As biofuels production gains popularity through policy-makers, concerns arise that more agricultural land will be used for biofuel production which will then increase demand and costs of food (Chakravorty et al., 2009). One key barrier to the success of energy production from biomass, beside costs and conversion processes, is feedstock availability which includes competition for arable land with food and fiber production (IEA, 2007). Finding a way to produce biomass feedstock without utilizing agricultural land could benefit the biofuel industry.

One potential solution to this problem is to grow bioenergy crops like switchgrass on marginal lands to reduce the agricultural acreage devoted to bioenergy crops. Because of switchgrass' characteristics and ability to grow on marginal land, it has been chosen as a crop to be grown and studied on such lands. One such example is switchgrass grown on Conservation Reserve Program (CRP) land (Mulkey et al., 2006). In West Virginia, where many acres of marginal land exist as reclaimed surface mines, switchgrass may be adopted as a crop to produce biomass for biofuel. Developing an alternative PMLU such as production of biofuel from 
switchgrass would meet reclamation standards, and more especially provide economic incentives to landowners, and maintain environmental benefits.

Studies conducted on switchgrass grown on marginal land have shown adequate biomass production. Skousen and Venable (2008) established switchgrass along newly-constructed highways in West Virginia, which achieved good cover and soil stabilization after two years. Schmer et al. (2008) managed switchgrass as a biomass energy crop on marginal cropland on ten farms and produced annual average yields of 5,200 to $11,100 \mathrm{~kg} \mathrm{ha}^{-1}$. In mine soil collected from a surface mine in Pennsylvania, Dere et al. (2011) found that increased compost rates increased switchgrass growth compared to unamended mine soil. They also found that manure combined with paper mill sludge further increased switchgrass growth.

\subsection{Switchgrass as a Biofuel Crop}

Fuel ethanol produced by fermentation of starch and cellulosic crops is considered a clean alternative to petroleum energy. Currently, ethanol is blended with transportation fuel as a means to reduce air emissions, decrease demand for petroleum supplies, and increase energy security. In 2007, the Energy Independence and Security Act required that 9 billion gallons of renewable fuel be blended with transportation fuel by 2008 and 36 billion gallons of renewable fuel be blended with transportation fuel by 2022 in the U.S. This recent demand of renewable energy, in particular biofuel in the form of ethanol produced by plant-based material, has increased the demand for reliable feedstocks. Concerns associated with food demands and use of farm land to produce fuel has led researchers to examine other biofuel feedstock options as well as other lands not under intensive crop production. 
Switchgrass can be converted into energy by combustion, pyrolysis, gasification and fermentation (Faaij, 2006). To produce ethanol from switchgrass, the complex sugars, cellulose and hemicelluloses must be broken down into simple sugars, which can then be fermented biologically by microbes (Datar et al., 2004). Following fermentation, ethanol is recovered via distillation. Ethanol production from cellulosic materials is quite different than ethanol production from starch- and sugar-based food crops and is currently still in the experimental stage. Additional steps are required in the conversion process to make the fermentable sugars in herbaceous energy crops available to microbial digestion.

Two keys to the success of switchgrass as a viable biofuel feedstock are the quality and quantity of the feedstock and the biofuel industries' ability to effectively convert it to ethanol (Sarath et al., 2008). Lemus and Parrish (2009) estimate under a well-designed system that switchgrass can supply a potential ethanol yield of 3085 to 7573 liters $\mathrm{ha}^{-1} \mathrm{yr}^{-1}$ and offset greenhouse gases by 35 to $75 \%$ by incorporating carbon into above and below ground biomass and reducing tillage, fuel, and fertilizer. Another, more conservative estimate, which includes inputs for transportation and steam and electricity production for conversion, determine a negative energy return of 50\% for switchgrass conversion to ethanol (Pimentel and Patzek, 2005). Switchgrass can also be pelletized for use in stoves. If pelletized, Samson et al. (2004) estimate that for every $1 \mathrm{kcal}$ of fossil fuel invested in the production of switchgrass $14.6 \mathrm{kcal}$ will be returned in energy. 


\subsection{Switchgrass Establishment}

Switchgrass (Panicum virgatum L.) is relatively slow to establish after planting. It will typically reach only $33-66 \%$ of its production capacity during the first and second years of production (McLaughlin and Kszoz, 2005). However, once established switchgrass can grow very well under normal agronomic conditions. Two common problems with switchgrass establishment are seed quality and weed competition (Vogel, 2004; Schmer et al., 2008). Switchgrass seeds are very small compared to annual grains and therefore switchgrass seeds have little reserves for germination and initial growth. Planting seeds of good quality and with a high percentage of germinable seeds are important when establishing stands. Parrish et al. (2008) recommend a seeding rate of $11.2 \mathrm{~kg}$ pure live seed (PLS) $\mathrm{ha}^{-1}$. Wolf and Fiske (1995) recommend a seeding rate range of 8.9 to $11.2 \mathrm{~kg}$ pure live seed (PLS) ha ${ }^{-1}$ and Teel and Barnhart (2003) recommend slightly lower rates of 5.6 to $6.7 \mathrm{~kg} \mathrm{PLS} \mathrm{ha}^{-1}$. Seedbeds should be firm and seeds should be planted at a depth of 0.6 to $1.2 \mathrm{~cm}$ to ensure good soil to seed contact (Wolf and Fiske, 1995; Teel and Barnhart, 2003; Parrish et al., 2008). Switchgrass germinates best when soil temperatures are warm. Under normal agronomic conditions, $\mathrm{N}$ application is not commonly recommended at planting to reduce weed competition and if soil tests indicate medium or high phosphorous $(\mathrm{P})$ and potassium $(\mathrm{K})$ then no fertilizer is required (Wolf and Fiske, 1995; Parrish et al., 2008).

Switchgrass is a thrifty user of nutrients and is capable of growing with little to no amendments, including N, P, and K. Productive stands of switchgrass are possible with no amendments on marginal land (Balasko et al., 1984). Mulkey et al. (2006) reported $56 \mathrm{~kg} \mathrm{~N} \mathrm{ha}^{-1}$ was an effective application rate for switchgrass grown on land enrolled in CRP, or managed similarly to CRP, in South Dakota. Conversely, negative impacts associated with excessive N 
can impact yields. Fike et al. (2006a) reduced $\mathrm{N}$ application from $100 \mathrm{~kg} \mathrm{ha}^{-1}$ to $50 \mathrm{~kg} \mathrm{ha}^{-1}$ in their single harvest system due to indications of negative impacts such as increased lodging, decreased tiller density and decreased stand vigor. $\mathrm{N}$ fertilization of switchgrass for production of biofuels as well as forages varies greatly depending on region, soil type, management and climate (Parrish and Fike, 2005). For mine soils, the coarse textures and small amounts of fine material can cause problems for switchgrass establishment and growth. Besides purchasing seed with a high germination rate and minimizing weed competition, sound establishment practices need to be developed in order to successfully produce switchgrass on reclaimed mine soils.

\subsection{Switchgrass under Multiple Harvest Management Systems}

When managed as a biomass feedstock, maximum yields while maintaining long term stands with few inputs are desirable. Switchgrass has potential to be harvested up to several times during the growing season. Maximum yields of 10,500 to $12,600 \mathrm{~kg}$ (ha-yr) ${ }^{-1}$ were recorded in the Midwest when the variety Cave-in-Rock was harvested once per growing season during anthesis (Vogel, 2004). Conversely, Fike et al. (2006b) found that yields increased with a two-harvest management system compared to one-harvest management system when data were averaged across eight switchgrass sites in five states. In fact, this study also showed that the two upland cultivars used in the study (Cave-in-Rock and Shelter) had a 38\% increase in yield when harvested twice per year. Vogel et al. (2002) found an optimal time to harvest switchgrass for biomass in the Midwest is during the reproductive stage at the R3 to R5 stage of maturity (panicles fully emerged to postanthesis) (Moore et al., 1991) and sufficient regrowth may be obtained for a second harvest after a killing frost. 
This research examines switchgrass yield potential on marginal land, specifically reclaimed surface mines, for the potential end use of biofuel feedstock. The goal of this research is not to examine the quality of the material as any particular type of bioenergy feedstock, but to examine yield expectations, cultivar selection, and management practices of a specific biofuel crop grown on reclaimed surface mines. 


\section{Literature Cited}

Balasko, J. A., D.M. Burner and W.V. Thayne. 1984. Yield and quality of switchgrass grown without soil amendments. Agronomy Journal 76:204-208.

Casler, M.D. 2005. Ecotypic variation among switchgrass populations from the northern USA. Crop Science 45:388-398.

Chakravorty, U., M. Hubert and L. Nøstbakken. 2009. Fuel versus food. Annual Review of Resource Economics. 1:645-663.

Datar, R.P., R.M. Shenkman, B.G. Cateni, R.L. Huhnke and R.S. Lewis. 2004. Fermentation of biomass-generated producer gas to ethanol. Biotechnology and Bioengineering 86:587594.

Dere, A.L., R.C. Stehouwer and K.E. McDonald. 2011. Nutrient leaching and switchgrass growth in mine soil columns amended with poultry manure. Soil Science 176:84-90.

Faaij, A. 2006. Modern biomass conversion technologies. Mitigation and Adaption Strategies for Global Change 11: 343-375.

Fike, J.H., D.J. Parrish, D.D. Wolf, J.A. Balasko, J.T. Green, Jr., M. Rasnake and J.H. Reynolds. 2006a. Long-term yield potential of switchgrass-for-biofuel systems. Biomass and Bioenergy 30:198-206.

Fike, J.H., D.J. Parrish, D.D. Wolf, J.A. Balasko, J.T. Green, Jr., M. Rasnake and J.H. Reynolds. 2006b. Switchgrass production for the upper southeastern USA: Influence of cultivar and cutting frequency on biomass yields. Biomass and Bioenergy 30:207-213.

Fransen, S. 2009. Agronomics of switchgrass for biofuel in the west. In Proceedings, 2009 Western Alfalfa and Forage Conference, December 2-4, 2009. Reno, Nevada.

Hitchcock, A.S. 1971. Manual of the grasses of the United States(second edition revised by A. Chase). U.S. Department of Agriculture misc. publication No. 200. Dover Publications, Inc., New York. p.697.

IEA. 2007. Biomass for power generation and CHP. IEA Energy Technology Essentials ETE03. International Energy Agency. http://www.iea.org/publications/freepublications/publication/essentials3.pdf.

Lemus, R., E.C. Brummer, K.J. Moore, N.E. Molstad, C.L. Burras and M.F. Barker. 2002. Biomass yield and quality of 20 switchgrass populations in southern Iowa, USA. Biomass and Bioenergy 23:433-442. 
Lemus, R. and D.J. Parrish. 2009. Herbaceous crops with potential for biofuel production in the USA. CABI Reviews: Perspective in Agriculture, Veterinary Science, Nutrition and Natural Resources 4:1-23.

McLaughlin, S.B. and L.A. Kszos. 2005. Development of switchgrass (Pancium virgatum) as a bioenergy feedstock in the United States. Biomass and Bioenergy 28: 515-535.

Mohlenbrock., R.H. 1973. The Illustrated Flora of Illinois; Grasses panicum to danthonia. Southern Illinois University Press.

Moore, K.J., L.E. Moser, K.P. Vogel, S.S. Waller, B.E. Johnson and J.F. Pedersen. 1991. Describing and quantifying growth stages of perennial grasses. Agronomy Journal 83: 1073-1077.

Moore, K.J. 2003. Compendium of common forages. In Barnes, R.F., C.J. Nelson, M. Collinsand K.J. Moore. (ed.) 2003. Forages: An Introduction to Grassland Agriculture. $6^{\text {th }}$ ed. Iowa State Press, Ames.

Mulkey, V.R., V.N. Owens and D.K. Lee. 2006. Management of switchgrass-dominated Conservation Reserve Program lands for biomass production in South Dakota. Crop Science 46:712-720

Parrish, D.J. and J.H. Fike. 2005. The biology and agronomy of switchgrass for biofuels. Critical Reviews in Plant Sciences 24:423.

Parrish, D.J., J.H. Fike, D.I. Bransby and R. Samson. 2008. Establishing and managing switchgrass as an energy crop. Forage and Grazinglands doi: 10.1094/FG-2008-0220-01RV.

Population Reference Bureau. 2012. World Population data sheet. Population Reference Bureau, Washington, DC.

Pimentel, D. and T.W. Patzek. 2005. Ethanol production using corn, switchgrass, and wood; biodiesel production using soybean and sunflower. Natural Resources Research 14:65-76.

Porter, C.L. 1966. An analysis of variation between upland and lowland switchgrass, Panicum virgatum L., in central Oklahoma. Ecology 47:980-992.

Samson, R., P. Duxbury, and L. Mulkins. 2004. Research and development of fibre crops in cool season regions of Cananda. Resource Efficient Agricultural Production- Canada. http://www.reap-canada.com/library.htm.

Sanderson, M.A., R.L. Reed, S.B. McLaughlin, S.D. Wullshleger, B.V. Conger, D.J. Parrish, D.D. Wolf, C. Taliaferro, A.A. Hopkins, W.R. Ocumpaugh, M.A. Hussey, J.C. Read and C.R. Tisher. 1996. Switchgrass as a Sustainable Bioenergy Crop. Bioresource Technology 56:83-93. 
Sarath, G., R.B. Mitchell, S.E. Sattler, D. Funnell, J.F. Pedersen, R.A. Graybosch and K.P. Vogel. 2008. Opportunities and Roadblocks in Utilizing Forages and Small Grains for Liquid Fuels. Journal of Industrial Microbiology and Biotechnology 35:342-354.

Schmer, M.R., K.P. Vogel, R.B. Mitchell and R.K. Perrin. 2008. Net energy of cellulosic ethanol from switchgrass. Proceedings of the National Academy of Sciences 105: 464469.

Skousen, J.G. and C.L. Venable. 2008. Establishing native plants on newly-constructed and older-reclaimed sites along West Virginia highways. Land Degradation and Development 19:388-396.

Teel, A. and S. Barnhart. 2003. Switchgrass seeding recommendation for the production of biomass fuel in southern Iowa. Iowa State University Extension, Ames, IA.

Vogel, K.P. and R.A. Masters. 1998. Developing switchgrass into a biomass fuel crop for the Midwestern USA. Proc. BioEnergy 1998: Expanding Bioenergy Partnerships, Madison, WI. 4-8 Oct. 1998.

Vogel, K.P., J.J. Brejda, D.T. Walters and D.R. Buxton. 2002. Switchgrass biomass production in the Midwest USA: harvest and nitrogen management. Agronomy Journal 94: 413-420.

Vogel, K.P. 2004. Switchgrass. p. 561-583. In Moser, L.E., B.L. Burson and L.E. Sollenberger (ed.) Warm Season (C4) Grasses, Agronomy Monograph no. 45. ASA, CSSA, and SSSA, Madison, WI WHO. 2000. Turning the tide of malnutrition: responding to the challenge of the $21^{\text {st }}$ century. Geneva: World Health Organization 2000 (WHO/NHD/00.7)

Wolf, D.D. and D.A. Fiske. 1995. Planting and managing switchgrass for forage wildlife, and conservation. Virginia Cooperative Extension Pub. no. 418-013. Virginia Cooperative Extension, Blacksburg, VA. 


\section{3: Switchgrass production on reclaimed surface mines in West Virginia three and four years after planting.}

\subsection{Introduction}

This chapter of the research project will report on studies of switchgrass (Panicum virgatum L.) yield and soil physical and chemical properties on reclaimed surface mines in West Virginia. Specifically, this area of the project examined switchgrass grown on two surface mines during the third and fourth years of production to determine production potential of previously established switchgrass stands. The objective of this chapter is to determine what switchgrass yields might be expected when planted on reclaimed surface mines in West Virginia. Three common and commercially available upland switchgrass varieties were examined as a part of this study to determine which variety may produce the highest yields under similar management. Two mines, which were reclaimed and managed quite differently, were used as study sites for this study. These two sites represent the opposite ends of the reclamation spectrum; one site had topsoil and organic amendments versus the other with no topsoil and no amendments.

\subsection{Materials and Methods}

\subsubsection{Site Locations}

Two mine sites were used for study 1. Plot construction and switchgrass establishment took place in 2008 . The Hobet 21 site $(38.01618 \mathrm{~N}$ and $81.9676 \mathrm{~W})$, located on a large surface mine in Boone and Kanawha counties (Figure 3.1) operated by Hobet Mining Company, was mined and reclaimed in 2008. The study was conducted on a nearly level area of about $5 \mathrm{ha}$. The area was prepared by planting three switchgrass varieties on this 5-ha reclaimed area, with the surface being composed of 1-m of crushed, unweathered rock material overlaying compacted 
overburden material. The Hampshire Hill site $(39.4350 \mathrm{~N}$ and $79.0616 \mathrm{~W})$ is located on a small contour mine in Mineral County in the eastern panhandle of West Virginia (Figure 3.1). Mining at Hampshire Hill stopped in 1998 and was reclaimed by backfilling and grading to approximate original contour. The site is currently managed by the Upper Potomac River Commission. After grading, a 30-cm layer of top soil was applied and lime-treated municipal sludge from the Westernport, MD, municipal wastewater treatment facility was then blended into the topsoil at a rate of $225 \mathrm{Mg}$ (dry) ha ${ }^{-1}$ in 2000 (Keene and Skousen, 2009). Additional treatments of sludge from the wastewater treatment facility were applied in 2003 and again in 2008 before planting.

Figure 3.1: Location of the Hampshire Hill and Hobet 21 mine sites in West Virginia.

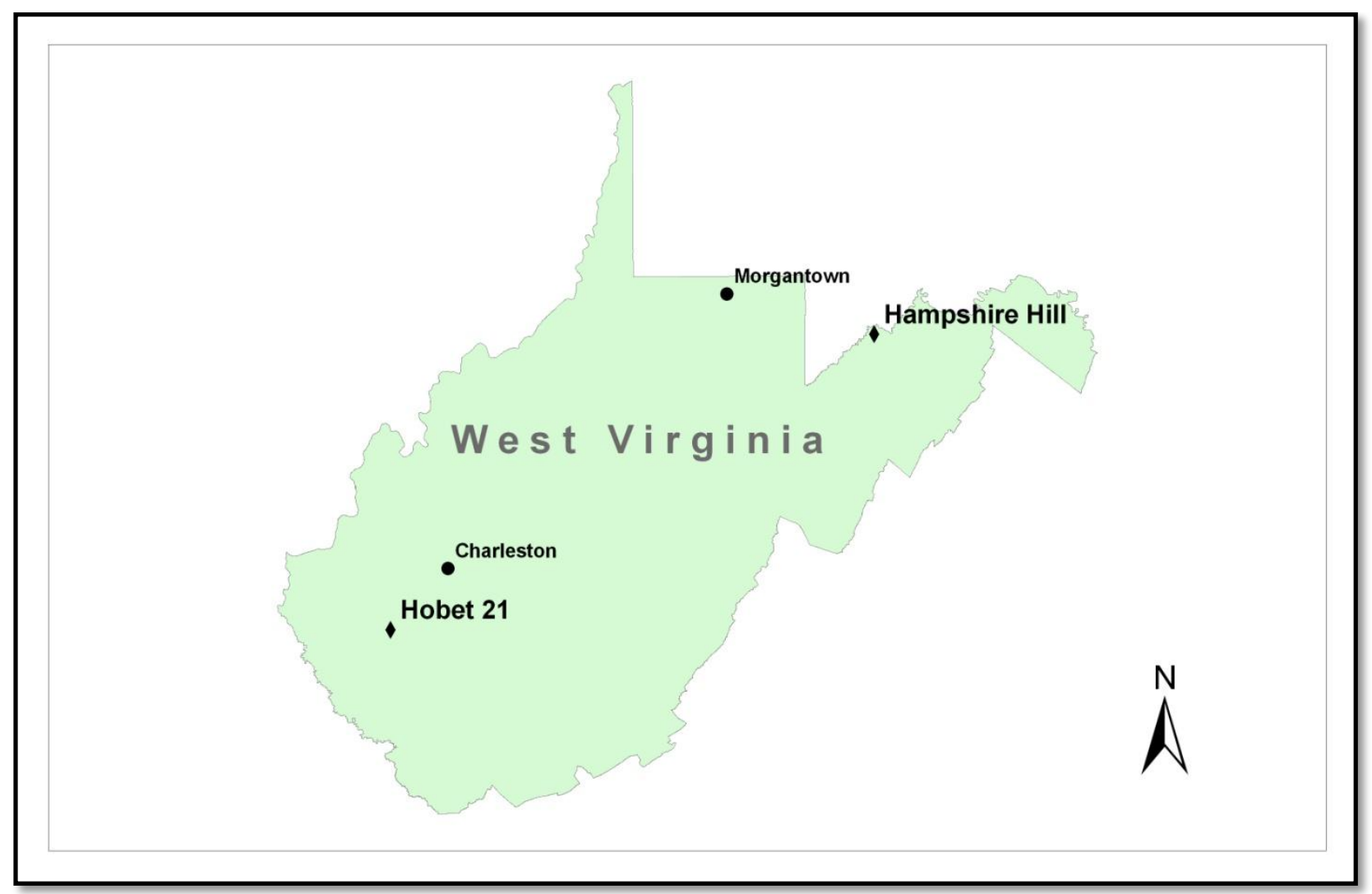




\subsubsection{Experimental Design}

In 2008 , three commercially available, upland varieties of switchgrass, purchased from Ernst Conservation Seed (Meadville, PA) were planted at Hampshire Hill and Hobet 21 mine sites in a completely randomized design (Table 3.1). The varieties Cave-in-Rock, Carthage, and Shawnee were planted in 0.4-hectare plots replicated three times for a total of nine plots per site. Switchgrass was seeded on all plots at a rate of $11.2 \mathrm{~kg} \mathrm{PLS} \mathrm{ha}^{-1}$ using a hand broadcast seeder. Both sites were also tilled using a small offset disk harrow pulled by a small bulldozer prior to planting (Keene and Skousen, 2009).

Switchgrass sampling was conducted at both sites at six randomly selected points per plot. Specific sampling techniques are discussed in upcoming sections, but all samples for biomass and chemical and physical analysis were taken using the same coordinates. Sampling points within each plot were selected in a previous study (Keene and Skousen, 2009) and recorded using a handheld Global Positioning System (GPS) (GARMIN eTrex Vista H) (Figure 3.2 and 3.3). Sampling point coordinates can be found in Appendix 1. 
Figure 3.2: Site layout of Hampshire Hill showing varieties and sampling points.

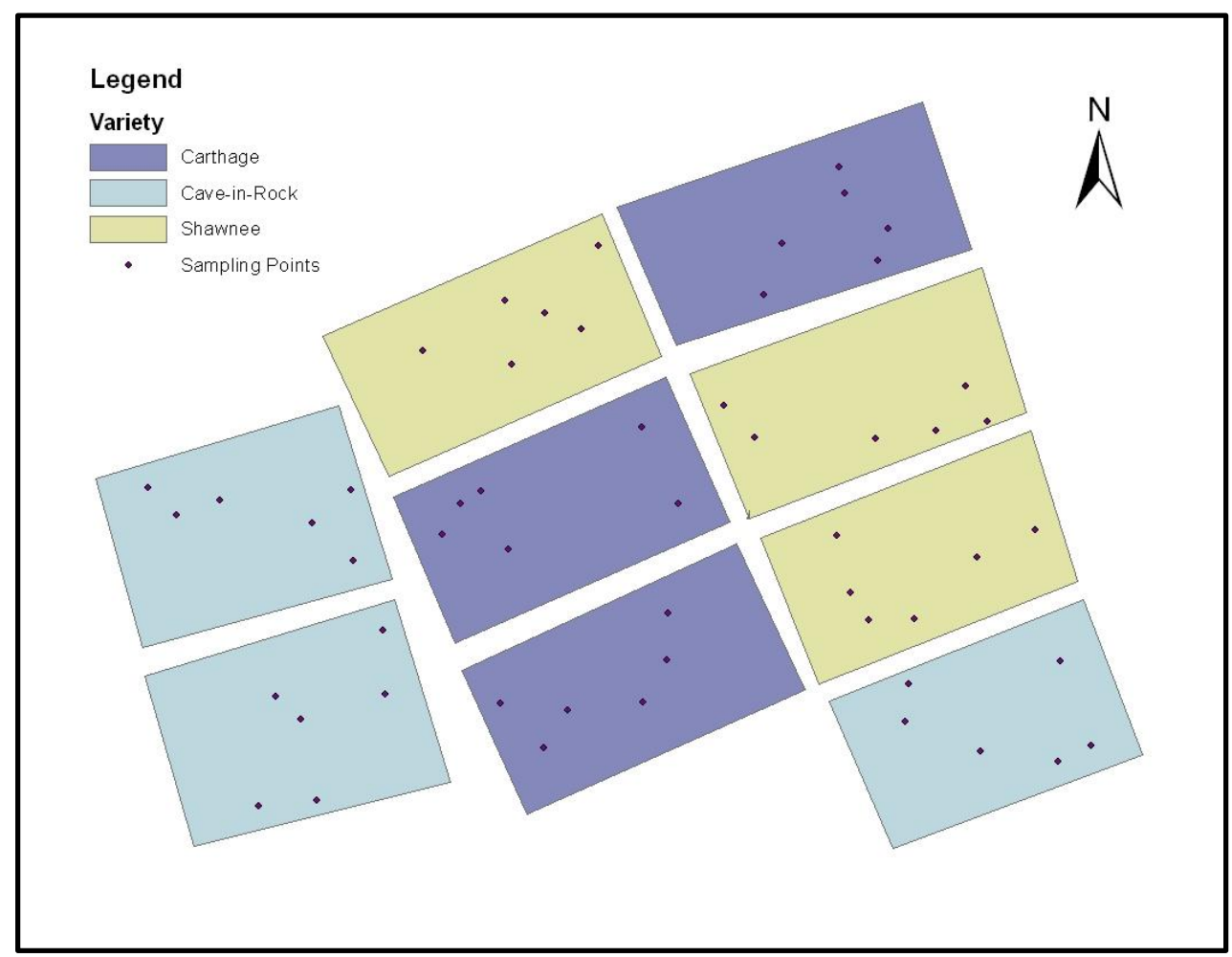


Figure 3.3: Site layout of Hobet 21 showing varieties and sampling points.

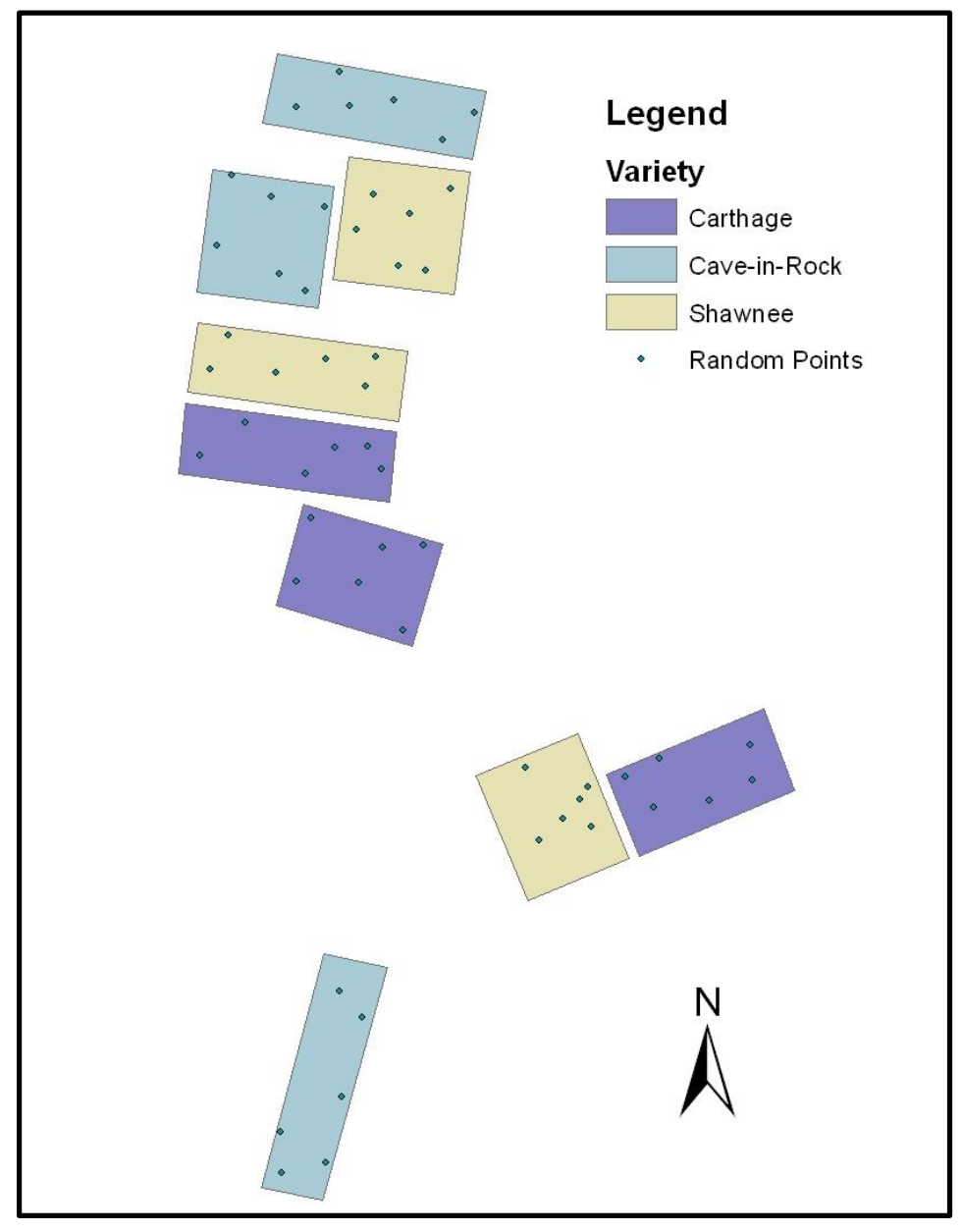

3.2.3. Vegetation Measurement and Analysis

Yield was determined by clipping all switchgrass within a $0.21-\mathrm{m}^{2}$ quadrat at each sampling location within each plot. Aboveground biomass was clipped using garden shears at a stubble height of approximately 5 to $8 \mathrm{~cm}$, which was common to previous studies at these sites. Non-switchgrass material was discarded from the sample. If no switchgrass was found inside the quadrat, a zero was recorded for the sample location. In a critical review of publications examining the biology and agronomy of switchgrass conducted by Parrish and Fike (2005), clipping height or stubble height was one of many management practices summarized. In the 
review, stubble heights ranged from 5 to $30 \mathrm{~cm}$. In general, the review indicated that 1) more biomass was collected when clipped to a lower stubble height, 2) more regrowth in multiple harvest systems occurred when first-cut stubble height was higher, and 3) clipping at a lower stubble height typically resulted in better stand persistence. For this experiment, samples within the $0.21-\mathrm{m}^{2}$ quadrat were clipped at approximately $5-8 \mathrm{~cm}$ with the goal to collect the maximum amount of biomass without clipping at shorter heights. The clipped samples were then oven dried at $60^{\circ} \mathrm{C}$ to a constant weight and weighed to determine dry matter weight. For the purpose of this document, the term yield is described as above ground switchgrass biomass clipped at a stubble height of 5 to $8 \mathrm{~cm}$, dried at $60^{\circ} \mathrm{C}$ to a constant weight and weighed to determine dry matter weight.

The switchgrass weights in these plots were used to assess the main effects of switchgrass variety, site, and year, as well as to determine interactions among the main effects. Switchgrass variety and site were considered fixed effects, while years were considered a fixed repeated measure. Yield data from 2009, 2010, and 2011 were analyzed using repeated measures factorial analysis of variance (ANOVA) by SAS (2008). Yield was the dependent, response variable. Statistically significance was based on a p-value of 0.05 .

Various possibilities were explored for the covariance structure of the mixed model procedure. The same predictor variables were used to select among four covariance structures: Compound Symmetry, Unstructured, Autoregressive, and Toeplitz. The unstructured covariance structure best fit the data, and was therefore selected for the model. The different model criteria used in the selection process were: Akaike Information Criterion (AIC), AIC corrected (AICc), and Bayesian Information Criterion (BIC). Yield data analysis was completed using square root 
transformed data to meet the assumption that the data are normally distributed. The method of data transformation was based on the Box-Cox method (Faraway, 2004).

\subsubsection{Soil Sampling}

Soil samples were collected at both sites annually during the growing season and analyzed to determine soil chemical and physical properties. Soil samples were collected by taking a shovel slice from each of the six sample locations within each plot to a depth of approximately $15 \mathrm{~cm}$.

Once collected, all samples were air dried, weighed, and sieved with a US \#10 2-mm sieve. The fine fraction (sample fraction $<2 \mathrm{~mm}$ ) was collected and used for chemical analysis. During the sieving process, effort was made to break most soil clods by hand or using a hammer in order to ensure the material in the clods was accounted for in the fine fraction. The rock fraction (>2 mm) was collected, washed through a US \#10 2-mm sieve, air dried and reweighed to determine the portion of the sample composed of rock-sized fragments. The washing process breaks apart any remaining soil clods and removes excess fine materials attached to rocks. Percent rock fragments were calculated for each sample by dividing the weight of the rocks by the total weight of the sample and multiplying by $100 \%$.

\subsubsection{Soil Chemical Measurement and Analysis}

All soil chemical analysis were completed using the fine portion of each soil sample, which was analyzed for $\mathrm{pH}$, electrical conductivity (EC) in microSiemens per $\mathrm{cm}(\mu \mathrm{S} / \mathrm{cm})$, and available nutrients. To determine $\mathrm{pH}, 5 \mathrm{~g}$ of soil were combined with $5 \mathrm{~mL}$ of distilled deionized (DDI) water. The mixture was placed on a reciprocating shaker table and mixed for 15 minutes, then allowed to equilibrate for at least 1 hour. A Mettler Toledo SevenEasy pH Meter was used to take the $\mathrm{pH}$ readings. EC was determined by combining $5 \mathrm{~g}$ of soil with $10 \mathrm{~mL}$ DDI 
water. The mixture was placed on a reciprocating shaker table and mixed for 15 minutes, then allowed to equilibrate for at least 1 hour. A Fisher Scientific Accumet Excel (XL60) Dual Channel $\mathrm{pH} / \mathrm{Ion} /$ Conductivity/DO Meter was used to take EC readings.

Mehlich 1 solution, also referred to as Dilute Double Acid solution, composed of 0.0025 $\mathrm{N} \mathrm{H}_{2} \mathrm{~S}_{4}+0.05 \mathrm{~N} \mathrm{HCl}$, was used to extract available elements from the soil (Wolf and Beegle, 1995). For the extraction, $25 \mathrm{~mL}$ of the Mehlich 1 solution was added to $5 \mathrm{~g}$ of soil, mixed on a reciprocating shaker for 5 minutes, then allowed to equilibrate. The samples were then filtered through Fisher Scientific Q5 Filter Paper. Using an inductively coupled plasma emission spectrometer (Optima 2100 DV, Perkin Elmer Corporation, Norwalk, CT), the following elements were determined: $\mathrm{Al}, \mathrm{Fe}, \mathrm{Mn}, \mathrm{Mg}, \mathrm{Ca}, \mathrm{K}, \mathrm{P}, \mathrm{Ni}, \mathrm{Cu}$, and $\mathrm{Zn}$.

Soil chemical and physical data were analyzed using principal components analysis (PCA) in R (R Core Team, 2012). Soil chemical and physical data included the following: proportion fine-sized particles (<2mm) (fines), $\mathrm{pH}$, electrical conductivity (EC), $\mathrm{Al}, \mathrm{Fe}, \mathrm{Mn}, \mathrm{Mg}$, $\mathrm{Ca}, \mathrm{K}, \mathrm{P}, \mathrm{Ni}, \mathrm{Cu}$, and $\mathrm{Zn}$. The purpose of using PCA was to represent the thirteen chemical variables and percent fines in a composite set of variables to explain some of the variation among the two sites. Prior to analysis, the data was standardized by site and correlated variables were removed. Trace metals, $\mathrm{Cu}, \mathrm{Zn}$ and $\mathrm{Ni}$ were highly correlated; therefore $\mathrm{Cu}$ and $\mathrm{Ni}$ were excluded from the analysis. PCA in R was conducted on the new data set, which included the remaining chemical variables, fines, site, plot, variety and square root of yield. Principal components with eigenvalues greater than 1.0 were kept for further analysis; all others were discarded. 


\subsubsection{Soil Particle Size Analysis}

Soil particle size of each site was determined using the pipette method (Gee and Bauder, 1986). Ten samples were randomly selected from each site for this analysis. Approximately 40 $\mathrm{g}$ of soil was measured into $300 \mathrm{~mL}$ fleakers and then $10 \mathrm{~mL}$ of hydrogen peroxide (30 wt. \%) was added to begin removal of organic matter. Addition of hydrogen peroxide caused samples to bubble and froth vigorously. Once bubbling calmed, fleakers were placed on a hot plate set at approximately $60-70^{\circ} \mathrm{C}$. Additional hydrogen peroxide was added $5 \mathrm{ml}$ at a time while the fleaker remained on the hot plate and the reaction was allowed to proceed until most of the organic matter was burned, indicated by lack of bubbling.

Once organic matter was burned off, samples were then oven dried at $105^{\circ} \mathrm{C}$ for 24 to 48 hrs. Once completely dried, samples were removed, allowed to cool and weighed to record starting soil weight. A solution of $10 \mathrm{~mL}$ of sodium hexametaphosphate (HMP) at a concentration of $50 \mathrm{~g} \mathrm{~L}^{-1}$ was added to each fleaker as a dispersing agent. Using approximately 100 to $150 \mathrm{ml}$ DDI water, all of the contents in the fleaker were carefully transferred to a stainless steel milkshake container. Each sample was mixed on a mechanical milkshake mixer for approximately $5 \mathrm{~min}$. Samples were then washed from the stainless container into $1 \mathrm{~L}$ volumetric settling columns and filled to capacity with DDI water. Samples were mixed endover-end for $1 \mathrm{~min}$ and then allowed to settle for a specific amount of time. Settling time, which is based on the constant settling rate of soil particles based on size and temperature as predicted by Stoke's Law, was based on the temperature of a column filled with DDI water.

After settling, the top $25 \mathrm{ml}$ of liquid from each settling column were pipetted into a preweighed beaker to measure amount of suspended clay particles. The remaining contents in the settling column were emptied through a US \# $270(.053 \mathrm{~mm})$ sieve to collect sand-sized 
particles. The sand in the sieve was washed with tap water to remove all silt. Washing continued until water running through the sieve was completely clear. Once washed, the sand was transferred to a pre-weighed beaker. Beakers containing clay and sand were oven dried at $105^{\circ} \mathrm{C}$ for 24 to 48 hrs. Dried beakers were reweighed to determine the percent sand and clay of the total soil sample. The amount clay was calculated using the following equation: $w V / v$; where $w$ $=$ dry weight of sample $(\mathrm{g}), v=$ volume of pipette $(\mathrm{mL})$, and $V=$ total volume of suspension $(\mathrm{mL})$. Percent silt-sized particles were determined as the difference between the sand and clay from the total soil sample.

\subsection{Results and Discussion}

\subsubsection{Vegetation Measurement}

Results of the repeated measures ANOVA analysis were that yield was significantly impacted by year, site, and variety at p-value $<0.05$ (Tables 3.1 and 3.2). Additionally, the results determined that there was a site*variety interaction, but variety*year and site*variety interactions were not significant at $\mathrm{p}$-value $<0.05$.

Table 3.1: Repeated measures ANOVA table with yield as the response variable.

\begin{tabular}{lllll}
\hline Effect & DF & Den DF & F Value & Pr $>\mathbf{F}$ \\
\hline Site & 1 & 25.5 & 321.50 & $<0.0001^{*}$ \\
Variety & 2 & 25.5 & 7.66 & $0.0025^{*}$ \\
Year & 2 & 23.8 & 43.60 & $<0.0001^{*}$ \\
Site*variety & 2 & 27.2 & 16.35 & $<0.0001^{*}$ \\
Variety*year & 4 & 26.1 & 0.77 & 0.5558 \\
Site*year & 2 & 23.8 & 1.92 & 0.1680 \\
\hline
\end{tabular}

\footnotetext{
*Indicates significance at a $\mathrm{p}=0.05$ level.
} 
Table 3.2: Repeated measures ANOVA results and mean yields for Switchgrass grown on reclaimed surface mines during the second, third and fourth years of growth.

\begin{tabular}{|c|c|c|c|c|c|c|}
\hline \multirow[t]{2}{*}{ Effect } & & $\mathbf{P}>\mathbf{F}^{*}$ & Mean & Mean & $\mathbf{S D}+$ & $\mathrm{CV} \pm$ \\
\hline & & & $\mathrm{kg} \mathrm{ha}^{-1}$ & -----Squar & $\operatorname{loot} \mathrm{Yi}_{\mathrm{i}}$ & Data*--. \\
\hline \multirow[t]{3}{*}{ Site } & & $<.0001$ & & & & \\
\hline & Hampshire Hill & & $5760^{A}$ & $25.5^{\mathrm{A}}$ & 17.5 & 0.69 \\
\hline & Hobet 21 & & $\mathbf{8 0 3}^{B}$ & $73.9^{\mathrm{B}}$ & 12.6 & 0.17 \\
\hline \multirow[t]{4}{*}{ Variety } & & .0025 & & & & \\
\hline & Cave-in-Rock & & $4298^{A}$ & $55.9^{\mathrm{A}}$ & 35.2 & 0.63 \\
\hline & Carthage & & $2479^{B}$ & $43.0^{\mathrm{B}}$ & 25.8 & 0.60 \\
\hline & Shawnee & & $3069^{A}$ & $50.2^{\mathrm{A}}$ & 24.2 & 0.48 \\
\hline \multirow[t]{4}{*}{ Year } & & $<.0001$ & & & & \\
\hline & 2009 & & $2359^{\mathrm{C}}$ & $39.7^{\mathrm{C}}$ & 28.8 & 0.73 \\
\hline & 2010 & & $4457^{\mathrm{A}}$ & $60.5^{\mathrm{A}}$ & 29.0 & 0.48 \\
\hline & 2011 & & $3029^{B}$ & $48.9^{\mathrm{B}}$ & 25.9 & 0.53 \\
\hline \multirow[t]{9}{*}{ Site*Variety } & & $<.0001$ & & & & \\
\hline & Hobet 21 & & & & & \\
\hline & Cave-in-Rock & & $743^{B}$ & $23.7^{\mathrm{B}}$ & 14.4 & 0.61 \\
\hline & Carthage & & $581^{B}$ & $22.3^{\mathrm{B}}$ & 9.6 & 0.43 \\
\hline & Shawnee & & $1086^{A}$ & $30.5^{\mathrm{A}}$ & 13.3 & 0.44 \\
\hline & Hampshire Hill & & & & & \\
\hline & Cave-in-Rock & & $7853^{\mathrm{A}}$ & $88.2^{\mathrm{A}}$ & 8.7 & 0.10 \\
\hline & Carthage & & $4376^{B}$ & $63.7^{\mathrm{B}}$ & 19.0 & 0.30 \\
\hline & Shawnee & & $5051^{B}$ & $69.9^{\mathrm{B}}$ & 13.8 & 0.20 \\
\hline \multirow{13}{*}{$\begin{array}{l}\text { Variety* } \\
\text { Year }\end{array}$} & & NS & & & & \\
\hline & 2009 & & & & & \\
\hline & Cave in Rock & & 3275 & 44.3 & 39.7 & 0.90 \\
\hline & Carthage & & 1859 & 35.2 & 27.2 & 0.77 \\
\hline & Shawnee & & 1944 & 39.5 & 21.4 & 0.54 \\
\hline & 2010 & & & & & \\
\hline & Cave in Rock & & 5140 & 63.8 & 35.8 & 0.56 \\
\hline & Carthage & & 3640 & 53.7 & 30.1 & 0.56 \\
\hline & Shawnee & & 4592 & 64.0 & 24.3 & 0.38 \\
\hline & 2011 & & & & & \\
\hline & Cave in Rock & & 4479 & 59.8 & 33.0 & 0.55 \\
\hline & Carthage & & 1938 & 40.1 & 19.8 & 0.49 \\
\hline & Shawnee & & 2669 & 46.9 & 23.7 & 0.50 \\
\hline
\end{tabular}

Site*Year

Hampshire Hill

2009

NS

2010

4502

7668

2011

5112

66.1

12.0

0.18

87.2

8.7

0.10

Hobet 21

68.4

22.0

0.32 


\begin{tabular}{rcccc}
2009 & 217 & 13.2 & 6.9 & 0.52 \\
2010 & 1247 & 33.8 & 10.8 & 0.32 \\
2011 & 946 & 29.5 & 9.4 & 0.32 \\
\hline
\end{tabular}

*Statistics and p-values determined using square root transformed data.

$\uparrow$ Standard Deviation

\pm Coefficient of Variation

The significant site effect indicated a difference between the ability of the Hampshire Hill mine site to produce switchgrass compared to the Hobet 21 mine site. Across three years of data and variety, the Hampshire Hill site produced $5760 \mathrm{~kg}$ (ha-yr) ${ }^{-1}$ compared to $803 \mathrm{~kg}$ (ha-yr) ${ }^{-1}$ at Hobet 21, reporting original, untransformed data (Table 3.2). This difference in yield is due to the difference in reclamation practices prior to establishment. The application of topsoil and lime-treated sludge as well as the additional years of weathering at Hampshire Hill proved to be a better soil medium for switchgrass growth compared to the unweathered overburden material placed at the surface at Hobet 21. Although much higher than the yields recorded at Hobet 21, Hampshire Hill yields are still not comparable to switchgrass yields from normal agronomic yields recorded in research literature, which often reached 10,000 to $15,000 \mathrm{~kg}$ (ha-yr) ${ }^{-1}$ (Fike et al., 2006a; Fike et al.2006b; Fransen, 2009; Lemus et al., 2002; Mclaughlin and Kszoz, 2005; Sanderson et al., 1996).

The main effect, variety, was significant at $\mathrm{p}<0.01$ with Carthage appearing to be the worst performer when comparing average yields across site and year (Tables 3.2 and 3.3). No significant difference was found when comparing Shawnee to Cave-in-Rock. Square root transformed yield data were used for this analysis, however in Table 3.3 and all other tables, untransformed yield data were reported for the ease of interpretability. The data in Table 3.3 may seem misleading in that Cave-in-Rock produced over $1200 \mathrm{~kg} \mathrm{ha}^{-1}$ more yield compared to Shawnee, yet no significant difference was determined. Square root transformed yield data were 
55.9, 43.0 and 50.2 for Cave-in-Rock, Carthage and Shawnee, respectively. Furthermore, determination of no significant difference between Cave-in-Rock and Shawnee may be due to the high variance among samples as well as some variation in how varieties produced at the two sites. Many samples collected from plots planted with Shawnee and Cave-in-Rock contained relatively high yields and other collection samples were very small or even zero. A site*variety interaction (Tables 3.1 and 3.2) confirms that variety rankings differed between the two sites.

Cave-in-Rock outperformed Carthage and Shawnee, and no significant difference was found between Carthage and Shawnee at the Hampshire Hill mine site (Table 3.3). Hobet 21 differed from Hampshire Hill in that Shawnee was the top performer and Cave-in-Rock and Carthage showed no significant difference in yield (Table 3.3). These findings are interesting in that Shawnee is an improved variety of Cave-in-Rock and performed better at a lower fertility site.

Table 3.3: Switchgrass yield by variety and site averaged across years.

\begin{tabular}{|c|c|c|c|}
\hline Variety & Hampshire Hill $\uparrow$ & Hobet $21 \dagger$ & $\begin{array}{l}\text { Averaged across } \\
\text { sites and years }\end{array}$ \\
\hline & 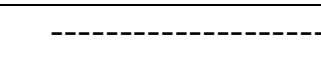 & --kg ha ${ }^{-1}--\cdot-$ & ----------------- \\
\hline Cave-in-Rock & $7853 *$ & $743^{\mathrm{B}}$ & 4298 * \\
\hline Carthage & $4377^{\mathrm{B}}$ & $581^{\text {B }}$ & $2479^{\mathrm{B}}$ \\
\hline Shawnee & $5051^{\mathrm{B}}$ & $1086^{\mathrm{A}}$ & $3069^{\mathrm{A}}$ \\
\hline
\end{tabular}

$\dagger$ Variety contrasts were based on square root transformed data

* Different letters within a column denote significance at $\mathrm{p}<0.05$ level

Significance associated with the main effect, year, indicates that yield changed from year to year from 2009 to 2011, which was expected. Untransformed yield data, averaged across site 
and variety, increased from $2359 \mathrm{~kg} \mathrm{ha}^{-1}$ in 2009 to $4459 \mathrm{~kg} \mathrm{ha}^{-1}$ in 2010 , but decreased to 3029 $\mathrm{kg} \mathrm{ha}^{-1}$ in 2011 (Table 3.2 and 3.4). Absence of a year*site interaction $(\mathrm{p}=0.17)$ indicates that both the Hampshire Hill and Hobet sites produced similar yield over time. A decline in yield from 2010 to 2011 was not expected. In a study conducted by Kering et al. (2011), yield did not differ from the second to third year of production and a decline in yield is not common unless growth is hindered by a natural phenomenon such as climate. During the period of our study, no major climate changes from normal conditions took place, such as extended droughts, periods of excessive rainfall or other uncharacteristic climate events.

Table 3.4: Switchgrass yield by year averaged across sites and varieties.

\begin{tabular}{ll}
\hline Year & Yield $\left(\mathbf{k g ~ h a}^{-1}\right) \dagger$ \\
\hline 2009 & $2359^{\text {* }}$ \\
2010 & $4457^{\mathrm{B}}$ \\
2011 & $3029^{\mathrm{C}}$ \\
\hline
\end{tabular}

$\dagger$ Year contrasts were based on square root transformed data

*Different letters within a column denote significance at $\mathrm{p}<0.05$ level

When observing monthly climate data collected at weather stations near the Hobet 21 and Hampshire Hill sites from the National Oceanic and Atmospheric Administration (NOAA), no major discrepancies between years are observed for total precipitation or average temperature. A weather station near the Hampshire Hill site in Keyser, WV, reported average monthly temperatures in 2011 followed similar patterns to 2009 and 2010. Little information can be ascertained when examining total monthly precipitation from the same weather station except that heavy rainfall in April and May could have benefited cool-season weed species competing with the switchgrass crop at Hampshire Hill. However, no other data were collected as supporting evidence. Weather data collected at a weather station in Madison, WV, near the 
Hobet 21 site, offered little explanation to the loss in yield in 2011. Total monthly precipitation and temperature in 2011 were comparable to records for 2009 and 2010 (Figure 3.4).

The optimal air temperature for switchgrass is between 26 and $32^{\circ} \mathrm{C}$ (Volence and Nelson, 2003), which is a range encompassing summers in West Virginia. In a study compiling climate information from over 1000 studies across 39 states in the U.S., Wullschleger et al. (2010) predicted that switchgrass can produce highest yields in areas of the U.S. with moderate temperature and moderate rainfall, assuming annual application of $100 \mathrm{~kg} \mathrm{~N} \mathrm{ha}^{-1}$. West Virginia is located in the area predicted by Wullschleger et al. as the highest yielding area, however no $\mathrm{N}$ was applied in our study. 
Figure 3.4: Precipitation and temperature data from NOAA for Keyser, WV and Madison, WV weather stations.
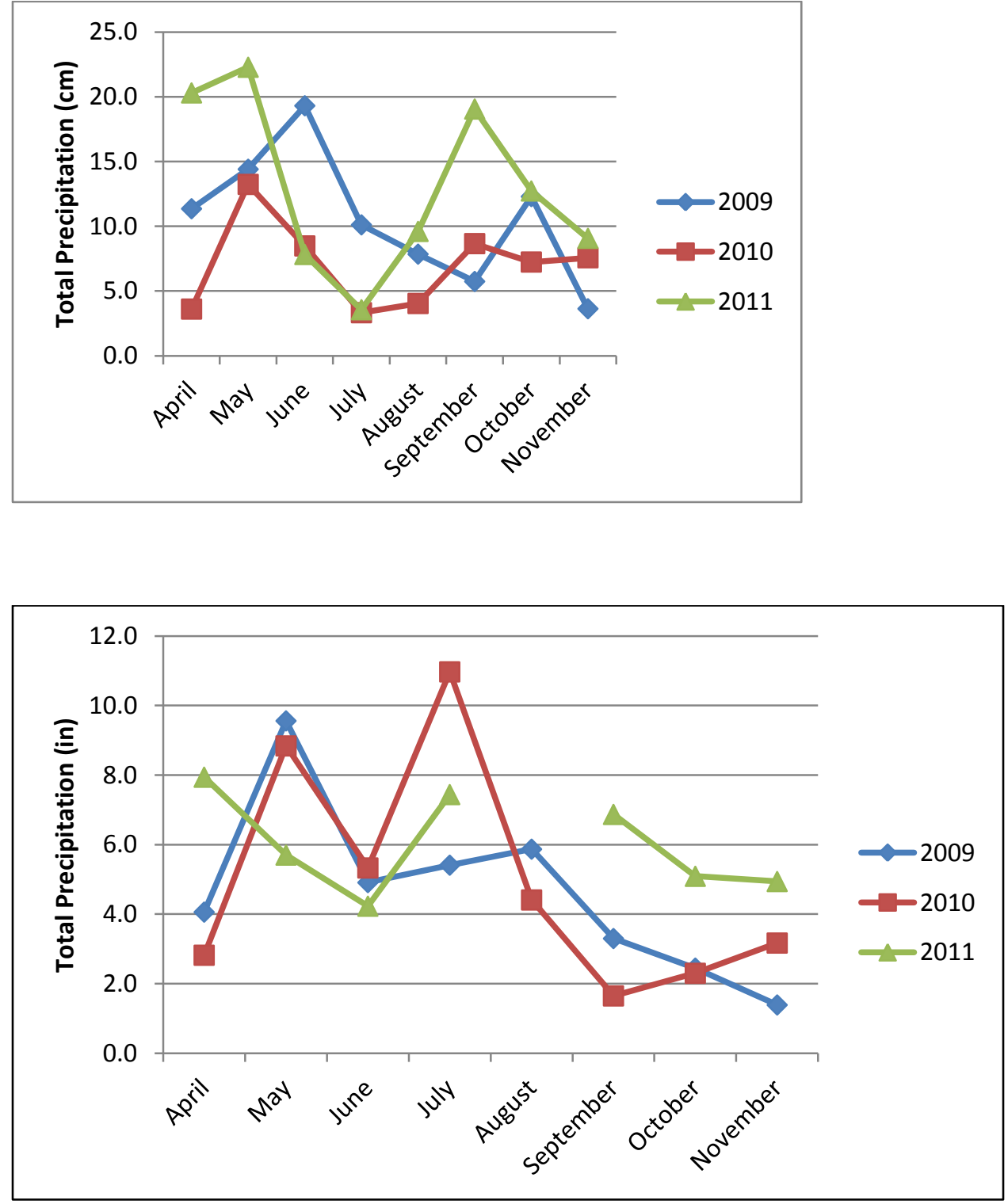

Top - Keyser, WV weather station; total monthly precipitation $(\mathrm{cm})$ Bottom - Madison, WV weather station; total monthly precipitation $(\mathrm{cm})^{*}$ *Insufficient or partial data was reported by NOAA for the month of August 2011. Ten or more daily values were missing therefore no data were recorded. 

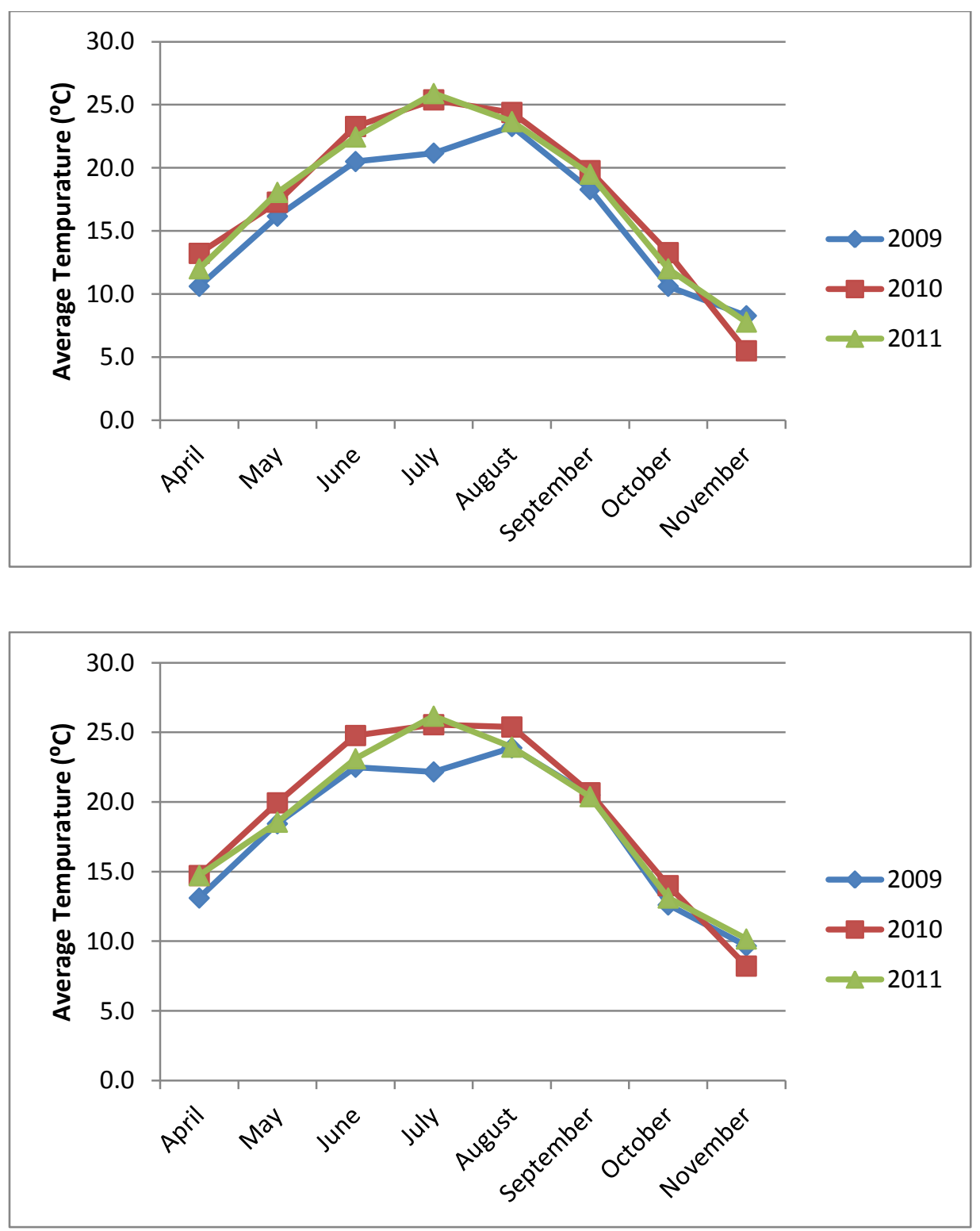

Top - Keyser, WV weather station; average monthly temperature $\left({ }^{\circ} \mathrm{C}\right)$ Bottom - Madison, WV weather station; average monthly temperature $\left({ }^{\circ} \mathrm{C}\right)$

It should be noted that neither site received any amendments during the three-year study. A long-term study in Texas saw a decline in switchgrass yields over the years when no $\mathrm{N}$ was applied (Muir et al., 2001). Conversely, Balasko et al. (1984) grew productive stands for three years in West Virginia with no amendments on what was considered marginal crop land. In the three-year study, yields ranged from 6,600 to $8,900 \mathrm{~kg}$ (ha-yr) ${ }^{-1}$ (Balasko et al. 1984). While 
annual application of amendments is not uncommon in most agronomic and farm production systems, most mine operators prefer to minimize costs associated with reclamation especially beyond the year reclamation took place. For this reason alone, further exploration into this area could benefit mine operators who hope to use switchgrass as a reclamation species.

It is worth noting that a rotary mower was used to mow all plots at Hampshire Hill in spring 2011. All cut debris was left on the surface. Mowing switchgrass after the third growing season should not have had a detrimental effect on total yield at Hampshire Hill and rainfall was above 2009 and 2010 monthly averages for April and May. We did observe that the heavy growth that was cut laid on the surface and may have had a negative impact and hindered regrowth of switchgrass in 2011. If this material had been removed from the site as in a conventional haying operation, the heavy cover of debris and dead material on the surface would not have hampered the regrowth of switchgrass at Hampshire Hill. Mowing at Hampshire Hill does not alone give inference into the total decline of yield from 2010 to 2011. Further monitoring may give an indication of the problem for decreasing yield.

\subsubsection{Soil Chemical and Physical Properties}

PCA was used to examine soil physical and chemical properties at the Hampshire Hill and Hobet 21 sites. The first three principal components (PC) were interpreted from the PCA and explained 78.8 percent of the variability within the original data set. PC1, PC2 and PC3 had eigenvalues of $4.58,3.45$ and 1.43 , respectively. Factor loadings, or eigenvectors, within each PC were examined to determine how the original variables related to each PC. For this study, factor loadings with an absolute value greater than or equal to 0.80 were considered for further examination. The micronutrients, $\mathrm{Al}, \mathrm{Mn}$ and $\mathrm{Zn}$, and the macronutrient $\mathrm{P}$ loaded highly in PC1. The micronutrient Fe loaded at 0.785 and was included in the analysis because of its proximity to 
the 0.80 threshold and its relevance in mine reclamation. $\mathrm{PC} 2$ was influenced by $\mathrm{pH}$ and $\mathrm{Ca}$, and PC3 mainly related to percent fines in the soil (Table 3.5).

Table 3.5: Eigenvectors by Principal Components.

\begin{tabular}{ccc}
\hline PC1 & PC2 & PC3 \\
\hline Zn $(0.883)$ & $\mathrm{pH}(0.924)$ & \% Fines $(-0.900)$ \\
$\mathrm{Mn}(0.875)$ & $\mathrm{Ca}(0.876)$ & \\
$\mathrm{Al}(0.858)$ & & \\
$\mathrm{P}(0.803)$ & & \\
$\mathrm{Fe}(0.785)$ & & \\
\hline
\end{tabular}

A graphical display of the nine plots at each site using PC1 and PC2 as axes shows separation by site (Figure 3.5). The orthogonal relationship between Hampshire Hill and Hobet 21 is supported when examining site means of each of the soil chemical and physical variables which loaded highly (greater than or equal to 0.80 ) within their respective PC (Table 3.7). In the case of PC1, site means of $\mathrm{Zn}, \mathrm{Mn}$, and $\mathrm{Al}$ are greater at Hampshire Hill compared to Hobet 21; while P and Fe are much lower at Hampshire Hill. PC2 seemed to separate Hampshire Hill from Hobet 21 by differences in soil $\mathrm{pH}$ and $\mathrm{Ca}$ concentrations. Hampshire Hill's mean soil pH was 7.4 and closer to neutral compared to Hobet 21 with an alkaline $\mathrm{pH}$ of 8.1. Hampshire Hill also had higher extractable Ca than Hobet 21. PC3, although not used for the graphical display, recognized a difference in percent fines between the sites. Hobet 21, more recently reclaimed than Hampshire Hill, had 55.1\% fines and Hampshire Hill had 74.4\% fines. 
Table 3.6: Site means of all soil chemical and physical properties.

\begin{tabular}{lcccc}
\hline & \multicolumn{2}{c}{ Hobet 21} & \multicolumn{2}{c}{ Hampshire Hill } \\
\cline { 2 - 5 } & Mean & COV $\ddagger$ & Mean & COV $\ddagger$ \\
\hline proportion fines $\dagger$ & 0.55 & 0.21 & 0.74 & 0.14 \\
$\mathbf{p H}$ & 8.08 & 0.04 & 7.43 & 0.03 \\
$\mathbf{E C}$ 口 & 109.13 & 0.27 & 421.39 & 0.25 \\
$\mathbf{A l}^{*}$ & 31.41 & 0.23 & 97.50 & 0.72 \\
$\mathbf{F e}^{*}$ & 51.96 & 0.53 & 21.87 & 1.30 \\
$\mathbf{M n}^{*}$ & 28.68 & 0.48 & 48.65 & 0.35 \\
$\mathbf{M g}^{\times}$ & 1.30 & 0.25 & 1.33 & 0.26 \\
$\mathbf{C a}^{\times}$ & 2.04 & 0.55 & 11.34 & 0.34 \\
$\mathbf{K}^{\times}$ & 0.10 & 0.28 & 0.21 & 0.41 \\
$\mathbf{N a}^{\times}$ & 0.03 & 0.56 & 0.03 & 0.29 \\
$\mathbf{P}^{*}$ & 50.01 & 0.39 & 7.99 & 0.67 \\
$\mathbf{N i}^{*}$ & 0.95 & 0.48 & 0.43 & 0.65 \\
$\mathbf{C u}^{*}$ & 1.94 & 0.48 & 1.41 & 1.14 \\
$\mathbf{Z n}^{*}$ & 2.36 & 0.35 & 6.73 & 0.62 \\
\hline
\end{tabular}

*Measured in mg nutrient per $\mathrm{kg}$ of soil.

${ }^{\times}$Measured in cmol charge per $\mathrm{kg}$ of soil.

$\dagger$ Calculated as the proportion of sample $<2 \mathrm{~mm}$ in size.

- Measured in microSiemans

$\uparrow$ Coefficient of Variation

The factor loadings were also examined graphically using a biplot (Figure 3.5). Factor loadings are displayed as arrows and the direction and length of the arrow represents the PC on which the factor loads and the strength with which it loads, respectively. Arrows running horizontally indicate loading on PC1 and arrows running vertically indicate loading on PC2. In this case, $\mathrm{P}, \mathrm{Al}, \mathrm{Mn}$ and $\mathrm{Zn}$ load strongly along the $\mathrm{PC} 1$ axis toward the negative and very slightly toward the positive PC2. A cluster of Hampshire Hill plots are also located in this vicinity of the graphical display. Similarly, soil $\mathrm{pH}$ and Ca load strongly along PC2 where several Hobet 21 plots also reside on the graph. 
Figure 3.5: Biplot displaying sites and factor loadings of soil chemical and physical variables along Principal Components 1 and 2.

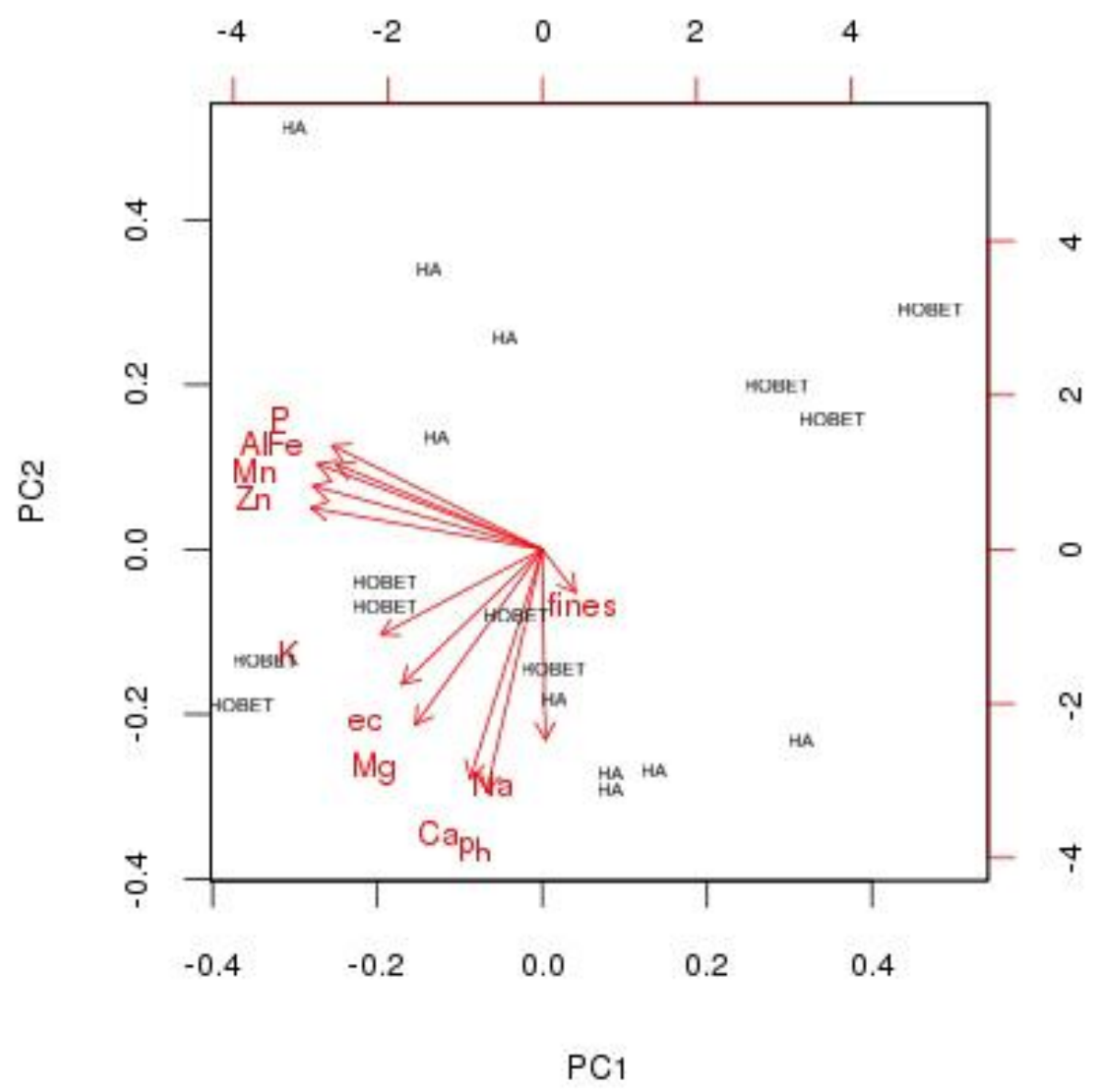

\subsubsection{Soil Particle Size Analysis}

Results of the soil particle size analysis further confirm a difference in the Hampshire Hill and Hobet 21 sites. Results indicated that the textural class best suited to describe Hampshire Hill is loam and Hobet 21 is a sandy loam (Table 3.8). The 10 samples from Hampshire Hill used for the analysis had an average percent sand of 42.3 , an average percent silt of 47.0, and average percent clay of 10.8. Hobet 21 showed slightly higher sand content when 
compared to Hampshire Hill. The samples used for particle size analysis from Hobet 21 had an average percent sand of 63.5, an average percent silt of 26.7, and average percent clay of 9.8 .

The results of the soil particle size analysis coincide with results from determination of percent fine and rock material. Samples collected in 2011 from Hampshire Hill averaged 74.4\% fine-sized material (material sized $<2 \mathrm{~mm}$ ) and samples collected from Hobet 21 averaged $55.1 \%$. Results of soil particle size analysis and determination of percent fine material would indicate that Hobet 21 is a rockier and coarser-textured soil compared to Hampshire Hill, which could correlate to differences in water holding capacity and fertility between sites.

Table 3.7: Soil particle size distribution by site plus or minus one standard deviation.

\begin{tabular}{lccc}
\hline & \% Sand & \% Silt & \% Clay \\
\hline Hampshire Hill & 42.3 & 47.0 & 10.8 \\
& $( \pm 7.9)$ & $( \pm 6.8)$ & $( \pm 8.6)$ \\
Hobet 21 & 63.5 & 26.7 & 9.8 \\
& $( \pm 8.8)$ & $( \pm 7.1)$ & $( \pm 1.9)$ \\
\hline
\end{tabular}

\subsection{Summary and Conclusions}

Significance of the main effects of site and variety showed a clear difference in the two sites' ability to produce switchgrass and that certain varieties may produce better yields when grown on reclaimed surface mines. The three upland varieties used in this study are common and commercially available, but Cave-in-Rock produced the highest yield at the more fertile Hampshire Hill site. Shawnee, an improved variety of Cave-in-Rock, out preformed the other varieties at the less fertile and coarser-textured Hobet 21 site. The Carthage variety was the worst performer at both sites and therefore reclamation with the variety Carthage is not recommended in West Virginia based on this study. The resulting yields of Shawnee or Cave-in-Rock on these 
sites are based on soil properties and fertility and other site characteristics. Further research in this area could be very beneficial.

The significant effect associated with site probably was due to the differing reclamation procedures and management prior to switchgrass establishment as well as the geographical difference of the sites. As mentioned, the mine soil at Hobet 21 was composed of broken rocks from the overburden that had been recently placed there with no time for weathering. Because of the large amount of rock fragments and hence lower fine material as well as results of chemical analysis, it appeared that these soils had poorer fertility and lower water-holding capacity than soils with more fine-sized material in the soil. Results of the soil particle size analysis confirmed a difference in texture of the two sites. Hobet 21 is best described as a sandy loam while Hampshire Hill, which had less sand and more silt, was described as a loam. Hampshire Hill had more fine material because it was topsoiled with the original salvaged topsoil from the site and also was amended with organic material in the form of paper mill and sewage sludge from the municipal wastewater treatment plant. The mine soil at Hampshire Hill was fertile and fine textured, which created a more ideal condition for plant growth. Yield differences between Hobet and Hampshire Hill can be traced to these mine soil property differences.

Less anticipated was the decline of yield between the years 2010 and 2011. From 2009 to 2010, biomass yields increased at both sites, however total biomass yield decreased in 2011 compared to 2010. Besides no annual application of $\mathrm{N}$ amendments, discussed above, another answer for the decline in yield was thought to be climate. However, no significant or drastic climatic events occurred during the period of this study. Declines in yield were probably associated with cutting the biomass at Hampshire Hill in the spring of 2011 and leaving it on the surface where it hindered subsequent 2011 growth. 
In summary, based on findings from this study, switchgrass is capable of producing satisfactory yields on reclaimed surface mines, but the yields on these surface mines were about $50 \%$ lower than yields obtained on typical agronomic soils in this area $\left(5,000 \mathrm{~kg}\right.$ (ha-yr) ${ }^{-1}$ compared to 10,000 to $12,000 \mathrm{~kg}$ (ha-yr $)^{-1}$ ). Along with site conditions, variety selection can affect yield. Further research may confirm that Shawnee is preferable over Cave-in-Rock on less fertile and coarser-textured mine soils. 


\section{Literature Cited}

Balasko, J. A., D.M. Burner and W.V. Thayne. 1984. Yield and quality of switchgrass grown without soil amendments. Agronomy Journal 76:204-208

Faraway, Julian J. 2004. Linear Models with R. Chapman and Hall/CRC Press, Boca Raton, Florida.

Fike, J.H., D.J. Parrish, D.D. Wolf, J.A. Balasko, J.T. Green, Jr., M. Rasnake and J.H. Reynolds. 2006a. Long-term yield potential of switchgrass-for-biofuel systems. Biomass and Bioenergy 30:198-206.

Fike, J.H., D.J. Parrish, D.D. Wolf, J.A. Balasko, J.T. Green, Jr., M. Rasnake and J.H. Reynolds. 2006b. Switchgrass production for the upper southeastern USA: Influence of cultivar and cutting frequency on biomass yields. Biomass and Bioenergy 30:207-213.

Fransen, S. 2009. Agronomics of switchgrass for biofuel in the west. In Proceedings, 2009 Western Alfalfa and Forage Conference, December 2-4, 2009. Reno, Nevada.

Gee, GW and JW Bauder. 1986. Particle-size analysis. p. 383-411. In A Klute (ed.) Methods of Soil Analysis, Part 1. Physical and Mineralogical Methods. Agronomy Monograph No. 9 (2ed). American Society of Agronomy/Soil Science Society of America, Madison, WI

Keene, T. and J. Skousen. 2009. Switchgrass production potential on reclaimed surface mines in West Virginia. In R.I. Barnhisel (ed.) Proceedings, $26^{\text {th }}$ meeting, American Society for Mining and Reclamation, May 30 -June 5, 2009. Billings, Montana.

Kering, M.K., T.J. Bulter, J.T. Biermacher and J.A. Guretzky. 2011. Biomass yield and nutrient removal rates of perennial grasses under nitrogen fertilization. Bionergy Research 5: 6170.

Lemus, R., E.C. Brummer, K.J. Moore, N.E. Molstad, C.L. Burras and M.F. Barker. 2002. Biomass yield and quality of 20 switchgrass populations in southern Iowa, USA. Biomass and Bioenergy 23:433-442.

McLaughlin, S.B. and L.A. Kszos. 2005. Development of switchgrass (Pancium virgatum) as a bioenergy feedstock in the United States. Biomass and Bioenergy 28:515-535.

Muir, J.P., M.A. Sanderson, W.R. Ocumpaugh, R.M. Jones, R.L Reed (2001)

Biomass production of 'Alamo' switchgrass in response to nitrogen, phosphorus, and row spacing. Agronomy Journal 93, 896-901.

Parrish, D.J. and J.H. Fike. 2005. The biology and agronomy of switchgrass for biofuels. Critical Reviews in Plant Sciences 24:423. 
R Core Team. 2012. R: A language and environment for statistical computing. R Foundation for Statistical Computing, Vienna, Austria. ISBN 3-900051-070. http://www.r-project.org.

Sanderson, M.A., R.L. Reed, S.B. McLaughlin, S.D. Wullshleger, B.V. Conger, D.J. Parrish, D.D. Wolf, C. Taliaferro, A.A. Hopkins, W.R. Ocumpaugh, M.A. Hussey, J.C. Read and C.R. Tisher. 1996. Switchgrass as a Sustainable Bioenergy Crop. Bioresource Technology 56:83-93.

SAS Insititue. 2008. SAS/STAT systems for windows v.9.2. SAS Institute, Cary, N.C.

Volence, J.J. and C.J. Nelson. 2003. Environmental aspects of forage management. p.110. In Barnes, R.F., C.J. Nelson, M. Collinsand K.J. Moore. (ed.) 2003. Forages: An Introduction to Grassland Agriculture. $6^{\text {th }}$ ed. Iowa State Press, Ames

Wolf, A. and Beegle, D. 1995. Recommended soil tests for macronutrients: Phosphorus, Potassium, Calcium and Magnesium. p. 30-38. In Sims, J.T. and A.M. Wolf (ed.). Recommended soil testing procedures for the Northeastern United States. Northeastern Regional Pub. No. 493 (2nd edition). Agricultural Experiment Station Univ. of Delaware, Newark, DE.

Wullschleger, S.D., E.B. Davis, M.E. Borsuk, C.A. Gunderson and L.R. Lynd. 2010. Biomass production in switchgrass across the United States: database description and determinants of yield. Agronomy Journal 102:1158-1168. 


\section{4: Switchgrass establishment methods on newly reclaimed surface mines in West Virginia.}

\subsection{Introduction}

This chapter reports on establishment of switchgrass (Panicum virgatum L.) on two mine sites with operation styles and reclamation practices common to most surface mines in West Virginia. Both sites were planted with one switchgrass variety the same year the area was reclaimed. This study examined Cave-in-Rock switchgrass established using varying treatments of nitrogen $(\mathrm{N})$ fertilizer and hydromulch application. The treatments chosen were in line with regulation guidelines for revegetation practices in West Virginia. Yields of switchgrass, and soil chemical and physical characteristics, were examined in this study. The objective of this study was to determine appropriate establishment methods for switchgrass on newly reclaimed surface mines.

\subsection{Materials and Methods:}

\subsubsection{Site Locations:}

Two surface mines in southern West Virginia were selected as study sites and planted in June 2011 for this study (Figure 4.1). The sites were chosen because they could be planted the same year reclamation took place which satisfied a key requirement for the objective of this study. The first site is located on the Coal-Mac Phoenix \#5 surface mine (37.7302 N and 82.0761 W) located in Mingo, Logan and Boone Counties and operated by Coal-Mac, a subsidiary of Arch Coal, Inc. This mine is a large mountaintop removal mine that utilizes large earth moving equipment such as draglines, shovels and loaders to remove overburden and coal. The study site location was leveled and prepared by Coal-Mac operators prior to planting. A 60- to 90-cm layer 
of top soil and weathered sandstone mixture was placed on leveled gray sandstone overburden. The study site was laid out, planted, fertilized and mulched from May 31, 2011 through June 2, 2011.

The second site is the Black Castle surface mine $(38.0721 \mathrm{~N}$ and $81.7325 \mathrm{~W})$ operated by Black Castle Mining Company and owned by Alpha Natural Resources. Black Castle is also a large mountaintop removal mine and is located in Boone County, WV. This site was leveled and prepared by Black Castle operators by placing a 20 - to $30-\mathrm{cm}$ layer of topsoil mixed with crushed weathered rock over unweathered overburden. The Black Castle study site was laid out, planted, fertilized and mulched on June 16 and 17, 2011.

Figure 4.1: Location of Coal-Mac and Black Castle mine sites in West Virginia

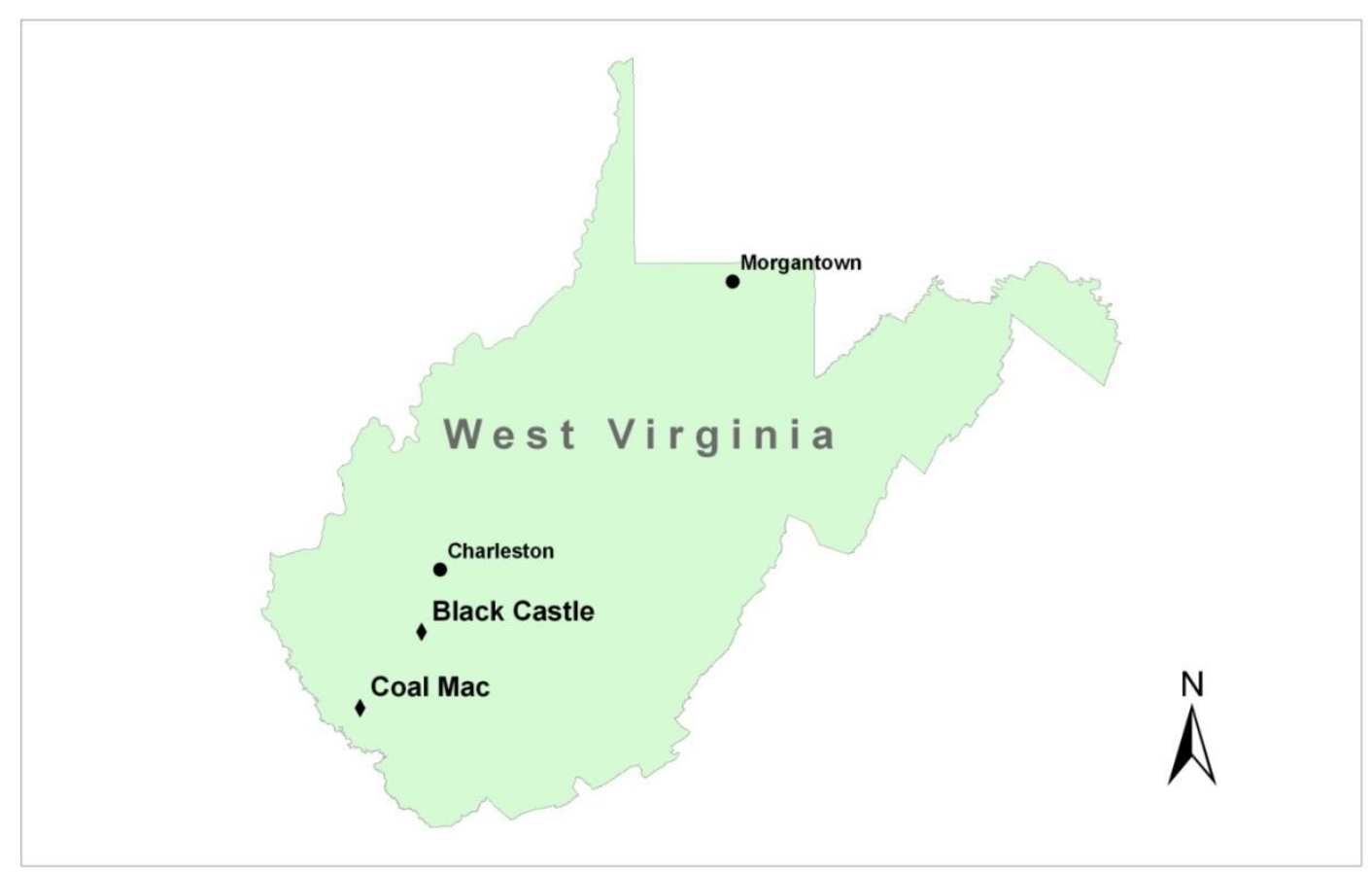




\subsubsection{Experimental Design}

Four treatments were examined to determine establishment methods for growing Cave-inRock switchgrass on freshly reclaimed surface mines in West Virginia. A randomized complete block design with five replications was used as the experimental design. Each block was 0.4 ha with four treatments randomly assigned to one of the quarters in each block. The corners and center of each 0.4-ha plot were marked with steel T-posts. Additionally, the halfway point of each side was marked with flags, which divided each 0.4 -ha plot into four sections or subplots. West Virginia Surface Mining Reclamation Regulations require a minimum of $67 \mathrm{~kg} \mathrm{~N} \mathrm{ha}^{-1}$ and $560 \mathrm{~kg} \mathrm{ha}^{-1}$ of mulch be applied to disturbed areas (WV DEP, 2002). The four treatments used for this experiment are based on two levels of $\mathrm{N}$ fertilizer and two application rates of a wood cellulose hydromulch. The four treatments are: $33.6 \mathrm{~kg} \mathrm{~N} \mathrm{ha}^{-1}$ and a light application of hydromulch; $67 \mathrm{~kg} \mathrm{~N} \mathrm{ha}^{-1}$ and a light application of hydromulch; $33.6 \mathrm{~kg} \mathrm{~N} \mathrm{ha}^{-1}$ and a heavy application of hydromulch; and a control which received no $\mathrm{N}$ fertilizer and a light application of hydromulch. Light mulch treatments received approximately $1.7 \mathrm{Mg} \mathrm{ha}^{-1}$ and heavy mulch treatments received approximately $3.0 \mathrm{Mg} \mathrm{ha}^{-1}$ on a dry material basis.

Using a Solo 421-S Portable Spreader, seed was applied at a rate of $11.2 \mathrm{~kg} \mathrm{PLS} \mathrm{ha}^{-1}$ to each plot. Seed was purchased from Ernst Conservation Seed (Meadville, PA). Fertilizer, in the form of 10-10-10, was weighed and spread evenly by hand. The hydromulch was applied by mine operators after each plot had been fertilized and seeded. Once an entire 0.4-ha plot received an even coat of hydromulch, additional mulch was spread on the subplot assigned to receive the heavy hydromulch treatment.

Vegetation measurements and soil samples were taken once during the growing season from three randomly selected sampling points within each quarter of the 0.4-ha plots. Random 
sampling points were selected using Hawth's Tools in ArcMap 10 (ESRI, 2011). Figures 4.2 and 4.3 display the treatment layouts within each block at both sites as well as the location of random sampling points. Sampling point coordinates can be found in Appendix 1.

Figure 4.2: Site layout of Coal-Mac showing plots, treatments and sampling points.

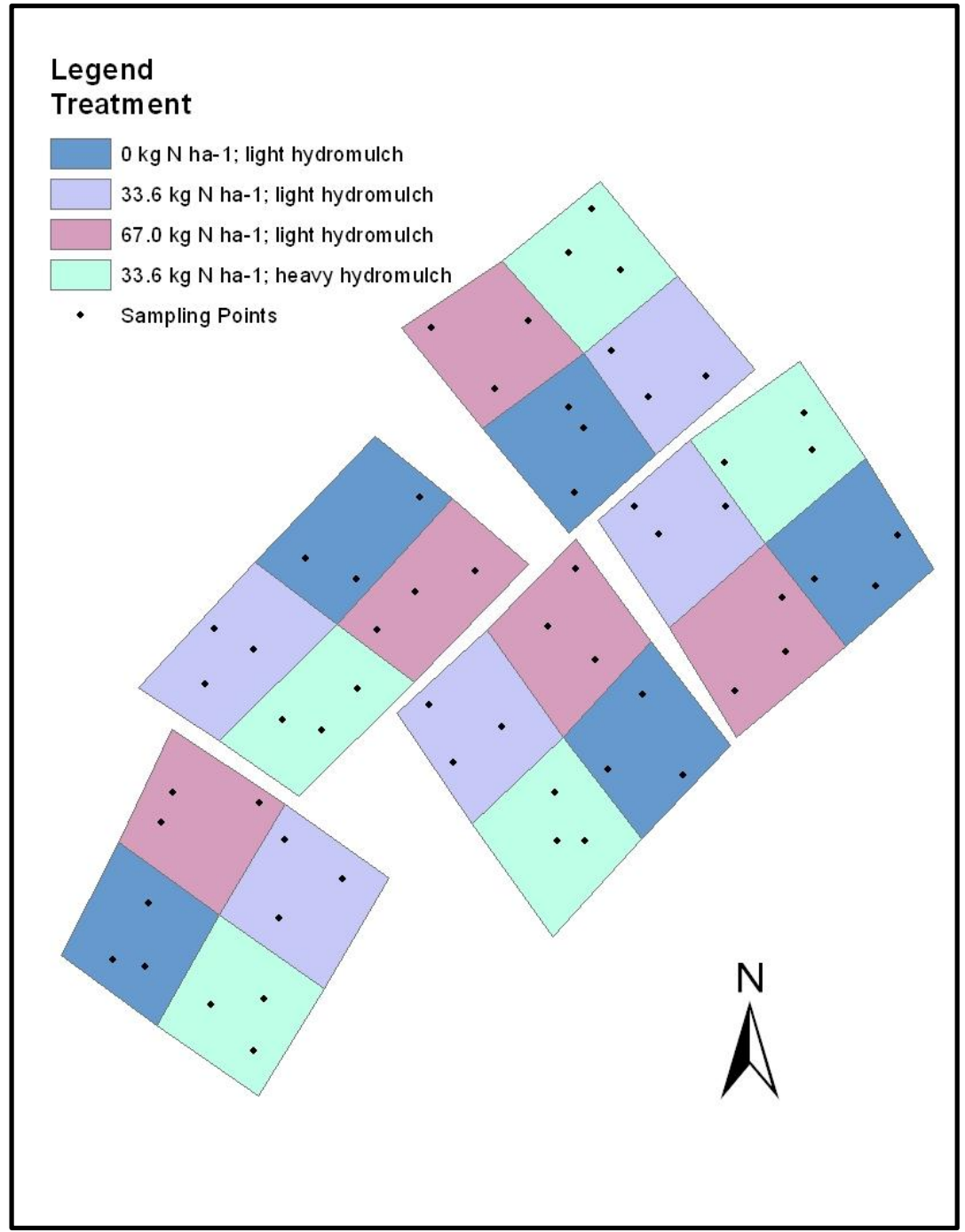


Figure 4.3: Site layout of Black Castle showing plots, treatments and sampling points.

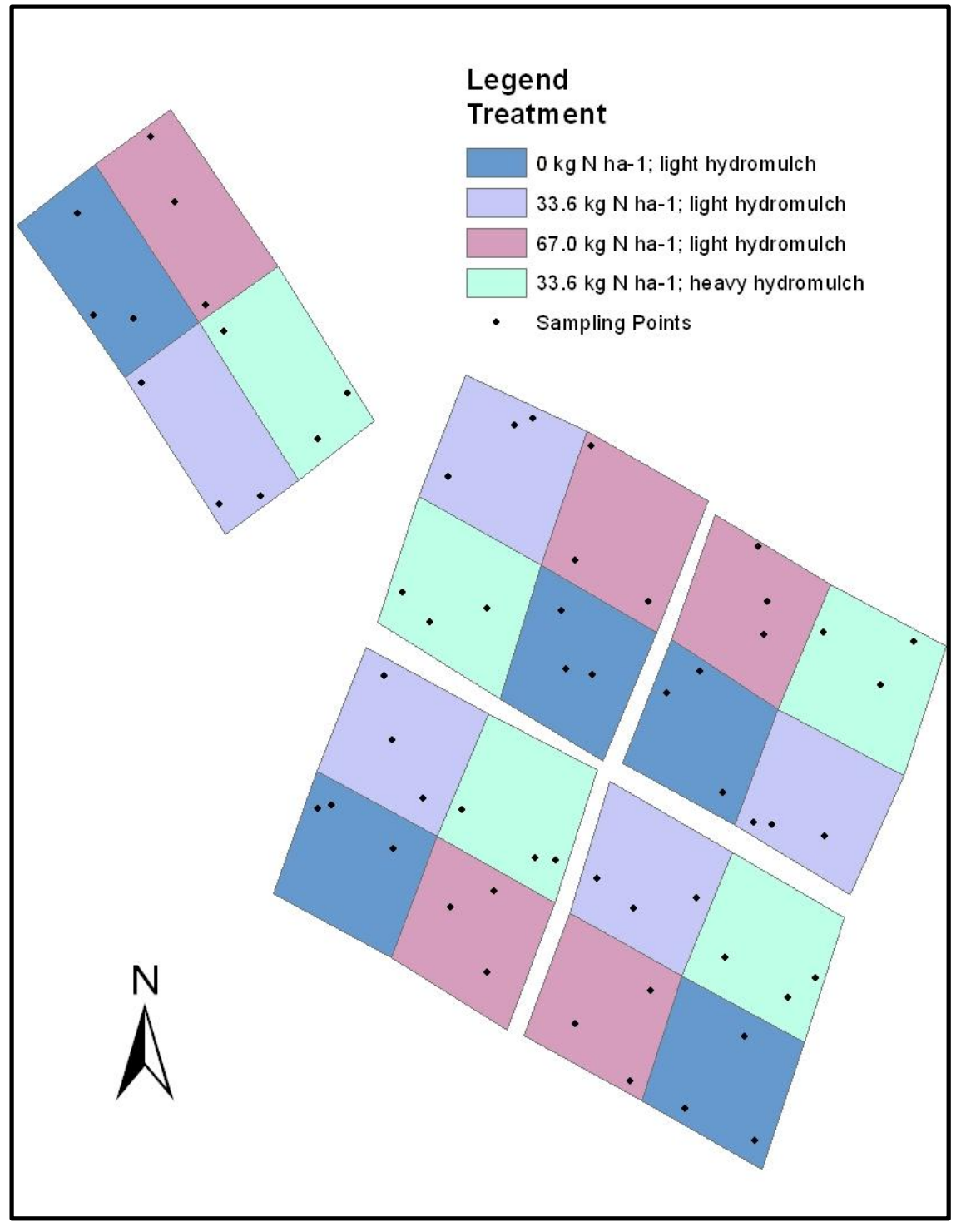

\subsubsection{Vegetation Measurement and Analysis}

Yield is typically not collected after the first growing season for switchgrass because of its slow establishment and minimal production the first year. However due to significant switchgrass growth within treatments, it was determined yield collection and analysis would be conducted at the end of the first growing season. Yield was collected at both sites on October 
26, 2011. Biomass was determined by placing a $0.21-\mathrm{m}^{2}$ quadrat within $1 \mathrm{~m}$ of each random sampling location and clipping all switchgrass within the quadrat to approximately $5-8 \mathrm{~cm}$ with the goal to collect the maximum amount of biomass without clipping at ground level. This clipping height was used for other studies conducted in this area and was maintained for consistency. Stand persistence is not a concern since samples will be taken from a small proportion of the entire plot. During clipping, non-switchgrass material was discarded from the sample. Yield was expressed as the weight of the clipped samples oven dried at $60^{\circ} \mathrm{C}$ to a constant weight to determine dry weight.

Frequency and percent cover of switchgrass were also measured in 2011 and the results led to the decision to collect biomass after just one growing season. The percent ground covered by switchgrass was estimated using a modified Daubenmire method (Daubenmire, 1956) and a specific class was assigned by placing a $1.0-\mathrm{m}^{2}$ quadrat at each randomly selected sampling point. Seven coverage classes were used $(0-1 \%, 1-5 \%, 5-25 \% .25-50 \%, 50-75 \%, 75-95 \%$ and 95-100\%). The mid-point of each coverage class was used for statistical analysis. Frequency was estimated by placing a $1.0-\mathrm{m}^{2}$ quadrat at each cardinal direction of each random sample point. Frequency was measured as the number of times a switchgrass plant was present in the quadrat. Presence was considered if the plant was rooted within the quadrat. Frequency was calculated by determining the proportion of quadrats within a treatment that had at least one switchgrass plant. In this case, sixty quadrats were tested per treatment per site. 
Figure 4.4.: Percent cover measured using modified Daubenmire Method.

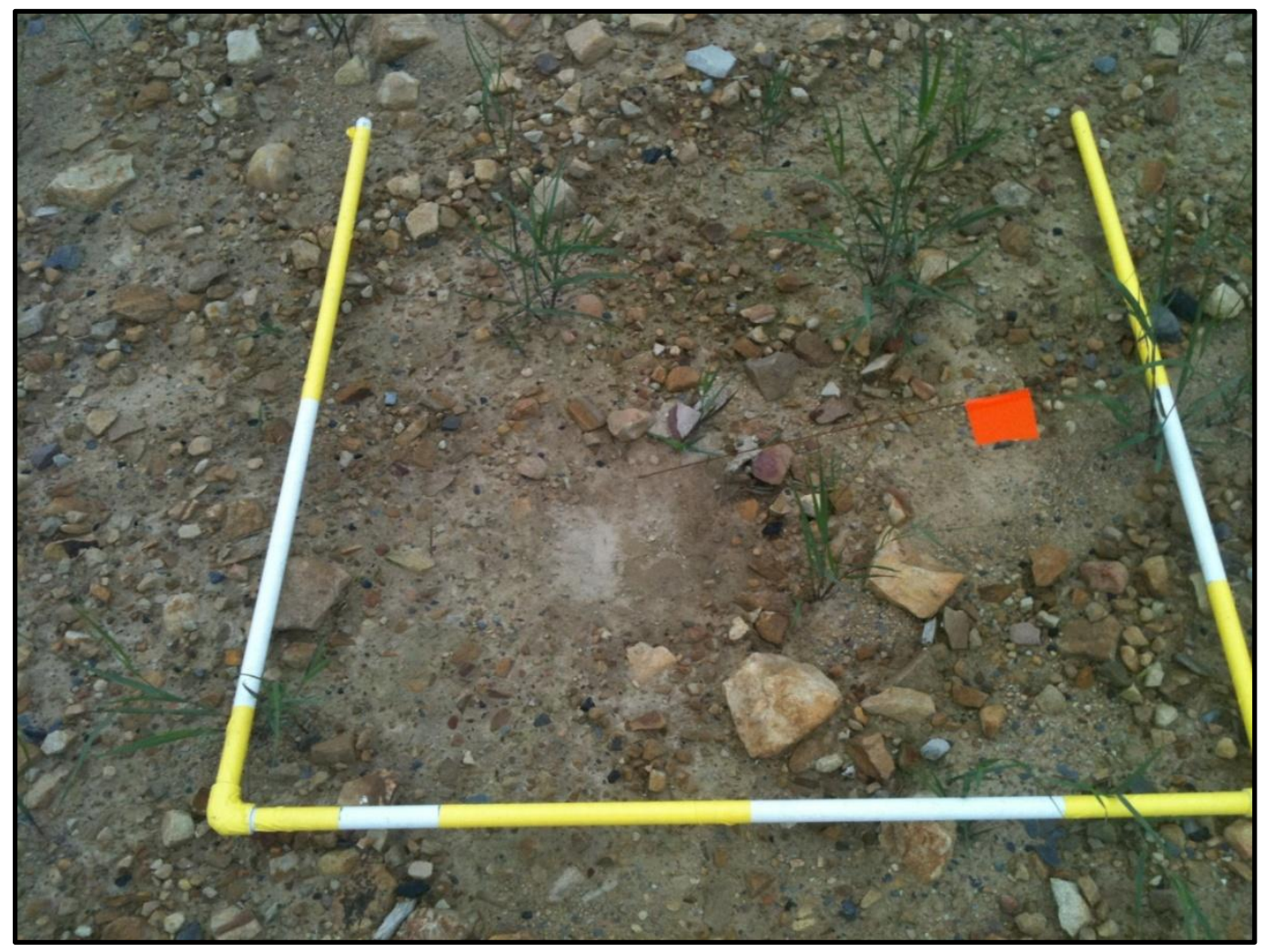

Frequency and cover of plants were analyzed as a precursor to yield. Frequency was determined by observing the number of times a switchgrass plant was sampled within a given amount of sample quadrats of a given size. Frequency was calculated as a percent and standard deviation by site and treatment. Analysis of cover, a proportion, was done using a generalized linear model in which the data were modeled by a binomial distribution. Statistical analysis of cover was conducted in SAS (2008) using the logit link function. A two-way analysis of variance (ANOVA) in R (R Core Team, 2012) was used to assess the main effects of site and treatment on the response variable, yield, as well as to determine if an interaction took place between the main effects. Factor-level mean comparisons were conducted using Tukey's Honestly Significant Difference (HSD) Test, also conducted in R. Statistical significance was based on a p-value of 
0.05. Yield analysis was completed using square root transformed data. The method of data transformation was based on the Box-Cox method (Faraway, 2004).

\subsubsection{Soil Sampling}

Soil samples were collected at both sites in August 2011 and were used to analyze soil chemical and physical properties. Soil samples were collected by taking a shovel slice from each of the three random sample locations within each subplot to a depth of approximately $15 \mathrm{~cm}$.

Once collected, all samples were air dried, weighed, and sieved with a US \#10 2-mm sieve. During the sieving process, effort was made to break most soil clods by hand or using a hammer in order to ensure the material in the clods was accounted for in the fine fraction. The fine fraction (sample fraction $<2 \mathrm{~mm}$ ) was collected and used for chemical analysis. The rock fraction (>2 mm) was collected, washed through a US \#10 $2 \mathrm{~mm}$ sieve, air dried and reweighed to determine the portion of the sample made up of rock-sized fragments. The washing process breaks apart any remaining soil clods and removes excess fine materials attached to rocks. Percent rock fragments were calculated for each sample by dividing the weight of the rocks by the total weight of the sample and multiplying by $100 \%$.

\subsubsection{Soil Chemical Measurement and Analysis}

All soil chemical analyses were completed using the fine portion of each soil sample and analyzed for $\mathrm{pH}, \mathrm{EC}$, and available nutrients. To determine $\mathrm{pH}, 5 \mathrm{~g}$ of soil were combined with $5 \mathrm{~mL}$ of distilled de-ionized (DDI) water. The mixture was placed on a reciprocating shaker table and mixed for 15 minutes, then allowed to equilibrate for at least 1 hour. A Mettler Toledo SevenEasy $\mathrm{pH}$ Meter was used to take the $\mathrm{pH}$ readings. EC was determined by combining $5 \mathrm{~g}$ of soil with $10 \mathrm{~mL}$ DDI water. The mixture was placed on a reciprocating shaker table and mixed 
for 15 minutes, then allowed to equilibrate for at least 1 hour. A Fisher Scientific Accumet Excel (XL60) Dual Channel pH/Ion/Conductivity/DO Meter was used to take EC readings.

Mehlich 1 solution, also referred to as Dilute Double Acid solution, composed of 0.0025 $N \mathrm{H} 2 \mathrm{~S} 04+0.05 \mathrm{~N} \mathrm{HCl}$ was used to extract available elements from the soil (Wolf and Beegle, 1995). For the extraction, $25 \mathrm{~mL}$ of the Mehlich 1 solution was added to $5 \mathrm{~g}$ of soil, mixed on a reciprocating shaker for 5 minutes, then allowed to equilibrate. The samples were then filtered through Fisher Scientific Q5 Filter Paper. Using an inductively coupled plasma emission spectrometer (Optima 2100 DV, Perkin Elmer Corporation, Norwalk, CT) the following element concentrations were determined: $\mathrm{Al}, \mathrm{Fe}, \mathrm{Mn}, \mathrm{Mg}, \mathrm{Ca}, \mathrm{K}, \mathrm{P}, \mathrm{Ni}, \mathrm{Cu}$, and $\mathrm{Zn}$.

\subsubsection{Soil Particle Size Analysis}

Soil particle size was determined using the pipette method (Gee and Bauder, 1986). Ten samples were randomly selected from each site for this analysis. Approximately $40 \mathrm{~g}$ of soil was measured into $300 \mathrm{~mL}$ fleaker and then $10 \mathrm{ml}$ of hydrogen peroxide (30 wt. \%) was added to remove organic matter. Addition of hydrogen peroxide caused samples to bubble and froth vigorously. Once bubbling calmed, fleakers were placed on hot plate set at approximately 60$70^{\circ} \mathrm{C}$. Additional hydrogen peroxide was added $5 \mathrm{ml}$ at a time while the fleaker remained on the hot plate and the reaction was allowed to proceed until most of organic matter was burned, indicated by lack of bubbling.

Once organic matter was burned off, samples were then oven dried at $105^{\circ} \mathrm{C}$ for 24 to 48 hrs. Once completely dried, samples were removed, allowed to cool and weighed to record starting soil weight. A solution of $10 \mathrm{~mL}$ of sodium hexametaphosphate (HMP) at a concentration of $50 \mathrm{~g} \mathrm{~L}^{-1}$ was added to each fleaker as a dispersion agent. Using approximately 100 to $150 \mathrm{~mL}$ DDI water, all of the contents in the fleaker were carefully transferred to a 
stainless steel milkshake container and mixed for approximately $5 \mathrm{~min}$. Samples were then washed from the stainless container into $1 \mathrm{~L}$ volumetric settling columns and filled to capacity with DDI water. Samples were mixed end-over-end for $1 \mathrm{~min}$ and then allowed to settle for a specific amount of time. Settling time, which is based on the constant settling rate of soil particles based on size and temperature as predicted by Stoke's Law, was based on the temperature of a column filled with DDI water

After settling, the top $25 \mathrm{~mL}$ of liquid from each settling column were pipetted into a preweighed beaker to measure amount of suspended clay particles. The remaining contents in the settling column were emptied through a US \#270 $(.053 \mathrm{~mm})$ sieve to collect sand-sized particles. The sand in the sieve was washed with tap water to remove all silt. Washing continued until water running through the sieve was completely clear. Once washed, the sand was transferred to a pre-weighed beaker. Beakers containing clay and sand were oven dried at $105^{\circ} \mathrm{C}$ for 24 to 48 hrs. Dried beakers were reweighed to determine the percent sand and clay of the total soil sample. Percent silt sized particles were determined as the difference between the sand and clay from the total soil sample.

Soil chemical and physical data were analyzed using principal components analysis (PCA) in R (R Core Team, 2012). Soil chemical and physical data included the following: proportion of fine-sized particles ( $<2 \mathrm{~mm}$ ) (fines), $\mathrm{pH}, \mathrm{EC}, \mathrm{Al}, \mathrm{Fe}, \mathrm{Mn}, \mathrm{Mg}, \mathrm{Ca}, \mathrm{K}, \mathrm{P}, \mathrm{Ni}, \mathrm{Cu}$, and $\mathrm{Zn}$. The purpose of using PCA was to represent the thirteen chemical variables and percent fines in a composite set of variables to explain some of the variation among the two sites. Prior to analysis, the data were standardized and checked for correlated variables. Strong correlations between variables were obtained and thus some variables were omitted from the analysis to reduce multicollinearity. 
Examination of a correlation matrix revealed $\mathrm{Al}, \mathrm{Cu}, \mathrm{Zn}$ and $\mathrm{Ni}$ were highly correlated; therefore $\mathrm{Cu}, \mathrm{Zn}$ and $\mathrm{Ni}$ were excluded from the analysis. Additionally, $\mathrm{Mg}$ was highly correlated with $\mathrm{Mn}$ and $\mathrm{Ca}$, thus $\mathrm{Mn}$ and $\mathrm{Ca}$ were excluded from further analysis. PCA in R was conducted on the new data set, which included the remaining chemical variables which included $\mathrm{pH}$, \% fines, EC, Al, Fe, Mg, K, Na, and P. Principal components with eigenvalues greater than 1.0 were kept for further analysis and all others were discarded.

\subsection{Results and Discussion}

\subsubsection{Vegetation Measurement}

Analysis of percent cover was conducted by site and treatment at both Coal-Mac and Black Castle sites. Type 3 analysis of effects of the LOGISTIC procedure determined that both site and treatment were significant and that site*treatment interactions were not significant for percent cover (Table 4.1). Black Castle had better overall percent cover compared to Coal-Mac at $8.8 \%$ compared to $2.3 \%(\mathrm{Pr}>\mathrm{ChiSq}=0.0004)$. Examining percent cover by treatment across sites revealed that all plots receiving any amount of $\mathrm{N}$ had significantly better cover after one growing season compared to plots with no $\mathrm{N}$. Plots receiving no $\mathrm{N}$ had an overall mean cover of only $1.1 \%$. Plots receiving $33.6 \mathrm{~kg} \mathrm{~N} \mathrm{Na}^{-1}$ with light hydromulch had a mean percent cover of $4.5 \%$ and plots receiving the same $\mathrm{N}$ level but with heavy hydromulch were comparable with a mean cover of $5.2 \%$. No statistical difference was determined between plots receiving $33.6 \mathrm{~kg} \mathrm{~N}$ $\mathrm{ha}^{-1}$ and light and heavy hydromulch. Plots receiving $67.0 \mathrm{~kg} \mathrm{~N}^{-1}$ had a significantly greater

mean cover of $11.3 \%$. Mean contrasts between plots receiving $67.0 \mathrm{~kg} \mathrm{~N}^{-1}$ and plots receiving $33.6 \mathrm{~kg} \mathrm{~N} \mathrm{ha}^{-1}$ revealed a statistical difference at a p-value $<0.1000(\mathrm{Pr}>\mathrm{ChiSq}=0.0880)$. Data 
for frequency reinforced the results of cover. In general, all plots with any amount of $\mathrm{N}$ amendment had better percent cover compared to plots with $0 \mathrm{~kg} \mathrm{~N} \mathrm{ha}^{-1}$ (Table 4.2).

Table 4.1: Type 3 analysis of effects for percent cover.

\section{Degrees of Freedom $\quad$ Wald Chi-Square $\quad$ Pr $>$ ChiSq}

Site

$+1$

$1 \quad 12.5975$

$0.0004 \uparrow$

Treatment

3

17.3554

$0.0006+$

Site ${ }^{* T}$ Treatment

3

6.0676

0.1084

$\dagger$ Indicates a significance at $\mathrm{p}$-value $<0.05$

Table 4.2: Percent frequency of switchgrass by site and treatment.

\begin{tabular}{lccc}
\hline Treatment & Black Castle & Coal Mac & \multicolumn{1}{c}{ Cover Across Sites } \\
\hline \multirow{2}{*}{ No fertilizer; light mulch } & $63.3( \pm 7.5)$ & $61.7( \pm 28.0)$ & ------\% Cover----- \\
$33.6 \mathrm{~kg} \mathrm{~N} \mathrm{ha}^{-1}$; light mulch & $81.7( \pm 16.0)$ & $90.0( \pm 18.1)$ & $4.5 \%$ \\
$33.6 \mathrm{~kg} \mathrm{~N} \mathrm{ha}^{-1}$; heavy mulch & $78.3( \pm 31.0)$ & $96.7( \pm 7.5)$ & $5.2 \%$ \\
$67 \mathrm{~kg} \mathrm{~N} \mathrm{ha}^{-1} ;$ light mulch & $81.7( \pm 23.9)$ & $93.3( \pm 7.0)$ & $11.3 \%$ \\
\hline
\end{tabular}

Results of percent cover and frequency led to a decision to determine yield after just one growing season, although harvest of switchgrass grown for biofuel production is not common in the first year. A two-way ANOVA was used to examine yield response to main effects, site and treatment. Both main effects were significant at $\mathrm{p}$-value $<0.05$. There was no significant effect associated with the interaction site*treatment (Tables 4.3 and 4.4). Both sites responded 
positively to fertilizer application, however the switchgrass growing at Black Castle seemed to respond at a greater magnitude to fertilizer compared to Coal-Mac (Figure 4.5)

Table 4.3: Two-way ANOVA table with yield as response variables.

\begin{tabular}{lccc}
\hline & Degrees of Freedom & F value & $\operatorname{Pr}(>\mathbf{F})$ \\
\cline { 2 - 4 } Site & 1 & 7.8098 & $0.0087 \dagger$ \\
Treatment & 3 & 10.8373 & $0.00004 \dagger$ \\
Site*Treatment & 3 & 1.7601 & 0.1746 \\
\hline
\end{tabular}

$\dagger$ Indicates a significance at $\mathrm{p}$-value $<0.05$

Table 4.4: Two-way ANOVA Results and mean yields for Switchgrass grown using four establishment treatment methods.

\begin{tabular}{|c|c|c|c|c|c|c|}
\hline Effect & & $\mathbf{P}>\mathbf{F}^{*}$ & Mean & Mean & SD $\uparrow$ & CV: \\
\hline & & & $\mathrm{Kg} \mathrm{ha}^{-1}$ & --Square & Root Y & Data* \\
\hline \multirow[t]{3}{*}{ Site } & & 0.0087 & & & & \\
\hline & Coal-Mac & & $248^{B}$ & $13.6^{\mathrm{B}}$ & 8.1 & \\
\hline & Black Castle & & $543^{A}$ & $19.3^{\mathrm{A}}$ & 13.3 & \\
\hline \multirow[t]{5}{*}{ Treatment } & & 0.00004 & & & & \\
\hline & No Fertilizer; light mulch & & $67^{\mathrm{B}}$ & $3.9^{\mathrm{B}}$ & 7.6 & \\
\hline & $33.6 \mathrm{~kg} \mathrm{~N} \mathrm{ha}^{-1}$; light mulch & & $362^{A}$ & $17.4^{\mathrm{A}}$ & 8.0 & \\
\hline & $33.6 \mathrm{~kg} \mathrm{~N} \mathrm{ha}^{-1}$; heavy mulch & & $375^{\mathrm{A}}$ & $18.8^{\mathrm{A}}$ & 5.1 & \\
\hline & $67 \mathrm{~kg} \mathrm{~N} \mathrm{ha}^{-1}$, light mulch & & $777^{\mathrm{A}}$ & $25.8^{\mathrm{A}}$ & 11.1 & \\
\hline
\end{tabular}

Site*Treatment

Coal-Mac

No Fertilizer; light mulch

$33.6 \mathrm{~kg} \mathrm{~N} \mathrm{ha}^{-1}$; light mulch

$33.6 \mathrm{~kg} \mathrm{~N} \mathrm{ha}^{-1}$; heavy mulch

NS

$67 \mathrm{~kg} \mathrm{~N} \mathrm{ha}^{-1}$, light mulch

Black Castle

No Fertilizer; light mulch

$33.6 \mathrm{~kg} \mathrm{~N} \mathrm{ha}^{-1}$; light mulch

$33.6 \mathrm{~kg} \mathrm{~N} \mathrm{ha}^{-1}$; heavy mulch

$67 \mathrm{~kg} \mathrm{~N} \mathrm{ha}^{-1}$, light mulch

$\begin{array}{cccc}116 & 5.9 & 10.1 & 1.70 \\ 278 & 15.2 & 7.8 & 0.51 \\ 256 & 15.6 & 4.0 & 0.25 \\ 341 & 17.8 & 5.5 & 0.31 \\ & & & \\ 17 & 1.9 & 4.2 & 2.24 \\ 447 & 19.7 & 8.5 & 0.43 \\ 495 & 21.9 & 4.2 & 0.19 \\ 1212 & 33.8 & 9.2 & 0.27\end{array}$


*Statistics and p-values determined using square root transformed data.

$\uparrow$ Standard Deviation

\pm Coefficient of Variation

Figure 4.5: Interaction plot of square root transformed yield data by site and treatment.

Interaction plot of square root transformed yield by site and treatment

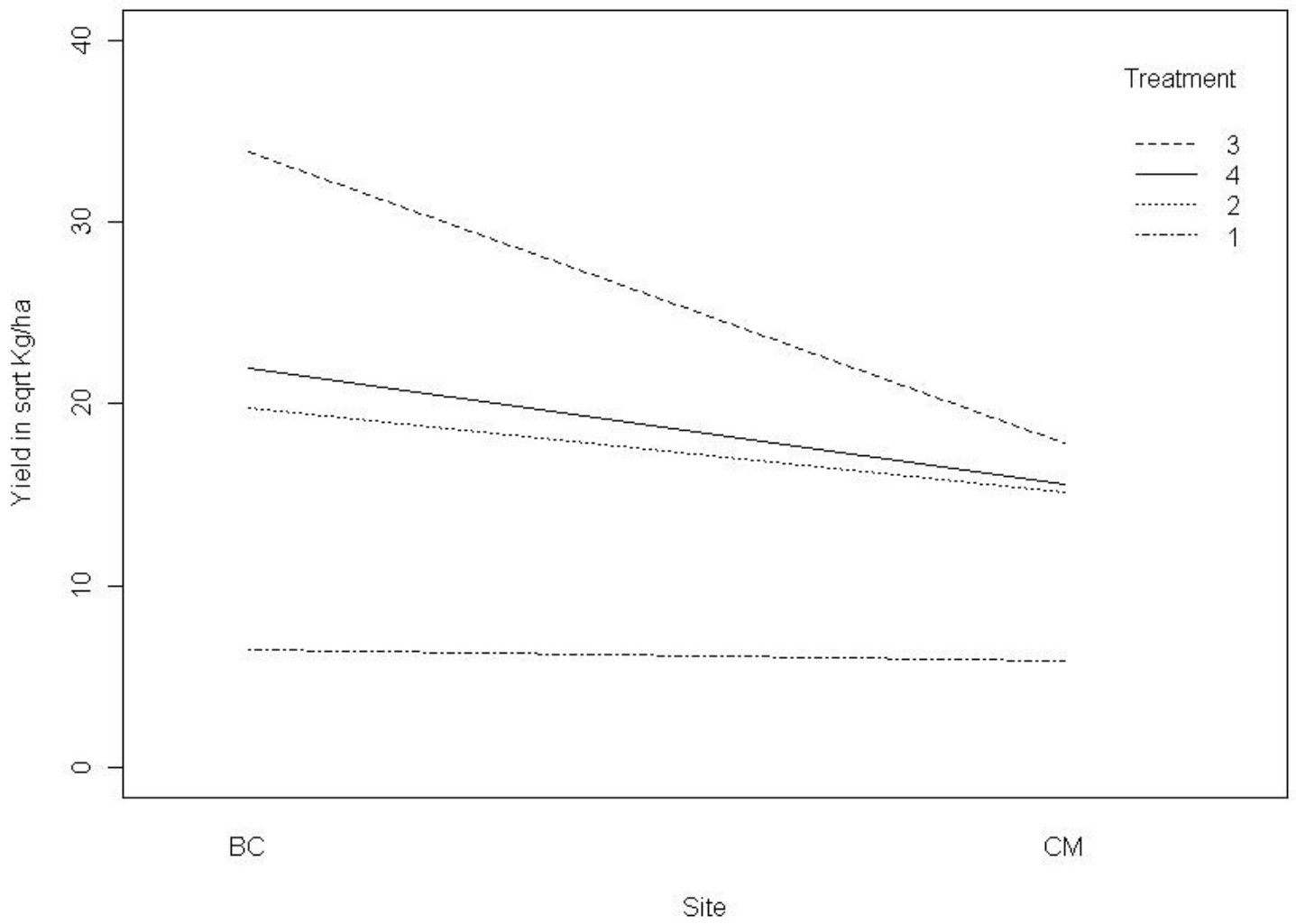

Treatment Key:

1. $0 \mathrm{~kg} \mathrm{~N} \mathrm{ha}{ }^{-1}$; light hydromulch

2. $33.6 \mathrm{~kg} \mathrm{~N} \mathrm{ha}^{-1}$; light hydromulch

3. $67.0 \mathrm{~kg} \mathrm{~N} \mathrm{ha}^{-1}$; light hydromulch

4. $33.6 \mathrm{~kg} \mathrm{~N} \mathrm{ha}^{-1}$; heavy hydromulch

There was a significant difference between the first season yield at Black Castle and CoalMac mine sites, which shows that switchgrass grew better at the Black Castle mine site. Averaged across treatment, Black Castle experienced higher yields (543 $\mathrm{kg} \mathrm{ha}^{-1}$ ) compared to Coal-Mac $\left(248 \mathrm{~kg} \mathrm{ha}^{-1}\right)$. Looking more closely at an interaction plot of square root transformed 
yield by site and treatment, it appears that both sites grew similarly on plots treated with $0 \mathrm{~kg} \mathrm{~N}$ $\mathrm{ha}^{-1}$. However, Black Castle seemed to have more of a response to treatments of $\mathrm{N}$ and hydromulch compared to Coal-Mac (Figure 4.5). Both sites appear to have responded similarly to treatments, which is confirmed by no significant difference in a site*treatment interaction reported by the ANOVA results.

Significance associated with the main effect, treatment, which consisted of varying levels of $\mathrm{N}$ fertilizer and hydromulch application, confirmed yields changed with $\mathrm{N}$ fertilizer amendments. It appeared as though switchgrass yields increased with $\mathrm{N}$ application rates. Mean level comparisons were used for further examination.

Tukey's HSD test was used to compare square root transformed factor level means of the four treatments. Averaged across sites, untransformed yield data for the 0 fertilizer (plus light mulch), $33.6 \mathrm{~kg} \mathrm{~N} \mathrm{ha}^{-1}$ (plus light mulch), $67 \mathrm{~kg} \mathrm{~N} \mathrm{ha}^{-1}$ (plus light mulch) and $33.6 \mathrm{~kg} \mathrm{~N} \mathrm{ha}^{-1}$ (plus heavy mulch) were $67 \mathrm{~kg} \mathrm{ha}^{-1}, 362 \mathrm{~kg} \mathrm{ha}^{-1}, 777 \mathrm{~kg} \mathrm{ha}^{-1}$ and $375 \mathrm{~kg} \mathrm{ha}^{-1}$, respectively. The treatment receiving no fertilizer and a light application of hydromulch was significantly different than the three other treatments which received some level of $\mathrm{N}$ application. No significant difference was found between means of the three treatments which received $\mathrm{N}$ (Tables 4.4 and 4.5). 
Table 4.5: Untransformed treatment yields at Black Castle and Coal-Mac.

\begin{tabular}{|c|c|c|c|}
\hline \multirow[t]{2}{*}{ Treatment } & \multicolumn{3}{|c|}{ Yield } \\
\hline & Black Castle & Coal Mac & Average Across Site \\
\hline & ------------------ & $-\mathrm{kg} \mathrm{ha}^{-1}-$ & ------------------------ \\
\hline No fertilizer; light mulch & 17 & 116 & $67^{\mathrm{B}^{*}}$ \\
\hline $33.6 \mathrm{~kg} \mathrm{~N} \mathrm{ha}^{-1}$; light mulch & 447 & 278 & $363^{\mathrm{A}}$ \\
\hline $33.6 \mathrm{~kg} \mathrm{~N} \mathrm{ha}^{-1}$; heavy mulch & 495 & 255 & $375^{\mathrm{A}}$ \\
\hline $67 \mathrm{~kg} \mathrm{~N} \mathrm{ha}^{-1}$; light mulch & 1212 & 341 & $777^{\mathrm{A}}$ \\
\hline
\end{tabular}

*Letters denote statistical difference at $(\mathrm{p}<0.05)$ between varieties within harvest management system. Test for significance was performed on square root transformed data in order to satisfy normality assumptions associated with statistical methods.

It was interesting that there was no statistical difference between the plots treated with different levels of N. Averaged across site there was no statistical difference between plots fertilized with $33.6 \mathrm{~kg} \mathrm{~N} \mathrm{ha}^{-1}$ and $67 \mathrm{~kg} \mathrm{~N} \mathrm{ha}^{-1}$. In a study using similar treatments, Haque et al. 2009 found that an $\mathrm{N}$ treatment of $67 \mathrm{~kg} \mathrm{~N} \mathrm{ha}^{-1} \mathrm{yr}^{-1}$ produced more switchgrass biomass compared to $34 \mathrm{~kg} \mathrm{~N} \mathrm{ha}^{-1} \mathrm{yr}^{-1}$ for single harvest systems. The Haque et al.(2009) study differs slightly from this study in that they reported yields averaged across a three-year study but they did not harvest biomass during the establishment year. Tukey's HSD test was performed post hoc on all treatment yields within both sites even though site*treatment was not significant (p $=0.17$ ). This information was not included in Tables 4.4 and 4.5. When looking at treatment contrasts within Coal-Mac, there was no significant difference among any of the treatments. Conversely, at Black Castle, plots fertilized with $67 \mathrm{~kg} \mathrm{~N} \mathrm{ha}^{-1}$ were significantly different than plots fertilized with $33.6 \mathrm{~kg} \mathrm{~N} \mathrm{ha}^{-1}$ and $0 \mathrm{~kg} \mathrm{~N}$. There was no significant difference among the other treatments at Black Castle.

The effect of different mulch applications on yield was not clear. Any addition of hydromulch would aid seed to soil contact and likely protect seeds from blowing or washing 
away. It may also have provided a good initial source of water for seed to germinate. It is not clear from this study that hydromulch played any role in the yield differences between the plots. Based on treatment level comparisons (Table 4.4), the extra hydromulch applied to plots treated with $33.6 \mathrm{~kg} \mathrm{~N} \mathrm{ha}^{-1}$ did not affect yield. It is unlikely that the hydromulch added any nutritive value to the mine soils used in this study this early after application. In a study examining the use of hydroseed and compost to reclaim road-side soils, no significant difference was found in plots reclaimed with hydroseed (Dunifon et al., 2011).

\subsubsection{Soil Chemical and Physical Properties}

PCA was conducted on a reduced data matrix which included yield in response to the nine environmental variables retained after the test for correlations: $\mathrm{pH}, \%$ fines, $\mathrm{EC}, \mathrm{Al}, \mathrm{Fe}, \mathrm{Mg}$, $\mathrm{K}, \mathrm{Na}$, and $\mathrm{P}$. The first three principal components scored eigenvalues greater than 1.0 and thus were retained in the PCA for soil chemical and physical data. The first three PC's accounted for $82 \%$ of the variability within the original data set. PC1, PC2 and PC3 had eigenvalues of 4.07, 1.92 and 1.38 , respectively. Factor loadings, or eigenvectors, within each PC were examined to determine how the original variables related to each PC. For this study, factor loadings with an absolute value greater than or equal to 0.80 were considered for further examination. The micronutrients $\mathrm{Al}, \mathrm{Fe}$, macronutrient $\mathrm{Mg}$, and EC loaded highly in PC1. Potassium loaded highly in PC2. Additionally, P loaded at 0.77 in PC2 and was included in further analysis because of its proximity to 0.80 and its importance to plant growth. PC3 was related to percent fine material in the soil (Table 4.5). 
Table 4.6: Eigenvectors by Principal Components.

\begin{tabular}{ccc}
\hline PC1 & PC2 & PC3 \\
\hline EC $(-0.902)$ & $\mathrm{K}(-0.891)$ & \% Fines $(0.823)$ \\
$\mathrm{Al}(-0.928)$ & $\mathrm{P}(-0.765)$ & \\
$\mathrm{Fe}(-0.807)$ & & \\
$\mathrm{Mg}(-0.929)$ & & \\
\hline
\end{tabular}

Examining each plot, named by specific site, on a graph using PC1 and PC2 as axes shows a strong separation by site (Figure 4.6). This separation indicates that there is a chemical and physical difference between the Black Castle and Coal-Mac mine sites. To determine which variables contribute to the differences, a biplot of the factor loadings was created and placed over the plots displayed along axes using PC1 and PC2. Factor loadings are displayed as arrows and the direction and length of the arrow represents the PC on which the factor loads and the strength with which it loads, respectively. Arrows running horizontally indicate loading on PC1 and arrows running vertically indicate loading on PC2. In this case, all variables with factor loadings greater than 0.80 and P load strongly in the direction of Black Castle plots (Figure 4.6). 
Figure 4.6: Biplot displaying sites and factor loadings of soil chemical and physical variables along Principal Components 1 and 2.

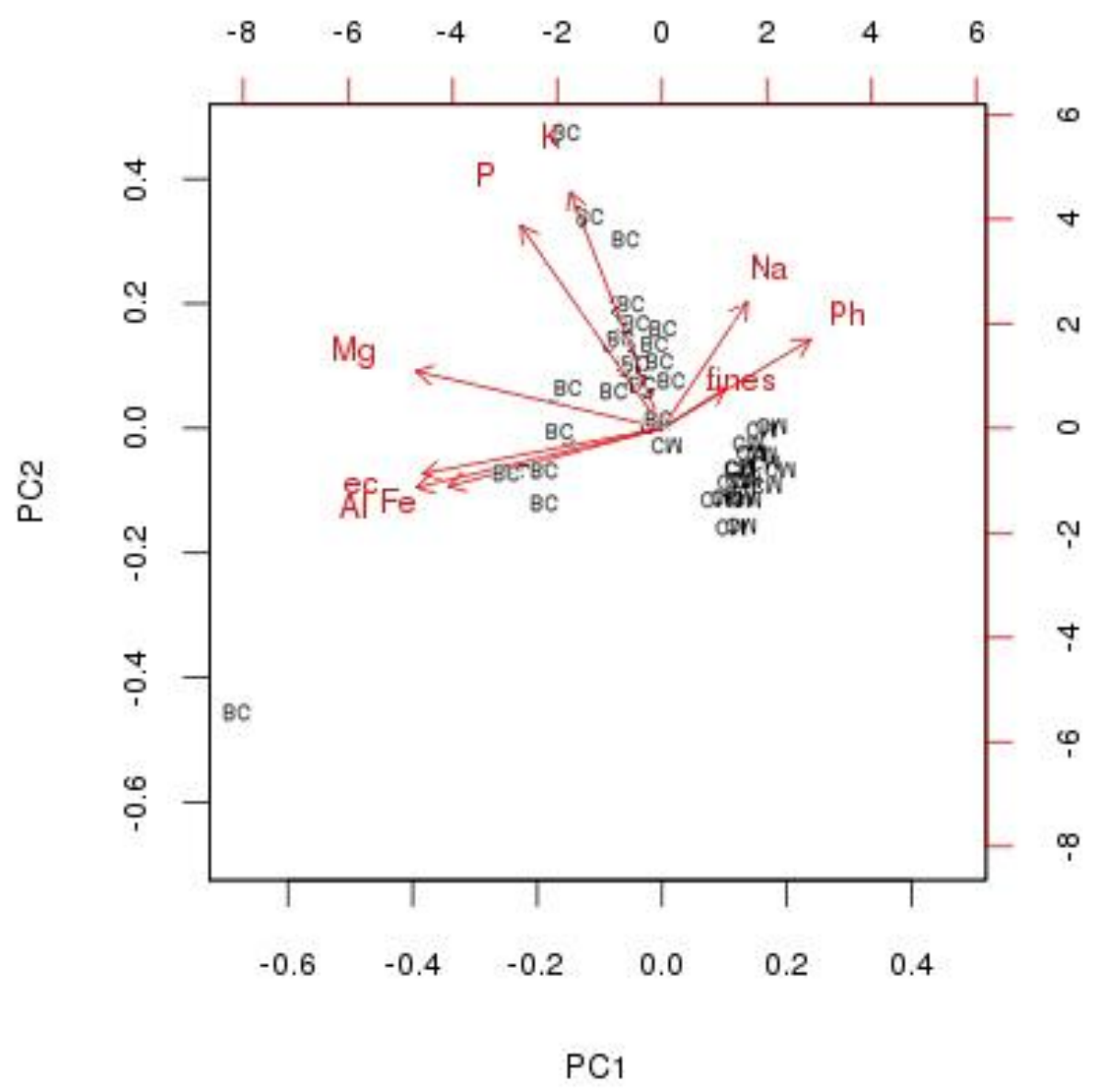

Examination of the site means for each variable shows a clear difference between the two sites used for this study (Table 4.7). Variables from Black Castle associated with PC1 and PC2, all had higher site means compared to Coal-Mac. This included higher levels of the macronutrients $\mathrm{P}, \mathrm{K}, \mathrm{Mg}$ and micronutrients $\mathrm{Al}$ and Fe. PC3 seemed to differentiate the site by percent of fine-sized particles. Percent fine-sized material at Black Castle and Coal-Mac were comparable and the eigenvalue for PC3 was relatively low, which corresponds to the shortness of 
the arrow. This infers that this variable may not have influenced the difference in yield between the two sites.

Table 4.7 : Site means of highly loading eigenvectors.

\begin{tabular}{lcccc}
\hline & \multicolumn{2}{c}{ Coal-Mac } & \multicolumn{2}{c}{ Black Castle } \\
\cline { 2 - 5 } & Mean & COV $\neq$ & Mean & COVł \\
\hline proportion fines $\dagger$ & 0.558 & 0.2134 & 0.5344 & 0.152879 \\
Ph & 5.99 & 0.14 & 5.67 & 0.16 \\
EC & 165.73 & 0.57 & 842.81 & 1.04 \\
Al* $^{*}$ & 5.72 & 2.62 & 56.49 & 1.11 \\
Fe $^{*}$ & 1.95 & 1.37 & 34.24 & 2.02 \\
$\mathbf{M n}^{*}$ & 1.91 & 2.86 & 79.47 & 0.63 \\
$\mathbf{M g}^{\times}$ & 0.17 & 1.53 & 1.95 & 0.54 \\
$\mathbf{C a}^{\times}$ & 0.20 & 2.04 & 3.10 & 0.57 \\
$\mathbf{K}^{\times}$ & 0.10 & 0.59 & 0.27 & 0.49 \\
$\mathbf{N a}^{\times}$ & 0.05 & 0.40 & 0.05 & 0.33 \\
$\mathbf{P}^{*}$ & 0.51 & 1.56 & 10.92 & 0.79 \\
$\mathbf{N i}^{*}$ & 0.02 & 4.50 & 0.82 & 1.53 \\
$\mathbf{C u}^{*}$ & 0.18 & 2.87 & 1.29 & 0.61 \\
$\mathbf{Z n} *$ & 0.14 & 2.19 & 1.97 & 1.35 \\
\hline
\end{tabular}

*Measured in mg nutrient per $\mathrm{kg}$ of soil.

${ }^{\times}$Measured in cmol charge per $\mathrm{kg}$ of soil.

$\dagger$ Calculated as the proportion of sample $<2 \mathrm{~mm}$ in size.

- Measured in microSiemans

$\uparrow$ Coefficient of Variation

It is unclear if soil nutrients definitively affected the different yield between the two sites used in this study. Kering et al (2012) found that application of P increased yield at one site but not another in southern Oklahoma. In another long term study, P rate did not affect production (Muir et al., 2001). Other information on effects of soil nutrients and switchgrass yield is limited. In general, $\mathrm{P}$ plays a vital role in energy transfer as high-energy phosphate in the chemical structures adenosine diphosphate (ADP) and adenosine triphosphate (ATP), and K plays a role in metabolic activity, photosynthesis, and the efficiency of water use (Marschner, 1988).

Phosphorus deficiency in plants is commonly characterized by stunted growth and K deficiency 
is characterized by reduced drought tolerance and increased lodging (Brady and Weil, 2008).

These visual indicators on switchgrass tissues were not apparent at the Coal-Mac site at the time of the collection. Magnesium, Al, and Fe levels likely varied due to different rock type and differing rates of weathering at the sites.

\subsubsection{Soil Particle Size Analysis}

Results of the soil particle size analysis indicated that the textural class best suited to describe Black Castle is loam and Coal-Mac is sandy loam (Table 4.7). The 10 samples from Black Castle used for the analysis had an average percent sand of 51.3, average percent silt of 35.3, and average percent clay of 13.5. Coal-Mac showed a higher percent sand when compared to Black Castle. The samples used for particle size analysis from Coal-Mac had an average percent sand of 60.2, average percent silt of 27.8, an average percent clay of 12.0.

Table 4.8: Soil particle size distribution by site plus or minus one standard deviation.

\begin{tabular}{lccc}
\hline & \% Sand & \%Silt & \%Clay \\
\hline Black Castle & 51.3 & 35.3 & 13.5 \\
& $( \pm 4.9)$ & $( \pm 3.9)$ & $( \pm 2.7)$ \\
Coal-Mac & 60.2 & 27.8 & 12.0 \\
& $( \pm 12.3)$ & $( \pm 9.0)$ & $( \pm 3.7)$ \\
\hline
\end{tabular}

\subsection{Summary and Conclusions}

In this study, addition of $\mathrm{N}$ fertilizer improved switchgrass cover, frequency and yield. After just one growing season, plots fertilized with either treatment of $\mathrm{N}$ achieved satisfactory growth for reclamation purposes. These findings, which indicate that switchgrass yield is improved by addition of N, are in line with many studies (Muir et al., 2001; Vogel et al., 2002; 
Mulkey et al., 2006). Even plots receiving no addition of fertilizer still showed signs of being capable to support switchgrass growth, which was expected. Soils properties appeared to be significantly better at Black Castle than Coal-Mac due to increases in macro and micronutrients in spite of differences in top soil depths. These findings indicate why yield was greater at Black Castle compared to Coal-Mac during the first year. Continual monitoring of these sites may eventually show a separation between treatment levels, especially the plots with the two different levels of $\mathrm{N}$ application. Additionally, annual application of fertilizer could provide valuable long-term information for mine operators and/or land owners. Based on the information gathered in this study, Cave-in-Rock switchgrass can grow successful stands on mine soils reclaimed similarly to how Black Castle and Coal-Mac were reclaimed. Furthermore, adequate cover and frequency were accomplished with half $\left(33.6 \mathrm{~kg} \mathrm{~N} \mathrm{ha}^{-1}\right)$ of the West Virginia Surface Mining Reclamation Regulation's minimum standard (WV DEP, 2002). Information from varying amounts of hydromulch on yield was not significant. 


\section{Literature Cited:}

Arch Coal Inc. 2012. Our Mines. http://www.archcoal.com/aboutus/coalmac.aspx. Copyright 2000-2012 Arch Coal Inc. Holden, WV.

Brady, N.C and R.R. Weil. 2008. The Nature and Properties of Soils (14 ${ }^{\text {th }}$ ed). Pearson Education, Inc., Upper Saddle River, New Jersey.

Daubenmire, R. 1956. A canopy-coverage method of vegetational analysis. Northwest Science 33:43-64.

Dunifon., S.N., G.K. Evanylo, R.O. Maguire, and J.M. Goatley, Jr., 2011. Soil nutrient and Fescue (Festuca spp.) response to compost and hyrdoseed on a disturbed roadside. Compost Science and Utilization 19:147-151.

ESRI. 2011. ArcGIS Desktop: Release 10. Redlands, CA: Environmental Systems Research Institute.

Faraway, J.J. 2004. Linear Models with R. Chapman and Hall/CRC Press, Boca Raton, Florida.

Gee, G.W. and J.W. Bauder. 1986. Particle-size analysis. p. 383-411. In A Klute (ed.) Methods of Soil Analysis, Part 1. Physical and Mineralogical Methods. Agronomy Monograph No. 9 (2ed). American Society of Agronomy/Soil Science Society of America, Madison, WI

Haque, M., F.M. Epplin, and C.M. Taliaferro. 2009. Nitrogen and Harvest Frequency Effect on Yield and Cost for Four Perennial Grasses. Agronomy Journal 101:1463-1469.

Kering, M.K., J.T. Biermacher, T.J. Butler, J. Mosali, and J.A. Guretzky. 2012. Biomass Yield and Nutrient Responses of Switchgrass to Phosphorus Application. Bioenergy Resources 5: 71-78.

Marschner, H. 1988. Mineral Nutrition of Higher Plants. Academic Press., London.

Muir, J.P., M.A. Sanderson, W.R. Ocumpaugh, R.M. Jones, and R.L. Reed. 2001. Biomass production of Alamo switchgrass in response to nitrogen, phosphorus, and row spacing. Agronomy Journal 93: 896-901.

Mulkey, V.R., V.N. Owens, and D.K. Lee. 2006. Management of switchgrass-dominated conservation reserve program lands for biomass production in South Dakota. Crop Science 46:712-720.

Parrish, D.J., J.H. Fike, D.I. Bransby and R. Samson. 2008. Establishing and managing switchgrass as an energy crop. Forage and Grazinglands doi: 10.1094/FG-2008-0220-01RV. 
R Core Team. 2012. R: A language and environment for statistical computing. R Foundation for Statistical Computing, Vienna, Austria. ISBN 3-900051-070. http://www.r-project.org.

SAS Insititue. 2008. SAS/STAT systems for windows v.9.2. SAS Institute, Cary, N.C.

Vogel, K.P., J.J. Brejda, D.T. Walters and D.R. Buxton. 2002. Switchgrass biomass production in the Midwest USA: harvest and nitrogen management. Agronomy Journal 94: 413-420

West Virginia Department of Environmental Protection. 2002. West Virginia Surface Mining Reclamation Regulations (July 15, 2002). (http://www.dep.wvu.gov/dmr/codes). §38-2-9. Revegetation.

Wolf, A. and Beegle, D. 1995. Recommended soil tests for macronutrients: Phosphorus, Potassium, Calcium and Magnesium. p. 30-38. In Sims, J.T. and A.M. Wolf (ed.). Recommended soil testing procedures for the Northeastern United States. Northeastern Regional Pub. No. 493 (2nd edition). Agricultural Experiment Station Univ. of Delaware, Newark, DE. 


\section{5: Yield potential of a one- and two-harvest system of switchgrass grown on two reclaimed surface mines in West Virginia}

\subsection{Introduction}

This chapter examines yield from two harvest management systems for switchgrass (Panicum virgatum L.) grown on reclaimed surface mines in West Virginia. One- and twoharvest management systems for switchgrass production on reclaimed surface mines were compared using the Hampshire Hill and Hobet 21 mine sites used in Chapter 3 of this thesis. The one-harvest system was taken at the end of the growing season when plants were in the later phases of the seed ripening stage (Moore et al., 1991). Yield results of the one-harvest system were compared to yields of switchgrass collected at mid-summer combined with the regrowth collected at the end of the growing season. The second harvest of the two-harvest system was collected on the same date as the collection of the one-cut system at each site. The objective of this study was to determine which system may be most appropriate for switchgrass production grown as a reclamation species for biomass on mines in West Virginia.

\subsection{Materials and Methods}

\subsubsection{Site Locations}

For this study to determine harvest system effects on yield, we used the Hampshire Hill and Hobet 21 surface mines. These studies had been established in 2008 (see Chapter 3 for descriptions of reclamation and plot design and planting for these two sites). 


\subsubsection{Experimental Design}

As described previously, three varieties, Cave-in-Rock, Carthage, and Shawnee, were planted in 0.4-ha plots replicated three times for a total of nine plots per site. Each 0.4-hectare plot, at both sites, was randomly assigned one switchgrass variety and seeded at a rate of $11.2 \mathrm{~kg}$ pure live seed (PLS) ha ${ }^{-1}$ using a hand broadcast seeder (Keene and Skousen, 2009).

Switchgrass sampling was conducted at both sites at six randomly selected points. Specific sampling techniques are discussed in upcoming sections, but all samples for yield collection were taken using the same coordinates. Sampling points within each plot were randomly selected and recorded using a Global Positioning System (GPS) (GARMIN eTrex Vista H) (Figures 5.1 and 5.2). For the purpose of this document, the term yield is described as above ground switchgrass biomass clipped at a stubble height of 5 to $8 \mathrm{~cm}$, dried at $60^{\circ} \mathrm{C}$ to a constant weight and weighed to determine dry matter weight.

Figure 5.1: Site layout of Hampshire Hill showing varieties and sampling points.

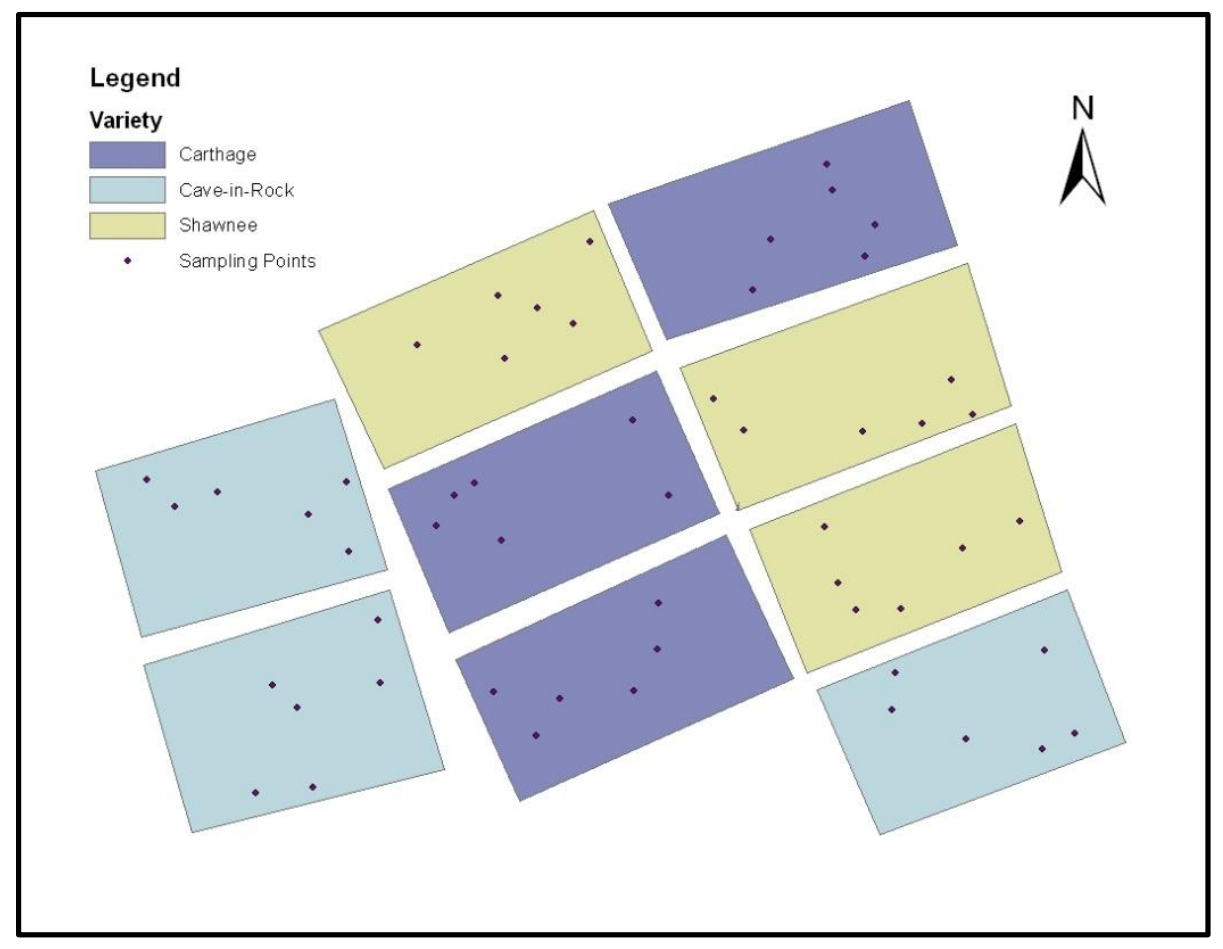


Figure 5.2: Site layout of Hobet 21 showing varieties and sampling points.

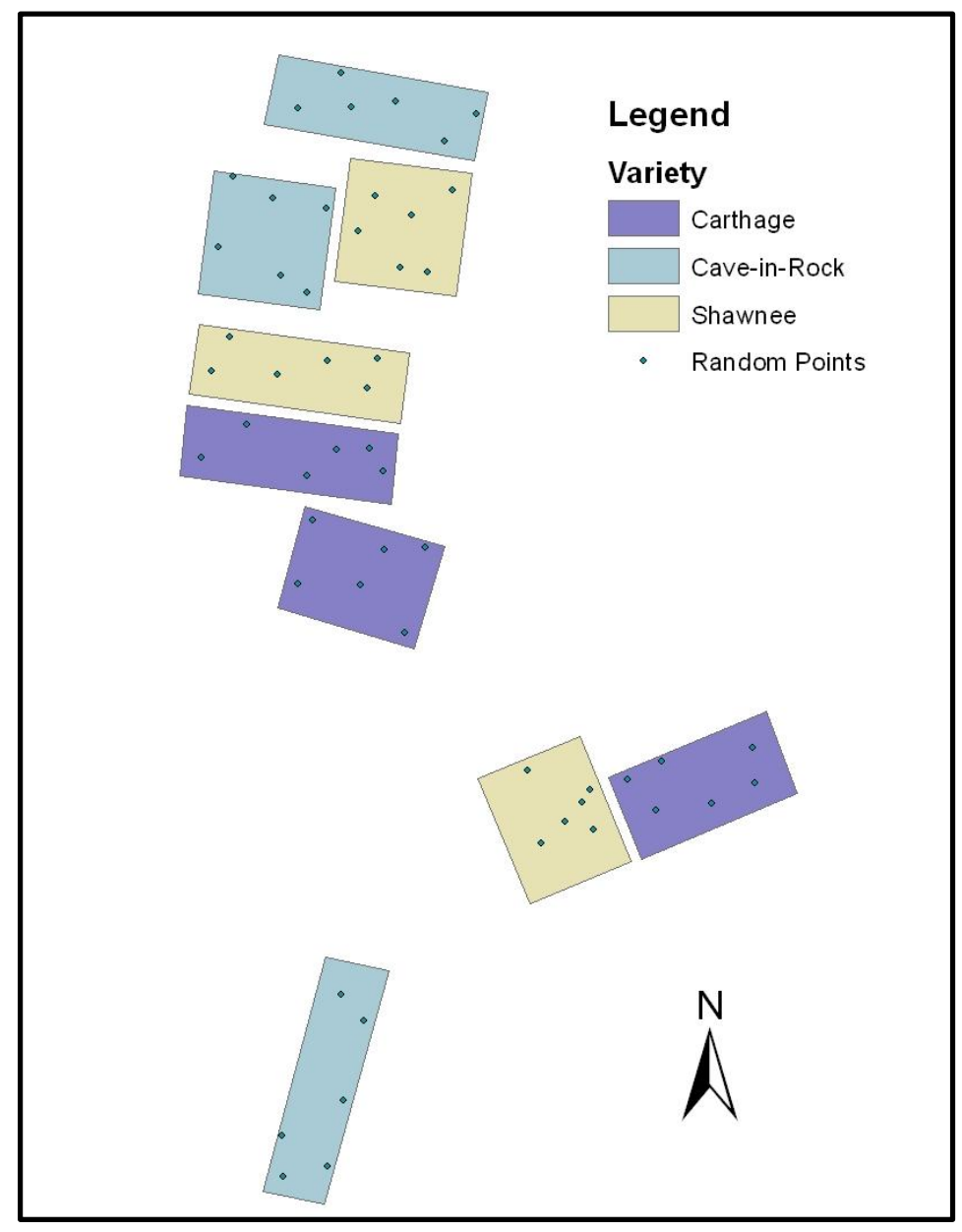

\subsubsection{Vegetation Measurement and Analysis}

For this experiment, biomass was collected to represent two harvest management types. Yield was determined by clipping all switchgrass within a $0.21-\mathrm{m}^{2}$ quadrat at six randomly selected sampling locations within each plot. Biomass was clipped using garden shears. Collection was done at a stubble height of approximately 5 to $8 \mathrm{~cm}$, which was common to previous studies at these sites. If no switchgrass was found inside the quadrat during any collection period, a zero was recorded for the sample location. 
The two-harvest system determined total yields of switchgrass cut at two periods during the growing season. All two-harvest system samples were taken five paces due north of each of the six sampling points. The first harvest of the two-harvest system occurred on July $19^{\text {th }}$ at the Hobet 21 site and July $25^{\text {th }}$ at the Hampshire Hill site. While collecting the first harvest of the two-harvest system, a wooden stake was driven into the bottom left corner of each quadrat and marked with a bright colored marking paint and flagging. With the aid of a handheld Global Positioning System (GPS) (Garmin eTrex Vista H) and the coordinates of each sampling point, the marked wooden stake was located at the time of the second harvest. The regrowth was collected by orienting the quadrat so the marked stake was located at the bottom left corner, as it was during the first collection (Figure 5.3). Once positioned, all regrowth was collected within the quadrat in the same manner as described above. Additionally, during collection of the first cut, approximately 1-m surrounding each quadrat was clipped at the same stubble height and discarded. Trimming the area around the quadrat assisted in finding the location of the quadrat for the second harvest and may have reduced border effects caused by shading from vegetation outside of the quadrat. 
Figure 5.3: Two-harvest switchgrass biomass collection- showing brightly painted wooden stake placed at the bottom left corner of quadrat.

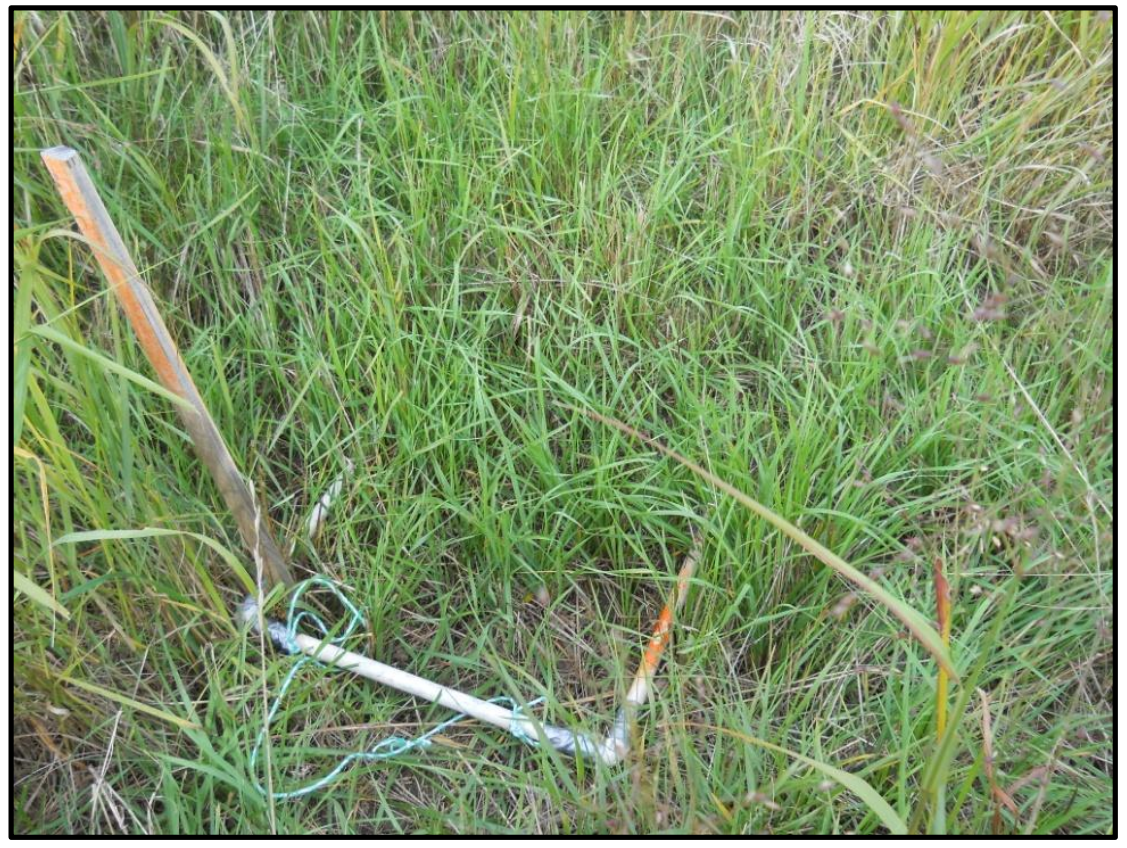

Although this study focused more on date of first harvest, a visual survey of the growth stage of the switchgrass stand at the time of the first harvest was estimated according the growth stages of perennial forage grasses (Moore et al., 1991). The switchgrass plants at the Hampshire Hill site were predominately at boot stage or just prior to boot stage, otherwise called stem elongation (Figure 5.3). A majority of the stand at Hobet 21 had flowers partially or fully emerged and therefore had begun the reproductive growth stage. At the time of final collection, the switchgrass plants at both sites were at the later phase of seed ripening stage, (Moore et al., 1991) and the regrowth was clipped from the same plots. All one-harvest system samples were taken five paces due south of each sampling point. One-harvest collection occurred September $27^{\text {th }}$ at the Hobet 21 site and October $10^{\text {th }}$ at Hampshire Hill. All samples were oven dried at 60 ${ }^{\circ} \mathrm{C}$ to constant weight, then weighed. 
Switchgrass yield from these plots was used to assess the main effects of switchgrass variety, site and harvest type as well as to determine interactions among the main effects. Switchgrass variety, site and harvest type were considered fixed effects. Yield data from harvest type were analyzed using a factorial analysis of variance (ANOVA) by SAS (2008) using a mixed model procedure. The independent categorical variables used for this analysis were site, variety and harvest type. Yield was a dependent response variable. Statistical significance was based on a p-value of 0.05. All yield data used for statistical analysis were square root transformed in order to satisfy the assumption of a normal distribution required for the analysis.

The relationship between yield and the main effects of switchgrass variety, site, and harvest type was examined in two different ways. First, we assessed whether yields from the one-harvest system were different than the total yield of the two-harvest system using ANOVA. In this case, total yield of the two-harvest system was calculated by adding the yield collected in July to regrowth collected at the end of the growing season for each sampling point (the growth from July to the end of the growing season). In the second approach, we compared yields from different cuttings within the two-harvest system as well as to the one-harvest system. Therefore, comparisons were made among two-harvest total yield, one-harvest yield, July yield only, and the regrowth from July until the end of the growing season only.

\subsection{Results and Discussion}

Averaged across sites and variety, untransformed yield from the one-harvest system was $3029 \mathrm{~kg} \mathrm{ha}^{-1}$ and total yield of the two-harvest system was $2922 \mathrm{~kg} \mathrm{ha}^{-1}$. ANOVA results (Tables 5.1 and 5.4) showed no significant difference between yields between harvest system type $(\mathrm{p}$-value $=0.5500)$. Therefore there was no evident yield advantage when harvesting 
switchgrass twice per growing season compared to once at the end of the growing season.

Additionally, site*harvest type and variety*harvest type interactions were not significant, which indicates that the yield, based on harvest-type, is independent of site and variety. It should be noted that ANOVA results from this test did show that the main effects of site and variety were significant at a p-value $<0.05$ (Tables 5.1 and 5.4). Results discussing the reasons for site and variety effects on yield were discussed in Chapter 3 of this thesis and therefore were not repeated here (Table 5.2 displays the original table of repeated measures ANOVA analysis from Chapter 3).

Table 5.1: Harvest type ANOVA table with yield as the response variable. Yield in this analysis used one-harvest system and total of two-harvest system data.

\begin{tabular}{lllll}
\hline Effect & DF & Den DF & F Value & Pr $>$ F \\
\hline Site & 1 & 28 & 48.39 & $<0.0001^{*}$ \\
Variety & 2 & 28 & 5.30 & $0.0112^{*}$ \\
Harvest Type & 1 & 28 & 0.37 & 0.5500 \\
Site*Harvest Type & 1 & 28 & 0.08 & 0.7765 \\
Variety*Harvest Type & 2 & 28 & 0.20 & 0.8238 \\
\hline
\end{tabular}

*Indicates significance at a $\mathrm{p}=0.05$ level.

Table 5.2: Table 3.2 from Chapter 3 showing significance associated with the main effects, site and variety in a repeated measures ANOVA with yield as the response variable.

\begin{tabular}{lllll}
\hline Effect & DF & Den DF & F Value & Pr $>\mathbf{F}$ \\
\hline Site & 1 & 25.5 & 321.50 & $<0.0001^{*}$ \\
Variety & 2 & 25.5 & 7.66 & $0.0025^{*}$ \\
Year & 2 & 23.8 & 43.60 & $<0.0001^{*}$ \\
Site*variety & 2 & 27.2 & 16.35 & $<0.0001^{*}$ \\
Variety*year & 4 & 26.1 & 0.77 & 0.5558 \\
Site*year & 2 & 23.8 & 1.92 & 0.1680
\end{tabular}

\footnotetext{
*Indicates significance at a $\mathrm{p}=0.05$ level.
} 
Yield collected in July and the regrowth collected in October were included in a second statistical analysis. Examination of main effects (Tables 5.3 and 5.4) revealed slightly different results than comparing only one-harvest yield to total yield of the two-harvest system, which was discussed above. Unchanged from the ANOVA discussed above and what was reported in Chapter 3 (Table 5.2), the main effects of site and variety were significant. However, in this analysis, harvest type was a significant effect (p-value < 0.0001). Many studies have found that different harvest systems can affect switchgrass yield (Thomason et al., 2004; Vogel et al., 2002;

Fike et al., 2006; Haque et al., 2009)

Table 5.3: Harvest type ANOVA results with yield as the response variable. Yield in this analysis used all one- and two-harvest system data, including yields collected in July only, regrowth only, and total combined yield, along with the one-harvest system.

\begin{tabular}{lllll}
\hline Effect & DF & Den DF & F Value & Pr>F \\
\hline Site & 1 & 28 & 48.39 & $<0.0001^{*}$ \\
Variety & 2 & 28 & 5.30 & $0.0002^{*}$ \\
Harvest Type & 2 & 28 & 0.37 & $<0.0001^{*}$ \\
Site*Harvest Type & 2 & 28 & 0.08 & $0.0412^{*}$ \\
Variety*Harvest Type & 4 & 28 & 0.20 & 0.8421 \\
\hline
\end{tabular}

*Indicates significance at a $\mathrm{p}=0.05$ level. 
Table 5.4: ANOVA Results and mean yields for Switchgrass grown under a one- and twoharvest system.

\begin{tabular}{|c|c|c|c|c|c|c|}
\hline \multicolumn{2}{|l|}{ Effect } & $\mathbf{P}>\mathbf{F}^{*}$ & $\begin{array}{l}\text { Mean } \\
\text { Kg/ha }\end{array}$ & \multirow[t]{2}{*}{ Square } & $\begin{array}{c}\text { S.D. } \\
\text { oot Yield }\end{array}$ & $\begin{array}{c}\text { COV } \\
\text { Data* }\end{array}$ \\
\hline Harvest Type & & NS & & & & \\
\hline (Analysis 1) & & & 3029 & 48.9 & 25.9 & 0.53 \\
\hline & One-Harvest & & 2922 & 45.4 & 30.2 & 0.66 \\
\hline & Two-Harvest & & & & & \\
\hline \multirow{7}{*}{$\begin{array}{l}\text { Harvest Type*Site } \\
\text { (Analysis 1) }\end{array}$} & & NS & & & & \\
\hline & Hobet 21 & & & & & \\
\hline & One-Harvest & & 946 & 29.5 & 9.4 & 0.32 \\
\hline & Two-Harvest & & 631 & 24.2 & 7.0 & 0.29 \\
\hline & Hampshire Hill & & & & & \\
\hline & One-Harvest & & 5112 & 68.4 & 22.0 & 0.32 \\
\hline & Two-Harvest & & 5213 & 66.6 & 29.7 & 0.45 \\
\hline \multirow{5}{*}{$\begin{array}{l}\text { Harvest Type } \\
\text { (Analysis 2) }\end{array}$} & & $<0.0001$ & & & & \\
\hline & One-Harvest & & $3029^{A}$ & $48.9^{\mathrm{A}}$ & 25.9 & 0.53 \\
\hline & Two-Harvest & & $2922^{A}$ & $45.4^{\mathrm{A}}$ & 30.2 & 0.66 \\
\hline & July & & $2504^{\mathrm{A}}$ & $41.7^{\mathrm{A}}$ & 28.4 & 0.68 \\
\hline & October & & $419^{B}$ & $17.3^{\mathrm{B}}$ & 11.2 & 0.64 \\
\hline
\end{tabular}

Harvest Type*Site

0.04

(Analysis 2)

\section{Hobet 21}

One-Harvest

Two-Harvest

July

October

$\begin{array}{cccc}\mathbf{9 4 6}^{\mathbf{A}} & 29.5^{\mathrm{A}} & 9.4 & 0.32 \\ \mathbf{6 3 1}^{\mathbf{A B}} & 24.2^{\mathrm{AB}} & 7.0 & 0.29 \\ \mathbf{5 2 8}^{\mathbf{A B}} & 21.9^{\mathrm{AB}} & 7.4 & 0.34 \\ \mathbf{1 0 3}^{\mathbf{B}} & 10.0^{\mathrm{B}} & 2.1 & 0.21\end{array}$

Hampshire Hill

One-Harvest

Two-Harvest

July

$5112^{\mathrm{A}}$

$\mathbf{5 2 1 3}^{\mathrm{A}}$

$68.4^{\mathrm{A}}$

22.0

0.32

October

$4479^{\mathrm{A}}$

$66.6^{\mathrm{A}}$

29.7

0.45

$734^{B}$

$61.6^{\mathrm{A}}$

27.9

0.45

$24.7^{\mathrm{B}}$

11.7

0.48

Averaged across site and variety, untransformed yield data was $3029 \mathrm{~kg} \mathrm{ha}^{-1}$ for the oneharvest system, $2922 \mathrm{~kg} \mathrm{ha}^{-1}$ for the total yield of the two-harvest system, $2504 \mathrm{~kg} \mathrm{ha}^{-1}$ for yield 
collected in July, and $419 \mathrm{~kg} \mathrm{ha}^{-1}$ for yield regrowth from July to October. Mean-level contrasts (Tables 5.4 and 5.5) show the regrowth from July to October added a negligible amount to the total yield. Yields collected in July (growth from spring to July) were significantly different (pvalue $<0.001$ ) than yields collected in October (growth from July to October, the regrowth), which was expected. Furthermore, yields collected in July compared to the total yield of the two-harvest system did not show a significant difference ( $\mathrm{p}$-value $=0.4938)$. Comparing yields collected in July to data from the one-harvest system also showed no significant difference (pvalue $=0.1785)$

Table 5.5: Contrasts of switchgrass biomass yield by harvest type.

\begin{tabular}{ll}
\hline Harvest Type & Pr $>$ F
\end{tabular}

Two-harvest system total vs. July yield 0.4892

July yield vs. October yield (Regrowth) <.0001*

One-harvest system vs. July yield 0.1785

$\dagger$ Harvest time contrasts were based on square root transformed data

*Indicates significance at a $\mathrm{p}=0.05$ level.

Warranting some discussion is the significance of the site*harvest type interaction (pvalue $=0.0412)$ produced in the second analysis (Tables 5.3 and 5.4). This interaction indicates that yields based on harvest type are behaving differently at Hampshire Hill and Hobet 21. Examination of untransformed yield data, however, suggests that both sites had relatively good yield production from the one-harvest system, two-harvest system (total), and July yield collection and had relatively poor yield production for the regrowth from July to October (Table 5.6). Statistical significance of this site*harvest type interaction was initially thought to be based on the magnitude of difference between yield production by the two sites. Mean-level comparisons using transformed yield data revealed harvest treatment type at that the more fertile 
site, Hampshire Hill (Table 5.6), were in line with the analysis above examining transformed yield data averaged across site (Tables 5.4 and 5.5). At Hampshire Hill, both one- and twoharvest systems produced comparable yields. Yield collected in July provided the majority of the two-harvest system and was comparable to the one-harvest system yield. The regrowth collected from July to October provided very little yield. Hobet 21 provided slightly different results in some aspects. Similar to Hampshire Hill there was no significant yield advantage when using a two-harvest system at Hobet 21. Hobet 21 differed from Hampshire Hill in that there was no significant difference between July yield and the regrowth collected in October.

Table 5.6: Untransformed switchgrass yield by harvest time and site.

\begin{tabular}{lcc}
\hline Harvest Type & Hampshire Hill & Hobet 21 \\
\hline One-harvest system & $5111.6^{\mathrm{A}}$ & $945.8^{\mathrm{A}}$ \\
Two-harvest system (total) & $5213.4^{\mathrm{A}}$ & $631.0^{\mathrm{AB}}$ \\
July yield & $4479.2^{\mathrm{A}}$ & $527.9^{\mathrm{AB}}$ \\
October yield (Regrowth) & $734.2^{\mathrm{B}^{*}}$ & $103.1^{\mathrm{B} \neq}$ \\
\hline
\end{tabular}

\footnotetext{
*Indicates yield significant difference within site at a $\mathrm{p}=0.001$ level. $\ddagger$ Indicates yield significant at a $\mathrm{P}=0.100$ level.
}

Results indicate that there is no benefit to employing a two-harvest system, similar to the one designed for this project, for switchgrass grown on reclaimed surface mines. Similar yields were obtained regardless of harvest-type. Our results contradict other studies which found that yield of upland switchgrass varieties increased with multiple harvests (Vogel et al., 2002 and Fike et al., 2006b). However, other studies report there is no yield advantage to multiple harvests of switchgrass (Balasko et al. 1984; Sanderson et al., 1999 and Haque et al., 2009). In our study, 
switchgrass had a poor response to a harvest in October after a harvest in July, which is consistent to other studies (Haque et al., 2009; Sanderson et al., 1999; and McLaughlin and Kszoz, 2005). Most vegetation collected from July to October was leafy material in contrast to the hard, woody stems clipped at other harvest periods.

In our study, harvesting once per year seems to be optimal for maximizing switchgrass yields while minimizing resources for growth on reclaimed surface mines. A once per year harvest at the end of the growing season could increase stand longevity while saving time and resources. A study conducted by Mulkey et al. (2006) concluded that harvesting switchgrass once per year after a killing frost will optimize yield production. Additionally, Mulkey et al., (2006) reported that switchgrass yields declined over a three year span when harvested at anthesis, but reported no decline in yields per year when harvested at a killing frost. A late harvest, such as after a killing frost, is also thought to benefit switchgrass conversion to biofuel as moisture content is reduced as well as $\mathrm{N}$ content (Hohenstein and Wright, 1994) caused by translocation of nutrients to the belowground portion of the plants. The translocation of $\mathrm{N}$ and $\mathrm{C}$ compounds back to plant roots and crowns is also thought to increase stand longevity (Sanderson et al., 1999 and Muir et al., 2001).

We chose not to fertilize sites with the goal to gain an understanding of switchgrass production on reclaimed surface mines without increasing work or costs to mine operators. However, to obtain greater yields, especially with a two-harvest system, addition of $\mathrm{N}$ fertilizer may be necessary. In Fike et al (2006b), upland varieties, including Cave-in-Rock, responded positively ( $28 \%$ yield increase) to a two-harvest system fertilized with $100 \mathrm{~kg} \mathrm{~N} \mathrm{ha}^{-1} \mathrm{yr}^{-1}$ compared to a one-harvest system fertilized with $50 \mathrm{~kg} \mathrm{~N} \mathrm{ha}^{-1} \mathrm{yr}^{-1}$ on stands six to nine years old. Fike et al. (2006a) saw a yield increase of $38 \%$ on the same stand from years three to five. 


\subsection{Summary and Conclusions}

Yield results of a one-harvest system were compared to yields of switchgrass collected at mid-summer combined with the regrowth collected at the end of the growing season at two reclaimed mined sites. No significant difference was found between yields at either site for harvest system. Further, yields collected at the first-cut of the two-harvest system were not significantly different from the yields at the end of the year for the one-harvest system.

Continuation of this study is recommended to understand the effects of one- versus two-harvest systems over time on reclaimed surface mines. Including a treatment of $\mathrm{N}$ fertilizer to this study may also be beneficial to mine operators. Utilizing fertilization rates mentioned above or the rates used at Black Castle and Coal-Mac mine sites descripted in Chapter 4 would assist in created management practices for maximizing yield of switchgrass grown on reclaimed surface mines in the state of West Virginia. 


\section{Literature Cited}

Balasko, J.A., D.M. Burner, and W.V. Thayne. 1984. Yield and quality of switchgrass grown without soil amendments. Agronomy Journal 76:204-208.

Fike, J.H., D.J. Parrish, D.D. Wolf, J.A. Balasko, J.T. Green, Jr., M. Rasnake and J.H. Reynolds. 2006a. Long-term yield potential of switchgrass-for-biofuel systems. Biomass and Bioenergy 30:198-206.

Fike, J.H., D.J. Parrish, D.D. Wolf, J.A. Balasko, J.T. Green, Jr., M. Rasnake and J.H. Reynolds. 2006b. Switchgrass production for the upper southeastern USA: Influence of cultivar and cutting frequency on biomass yields. Biomass and Bioenergy 30:207-213.

Haque, M., F.M. Epplin, and C.M. Taliaferro. 2009. Nitrogen and Harvest Frequency Effect on Yield and Cost for Four Perennial Grasses. Agronomy Journal 101:1463-1469.

Hohenstein, W.G. and L.L. Wright. 1994. Biomass energy production in the United States: An overview. Biomass Bioenergy 6:161-173.

Keene, T. and J. Skousen. 2009. Switchgrass production potential on reclaimed surface mines in West Virginia. In R.I. Barnhisel (ed.) Proceedings, $26^{\text {th }}$ meeting, American Society for Mining and Reclamation, May 30 -June 5, 2009. Billings, Montana.

McLaughlin, S.B. and L.A. Kszos. 2005. Development of switchgrass (Pancium virgatum) as a bioenergy feedstock in the United States. Biomass and Bioenergy 28: 515-535.

Moore, K.J., L.E. Moser, K.P. Vogel, S.S. Waller, B.E. Johnson and J.F. Pedersen. 1991. Describing and quantifying growth stages of perennial grasses. Agronomy Journal 83: 10731077.

Muir, J.P., M.A. Sanderson, W.R. Ocumpaugh, R.M. Jones, and R.L. Reed. 2001. Biomass production of Alamo switchgrass in response to nitrogen, phosphorus, and row spacing. Agronomy Journal 93: 896-901.

Mulkey, V.R., V.N. Owens and D.K. Lee. 2006. Management of switchgrass-dominated Conservation Reserve Program lands for biomass production in South Dakota. Crop Science 46:712-720

Sanderson, M.A., J.C. Read, R.L. Reed. 1999. Harvest management of switchgrass for biomass feedstock production. Agronomy Journal 91:5-10.

SAS Institute. 2008. SAS/STAT systems for windows v.9.2. SAS Institute, Cary, N.C.

Thomason, W.E., W.R. Raun, G.V. Johnson, C.M. Taliaferro, K.W. Freeman, K.J. Wynn, and 
R.W. Mullen. 2004. Switchgrass response to harvest frequency and time and rate of applied nitrogen. Journal of Plant Nutrition 27:1199-1226.

Vogel, K.P., J.J. Brejda, D.T. Walters and D.R. Buxton. 2002. Switchgrass biomass production in the Midwest USA: harvest and nitrogen management. Agronomy Journal 94: 413-420 


\section{APPENDIX}

\section{Appendix 1. Sampling Point Coordinates}

Hampshire Hill sampling points:

$\begin{array}{ccc}\text { ID } & \text { Latitude } & \text { Longitude } \\ 1 & 39.43645778 & -79.0597523 \\ 2 & 39.4365401 & -79.05971633 \\ 3 & 39.43663637 & -79.0598586 \\ 4 & 39.43670621 & -79.05987798 \\ 5 & 39.43650814 & -79.06007427 \\ 6 & 39.43637622 & -79.0601398 \\ 7 & 39.43608763 & -79.06028321 \\ 8 & 39.43600489 & -79.06017983 \\ 9 & 39.43599357 & -79.05977253 \\ 10 & 39.43601154 & -79.05956781 \\ 11 & 39.43612702 & -79.05946538 \\ 12 & 39.43603188 & -79.05939374 \\ 13 & 39.43574237 & -79.0599099 \\ 14 & 39.43559181 & -79.05987088 \\ 15 & 39.43552131 & -79.05980812 \\ 16 & 39.43551962 & -79.05965554 \\ 17 & 39.43567701 & -79.05943965 \\ 18 & 39.43574787 & -79.05924251 \\ 19 & 39.43540184 & -79.05916828 \\ 20 & 39.43535074 & -79.0596797 \\ 21 & 39.43525264 & -79.05969375 \\ 22 & 39.435171 & -79.05944166 \\ 23 & 39.43513913 & -79.05918036 \\ 24 & 39.43518038 & -79.05906863 \\ 25 & 39.43520424 & -79.060914 \\ 26 & 39.43532259 & -79.06105796 \\ 27 & 39.43530057 & -79.06083169 \\ 28 & 39.43531896 & -79.06057578 \\ 29 & 39.43542708 & -79.06049156 \\ 30 & 39.43555102 & -79.0604868 \\ 31 & 39.43583362 & -79.06044295 \\ 32 & 39.436038 & -79.06056026 \\ 33 & 39.43572549 & -79.06101987 \\ 34 & 39.43576836 & -79.06123944\end{array}$




$\begin{array}{lcc}35 & 39.43584693 & -79.06117608 \\ 36 & 39.43587924 & -79.06110719 \\ 37 & 39.4362484 & -79.06129164 \\ 38 & 39.43620688 & -79.06099477 \\ 39 & 39.43629555 & -79.060757 \\ 40 & 39.43634059 & -79.060878 \\ 41 & 39.4363743 & -79.06101391 \\ 42 & 39.43651211 & -79.06069328 \\ 43 & 39.43588874 & -79.06154554 \\ 44 & 39.43570365 & -79.06154091 \\ 45 & 39.43580516 & -79.06167706 \\ 46 & 39.43586873 & -79.06198713 \\ 47 & 39.43583379 & -79.06213454 \\ 48 & 39.43590579 & -79.06222877 \\ 49 & 39.43552129 & -79.06144755 \\ 50 & 39.43535301 & -79.06144486 \\ 51 & 39.43535518 & -79.06181468 \\ 52 & 39.43529367 & -79.0617323 \\ 53 & 39.43508038 & -79.06168152 \\ 54 & 39.43506972 & -79.06187711\end{array}$

Hobet 21 sampling points:

$\begin{array}{ccc}\text { ID } & \text { Latitude } & \text { Longitude } \\ 1 & 38.06486168 & -81.96955549 \\ 2 & 38.06504055 & -81.96984693 \\ 3 & 38.06500451 & -81.97042755 \\ 4 & 38.06517196 & -81.97017378 \\ 5 & 38.06501633 & -81.97011222 \\ 6 & 38.06499008 & -81.96936935 \\ 7 & 38.06424652 & -81.9696487 \\ 8 & 38.06426873 & -81.96980888 \\ 9 & 38.06443361 & -81.97006352 \\ 10 & 38.06460234 & -81.96996168 \\ 11 & 38.06451341 & -81.96974777 \\ 12 & 38.06463202 & -81.96950453 \\ 13 & 38.06454183 & -81.97025295 \\ 14 & 38.06458759 & -81.97056694 \\ 15 & 38.06468147 & -81.97080465 \\ 16 & 38.06435674 & -81.97088914 \\ 17 & 38.06422691 & -81.9705174\end{array}$




$\begin{array}{lcc}18 & 38.06414535 & -81.97035789 \\ 19 & 38.06370522 & -81.96999753 \\ 20 & 38.06376406 & -81.97052937 \\ 21 & 38.06377571 & -81.9709209 \\ 22 & 38.06393673 & -81.97081278 \\ 23 & 38.06382994 & -81.97023501 \\ 24 & 38.06383916 & -81.96993787 \\ 25 & 38.06331353 & -81.96990058 \\ 26 & 38.06329283 & -81.97034649 \\ 27 & 38.06337187 & -81.97097799 \\ 28 & 38.06352719 & -81.97070708 \\ 29 & 38.06341361 & -81.97017575 \\ 30 & 38.0634194 & -81.96997987 \\ 31 & 38.06296107 & -81.96964736 \\ 32 & 38.06294976 & -81.96988532 \\ 33 & 38.0630842 & -81.97031372 \\ 34 & 38.0627874 & -81.97039578 \\ 35 & 38.0627853 & -81.97002681 \\ 36 & 38.06256193 & -81.96976412 \\ 37 & 38.06192507 & -81.96902827 \\ 38 & 38.06178023 & -81.96870347 \\ 39 & 38.06183689 & -81.96865461 \\ 40 & 38.06165358 & -81.96863315 \\ 41 & 38.0616913 & -81.96880171 \\ 42 & 38.06158627 & -81.96894504 \\ 43 & 38.06188936 & -81.96843827 \\ 44 & 38.06197486 & -81.96823769 \\ 45 & 38.06204133 & -81.96769773 \\ 46 & 38.06187905 & -81.9676844 \\ 47 & 38.06178023 & -81.96793921 \\ 48 & 38.06174704 & -81.96826761 \\ 49 & 38.06075094 & -81.96997893 \\ 50 & 38.06037619 & -81.97009844 \\ 51 & 38.06007057 & -81.97018556 \\ 52 & 38.06001819 & -81.97044573 \\ 53 & 38.06021122 & -81.97045697 \\ 54 & 38.06087364 & -81.97011742\end{array}$

\section{Black Castle sampling points:}

$\begin{array}{ccc}\text { ID } & \text { Latitude } & \text { Longitude } \\ \text { P1T1 } & 38.0710675 & -81.73106866\end{array}$




\begin{tabular}{|c|c|c|}
\hline P1T1 & 38.07102035 & -81.73115817 \\
\hline P1T1 & 38.07081568 & -81.73100573 \\
\hline $\mathrm{P} 1 \mathrm{~T} 2$ & 38.07075364 & -81.73092581 \\
\hline P1T2 & 38.07074887 & -81.73087578 \\
\hline P1T2 & 38.07072588 & -81.7307362 \\
\hline P1T3 & 38.07121391 & -81.73089325 \\
\hline P1T3 & 38.07132767 & -81.73091733 \\
\hline P1T3 & 38.07114529 & -81.73090064 \\
\hline P1T4 & 38.0711328 & -81.73050645 \\
\hline P1T4 & 38.07115105 & -81.73074582 \\
\hline P1T4 & 38.0710421 & -81.73059358 \\
\hline P2T1 & 38.07015488 & -81.73109957 \\
\hline P2T1 & 38.07030744 & -81.7309447 \\
\hline P2T1 & 38.07009055 & -81.73091406 \\
\hline $\mathrm{P} 2 \mathrm{~T} 2$ & 38.07063422 & -81.73133714 \\
\hline $\mathrm{P} 2 \mathrm{~T} 2$ & 38.07057349 & -81.73124057 \\
\hline $\mathrm{P} 2 \mathrm{~T} 2$ & 38.07059428 & -81.73107502 \\
\hline P2T3 & 38.07033022 & -81.73139011 \\
\hline Р2T3 & 38.07021201 & -81.73124556 \\
\hline Р2T3 & 38.07040227 & -81.73119418 \\
\hline P2T4 & 38.07043017 & -81.73075883 \\
\hline P2T4 & 38.07038946 & -81.73082985 \\
\hline P2T4 & 38.07047223 & -81.73099843 \\
\hline P3T1 & 38.07105938 & -81.73135375 \\
\hline P3T1 & 38.07106923 & -81.7314228 \\
\hline P3T1 & 38.07119051 & -81.7314376 \\
\hline P3T2 & 38.07159052 & -81.7315162 \\
\hline P3T2 & 38.07157782 & -81.73156425 \\
\hline P3T2 & 38.07146813 & -81.73173907 \\
\hline P3T3 & 38.07121183 & -81.73120676 \\
\hline P3T3 & 38.07153518 & -81.73136151 \\
\hline P3T3 & 38.07129732 & -81.73139955 \\
\hline P3T4 & 38.07119499 & -81.73163101 \\
\hline P3T4 & 38.07122789 & -81.73185466 \\
\hline P3T4 & 38.07116516 & -81.73178267 \\
\hline P4T1 & 38.07078252 & -81.73203855 \\
\hline P4T1 & 38.07069178 & -81.73187553 \\
\hline P4T1 & 38.07077484 & -81.7320759 \\
\hline P4T2 & 38.0710525 & -81.73190332 \\
\hline P4T2 & 38.07079719 & -81.73179717 \\
\hline P4T2 & 38.07091917 & -81.73187986 \\
\hline P4T3 & 38.07043669 & -81.73162393 \\
\hline P4T3 & 38.07057306 & -81.73172349 \\
\hline
\end{tabular}




$\begin{array}{lcc}\text { P4T3 } & 38.07060643 & -81.73160685 \\ \text { P4T4 } & 38.07067196 & -81.73144708 \\ \text { P4T4 } & 38.07067623 & -81.73149951 \\ \text { P4T4 } & 38.07077508 & -81.73169317 \\ \text { P5T1 } & 38.07201153 & -81.73272034 \\ \text { P5T1 } & 38.07179806 & -81.73267504 \\ \text { P5T1 } & 38.07179184 & -81.73257015 \\ \text { P5T2 } & 38.07140698 & -81.7323408 \\ \text { P5T2 } & 38.07165991 & -81.73254948 \\ \text { P5T2 } & 38.07142498 & -81.73223236 \\ \text { P5T3 } & 38.07217308 & -81.73252873 \\ \text { P5T3 } & 38.07203737 & -81.73246313 \\ \text { P5T3 } & 38.0718235 & -81.7323809 \\ \text { P5T4 } & 38.07176734 & -81.73233158 \\ \text { P5T4 } & 38.07154494 & -81.73208358 \\ \text { P5T4 } & 38.07164106 & -81.73200578\end{array}$

Coal-Mac sampling points:

$\begin{array}{lcc}\text { ID } & \text { Latitude } & \text { Longitude } \\ \text { P1T1_CM } & 37.73163869 & -82.07522969 \\ \text { P1T1_CM } & 37.73149115 & -82.0752516 \\ \text { P1T1_CM } & 37.73168407 & -82.07527332 \\ \text { P1T2_CM } & 37.73170873 & -82.07504601 \\ \text { P1T2_CM } & 37.73175801 & -82.07488236 \\ \text { P1T2_CM } & 37.73181346 & -82.07515201 \\ \text { P1T3_CM } & 37.73185876 & -82.07566477 \\ \text { P1T3_CM } & 37.7317245 & -82.07548319 \\ \text { P1T3_CM } & 37.73187848 & -82.07538878 \\ \text { P1T4_CM } & 37.73213211 & -82.07521417 \\ \text { P1T4_CM } & 37.7319957 & -82.07512865 \\ \text { P1T4_CM } & 37.73203195 & -82.07527643 \\ \text { P2T1_CM } & 37.7312879 & -82.07439659 \\ \text { P2T1_CM } & 37.73140348 & -82.07433449 \\ \text { P2T1_CM } & 37.73130329 & -82.07457027 \\ \text { P2T2_CM } & 37.73139969 & -82.07501194 \\ \text { P2T2_CM } & 37.73146304 & -82.07508239 \\ \text { P2T2_CM } & 37.7314631 & -82.07482451 \\ \text { P2T3_CM } & 37.73126026 & -82.07466161 \\ \text { P2T3_CM } & 37.73104715 & -82.07479051 \\ \text { P2T3_CM } & 37.73113883 & -82.07464857\end{array}$




$\begin{array}{lll}\text { P2T4_CM } & 37.73156302 & -82.07482902 \\ \text { P2T4_CM } & 37.73167757 & -82.07460298 \\ \text { P2T4_CM } & 37.73159401 & -82.07458015 \\ \text { P3T1_CM } & 37.73133568 & -82.07601488 \\ \text { P3T1_CM } & 37.73147691 & -82.07569131 \\ \text { P3T1_CM } & 37.73129056 & -82.07587058 \\ \text { P3T2_CM } & 37.73112968 & -82.07615758 \\ \text { P3T2_CM } & 37.73105006 & -82.0762938 \\ \text { P3T2_CM } & 37.73117616 & -82.07627014 \\ \text { P3T3_CM } & 37.73131185 & -82.07553324 \\ \text { P3T3_CM } & 37.73126478 & -82.07570285 \\ \text { P3T3_CM } & 37.73117563 & -82.0758104 \\ \text { P3T4_CM } & 37.73097165 & -82.07607384 \\ \text { P3T4_CM } & 37.73104256 & -82.07586327 \\ \text { P3T4_CM } & 37.73094831 & -82.07596172 \\ \text { P4T1_CM } & 37.73103894 & -82.07505424 \\ \text { P4T1_CM } & 37.73085798 & -82.07493449 \\ \text { P4T1_CM } & 37.73086707 & -82.0751488 \\ \text { P4T2_CM } & 37.73096273 & -82.0754535 \\ \text { P4T2_CM } & 37.73087949 & -82.07558818 \\ \text { P4T2_CM } & 37.73100779 & -82.07566052 \\ \text { P4T3_CM } & 37.73111538 & -82.07518849 \\ \text { P4T3_CM } & 37.73118968 & -82.07532285 \\ \text { P4T3_CM } & 37.73131997 & -82.07524612 \\ \text { P4T4_CM } & 37.73081505 & -82.0752985 \\ \text { P4T4_CM } & 37.73070684 & -82.07521283 \\ \text { P4T4_CM } & 37.73070628 & -82.07529213 \\ \text { P5T1_CM } & 37.73041127 & -82.07645734 \\ \text { P5T1_CM } & 37.73042598 & -82.07654916 \\ \text { P5T1_CM } & 37.73055397 & -82.07644755 \\ \text { P5T2_CM } & 37.73061473 & -82.07590063 \\ \text { P5T2_CM } & 37.73052301 & -82.0760767 \\ \text { P5T2_CM } & 37.73070149 & -82.07606401 \\ \text { P5T3_CM } & 37.73078247 & -82.07613689 \\ \text { P5T3_CM } & 37.73073678 & -82.07641377 \\ \text { P5T3_CM } & 37.73080556 & -82.07638428 \\ \text { P5T4_CM } & 37.73022418 & -82.07614461 \\ \text { P5T4_CM } & 37.73034203 & -82.07611908 \\ \text { P5T4_CM } & 37.73032721 & -82.07626727\end{array}$


Appendix 2. Repeated Measures ANOVA Results and mean yields for Switchgrass grown on reclaimed surface mines during the second, third and fourth years of growth.

\begin{tabular}{|c|c|c|c|c|c|c|c|}
\hline \multirow[t]{2}{*}{ Effect } & & $\mathbf{P}>\mathbf{F}^{*}$ & Mean & S.D. $\dagger$ & Mean & S.D. $\dagger$ & $\mathrm{CV} \pm$ \\
\hline & & & \multicolumn{2}{|c|}{$---\mathrm{kg} \mathrm{ha}^{-1}-\cdots$} & \multicolumn{3}{|c|}{----Square Root Yield Data*--- } \\
\hline \multirow[t]{3}{*}{ Site } & & $<.0001$ & & & & & \\
\hline & Hampshire Hill & & $5760^{A}$ & 734 & $25.5^{\mathrm{A}}$ & 17.5 & 0.69 \\
\hline & Hobet 21 & & $\mathbf{8 0 3}^{B}$ & 2389 & $73.9^{\mathrm{B}}$ & 12.6 & 0.17 \\
\hline \multirow[t]{4}{*}{ Variety } & & .0025 & & & & & \\
\hline & Cave-in-Rock & & $4298^{A}$ & 3853 & $55.9^{\mathrm{A}}$ & 35.2 & 0.63 \\
\hline & Carthage & & $2479^{B}$ & 2460 & $43.0^{\mathrm{B}}$ & 25.8 & 0.60 \\
\hline & Shawnee & & $3069^{A}$ & 2520 & $50.2^{\mathrm{A}}$ & 24.2 & 0.48 \\
\hline \multirow[t]{4}{*}{ Year } & & $<.0001$ & & & & & \\
\hline & 2009 & & $2359^{\mathrm{C}}$ & 2472 & $39.7^{\mathrm{C}}$ & 28.8 & 0.73 \\
\hline & 2010 & & $4457^{\mathrm{A}}$ & 3511 & $60.5^{\mathrm{A}}$ & 29.0 & 0.48 \\
\hline & 2011 & & $3029^{B}$ & 2363 & $48.9^{\mathrm{B}}$ & 25.9 & 0.53 \\
\hline \multirow[t]{9}{*}{ Site*Variety } & & $<.0001$ & & & & & \\
\hline & Hobet 21 & & & & & & \\
\hline & Cave-in-Rock & & $\mathbf{7 4 3} 3^{B}$ & 751 & $23.7^{\mathrm{B}}$ & 14.4 & 0.61 \\
\hline & Carthage & & $581^{B}$ & 419 & $22.3^{\mathrm{B}}$ & 9.6 & 0.43 \\
\hline & Shawnee & & $1086^{A}$ & 930 & $30.5^{\mathrm{A}}$ & 13.3 & 0.44 \\
\hline & Hampshire Hill & & & & & & \\
\hline & Cave-in-Rock & & $\mathbf{7 8 5 3}^{\mathrm{A}}$ & 1594 & $88.2^{\mathrm{A}}$ & 8.7 & 0.10 \\
\hline & Carthage & & $4376^{B}$ & 2141 & $63.7^{\mathrm{B}}$ & 19.0 & 0.30 \\
\hline & Shawnee & & $5051^{B}$ & 1945 & $69.9^{\mathrm{B}}$ & 13.8 & 0.20 \\
\hline \multirow[t]{12}{*}{ Variety* Year } & & NS & & & & & \\
\hline & 2009 & & & & & & \\
\hline & Cave in Rock & & 3275 & 3523 & 44.3 & 39.7 & 0.90 \\
\hline & Carthage & & 1859 & 2021 & 35.2 & 27.2 & 0.77 \\
\hline & $\begin{array}{l}\text { Shawnee } \\
\mathbf{2 0 1 0}\end{array}$ & & 1944 & 1664 & 39.5 & 21.4 & 0.54 \\
\hline & Cave in Rock & & 5140 & 4594 & 63.8 & 35.8 & 0.56 \\
\hline & Carthage & & 3640 & 3219 & 53.7 & 30.1 & 0.56 \\
\hline & Shawnee & & 4592 & 3010 & 64.0 & 24.3 & 0.38 \\
\hline & 2011 & & & & & & \\
\hline & Cave in Rock & & 4479 & 3848 & 59.8 & 33.0 & 0.55 \\
\hline & Carthage & & 1938 & 1924 & 40.1 & 19.8 & 0.49 \\
\hline & Shawnee & & 2669 & 2293 & 46.9 & 23.7 & 0.50 \\
\hline
\end{tabular}

Site*Year

Hampshire Hill

2009

2010

2011

NS

Hobet 21

2009

$\begin{array}{ccccc}4502 & 1615 & 66.1 & 12.0 & 0.18 \\ 7668 & 1514 & 87.2 & 8.7 & 0.10 \\ 5112 & 2703 & 68.4 & 22.0 & 0.32 \\ & & & & \\ 217 & 224 & 13.2 & 6.9 & 0.52\end{array}$


2010

2011

Site*Variety*Year

Hampshire Hill

Hobet 21
2009

Cave in Rock

Carthage

Shawnee

2010

Cave in Rock

Carthage

Shawnee

2011

Cave in Rock

Carthage

Shawnee

2009

Cave in Rock

Carthage

Shawnee

2010

Cave in Rock

Carthage

Shawnee

2011

Cave in Rock

Carthage

Shawnee

NS

33.8

29.5
845

$946 \quad 597$

497

$3592 \quad 1095$

$3436 \quad 425$

$9222 \quad 1588$

$6560 \quad 462$

$7221 \quad 815$

$\begin{array}{ll}7860 & 1321\end{array}$

$2978 \quad 2430$

$4497 \quad 1689$

$\begin{array}{ll}72 & 48\end{array}$

$125 \quad 63$

$452 \quad 261$

$1058 \quad 501$

$\begin{array}{ll}720 & 319\end{array}$

$1964 \quad 1124$

$1099 \quad 993$

$897 \quad 326$

$842 \quad 526$
80.4

59.4

58.5

95.8

81.0

84.9

88.5

50.7

66.2

8.1

11.0

20.5

31.8

26.4

43.2

31.1

29.6

27.7
10.8

9.4

0.32

0.32

${ }^{*}$ Statistics and p-values determined using square root transformed data.

$\dagger$ Standard Deviation

\pm Coefficient of Variation 
Appendix 3. Two-way ANOVA Results and mean yields for Switchgrass grown using four establishment treatment methods.

\begin{tabular}{|c|c|c|c|c|c|c|c|}
\hline \multicolumn{2}{|l|}{ Effect } & $\mathbf{P}>\mathbf{F}^{*}$ & Mean & S.D. $\dagger$ & Mean & S.D. $\dagger$ & $\mathrm{COV} \pm$ \\
\hline \multirow{3}{*}{ Site } & & & \multicolumn{2}{|c|}{$-----k^{\prime} h^{-1}----$} & \multicolumn{3}{|c|}{----Square Root Yield Data*---- } \\
\hline & Coal-Mac & 0.0087 & $248^{B}$ & 206 & $136^{\mathrm{B}}$ & 81 & 059 \\
\hline & Black Castle & & $\mathbf{5 4 3}^{\mathrm{A}}$ & 546 & $19.3^{\mathrm{A}}$ & 13.3 & 0.69 \\
\hline \multirow[t]{5}{*}{ Treatment } & & 0.00004 & & & & & \\
\hline & No Fertilizer; light mulch & & $67^{\mathrm{B}}$ & 169 & $3.9^{\mathrm{B}}$ & 7.6 & 1.95 \\
\hline & $33.6 \mathrm{~kg} \mathrm{~N} \mathrm{ha}^{-1}$; light mulch & & $362^{A}$ & 313 & $17.4^{\mathrm{A}}$ & 8.0 & 0.46 \\
\hline & $33.6 \mathrm{~kg} \mathrm{~N} \mathrm{ha}^{-1}$; heavy mulch & & $375^{\mathrm{A}}$ & 196 & $18.8^{\mathrm{A}}$ & 5.1 & 0.27 \\
\hline & $67 \mathrm{~kg} \mathrm{~N} \mathrm{ha}^{-1}$, light mulch & & $777^{\mathrm{A}}$ & 606 & $25.8^{\mathrm{A}}$ & 11.1 & 0.43 \\
\hline \multirow[t]{11}{*}{ Site*Treatment } & & NS & & & & & \\
\hline & Coal-Mac & & & & & & \\
\hline & No Fertilizer; light mulch & & 116 & 238 & 5.9 & 10.1 & 1.70 \\
\hline & $33.6 \mathrm{~kg} \mathrm{~N} \mathrm{ha}^{-1}$; light mulch & & 278 & 261 & 15.2 & 7.8 & 0.51 \\
\hline & $33.6 \mathrm{~kg} \mathrm{~N} \mathrm{ha}^{-1}$; heavy mulch & & 256 & 127 & 15.6 & 4.0 & 0.25 \\
\hline & $67 \mathrm{~kg} \mathrm{~N} \mathrm{ha}^{-1}$, light mulch & & 341 & 164 & 17.8 & 5.5 & 0.31 \\
\hline & Black Castle & & & & & & \\
\hline & No Fertilizer; light mulch & & 17 & 39 & 1.9 & 4.2 & 2.24 \\
\hline & $33.6 \mathrm{~kg} \mathrm{~N} \mathrm{ha}^{-1}$; light mulch & & 447 & 366 & 19.7 & 8.5 & 0.43 \\
\hline & $33.6 \mathrm{~kg} \mathrm{~N} \mathrm{ha}^{-1}$; heavy mulch & & 495 & 185 & 21.9 & 4.2 & 0.19 \\
\hline & $67 \mathrm{~kg} \mathrm{~N} \mathrm{ha}^{-1}$, light mulch & & 1212 & 570 & 33.8 & 9.2 & 0.27 \\
\hline
\end{tabular}

* Statistics and p-values determined using square root transformed data.

$\dagger$ Standard Deviation

\pm Coefficient of Variation 
Appendix 4. ANOVA Results and mean yields for Switchgrass grown under a one- and two-harvest systems.

\begin{tabular}{|c|c|c|c|c|c|c|c|}
\hline \multicolumn{2}{|l|}{ Effect } & $\mathbf{P}>\mathbf{F}^{*}$ & \multirow{2}{*}{\multicolumn{2}{|c|}{ 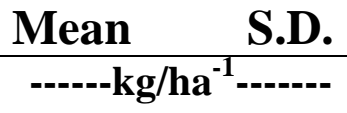 }} & Mean & S.D. & CV \\
\hline & & & & & \multicolumn{3}{|c|}{ Square Root Yield Data* } \\
\hline \multirow{3}{*}{$\begin{array}{l}\text { Harvest Type } \\
\text { (Analysis 1) }\end{array}$} & & NS & & & & & \\
\hline & One-Harvest & & 3029 & 2863 & 48.9 & 25.9 & 0.53 \\
\hline & Two-Harvest & & 2922 & 3162 & 45.4 & 30.2 & 0.66 \\
\hline \multirow{7}{*}{$\begin{array}{l}\text { Harvest Type*Site } \\
\text { (Analysis 1) }\end{array}$} & & NS & & & & & \\
\hline & Hobet 21 & & & & & & \\
\hline & One-Harvest & & 946 & 597 & 29.5 & 9.4 & 0.32 \\
\hline & Two-Harvest & & 631 & 331 & 24.2 & 7.0 & 0.29 \\
\hline & Hampshire Hill & & & & & & \\
\hline & One-Harvest & & 5112 & 2703 & 68.4 & 22.0 & 0.32 \\
\hline & Two-Harvest & & 5213 & 3053 & 66.6 & 29.7 & 0.45 \\
\hline \multirow{5}{*}{$\begin{array}{l}\text { Harvest Type } \\
\text { (Analysis 2) }\end{array}$} & & $<0.0001$ & & & & & \\
\hline & One-Harvest & & $3029^{A}$ & 2863 & $48.9^{\mathrm{A}}$ & 25.9 & 0.53 \\
\hline & Two-Harvest & & $2922^{A}$ & 3162 & $45.4^{\mathrm{A}}$ & 30.2 & 0.66 \\
\hline & July & & $2504^{A}$ & 2746 & $41.7^{\mathrm{A}}$ & 28.4 & 0.68 \\
\hline & October & & $419^{B}$ & 499 & $17.3^{\mathrm{B}}$ & 11.2 & 0.64 \\
\hline
\end{tabular}

Harvest Type*Site

0.04

(Analysis 2)

\section{Hobet 21}

One-Harvest

Two-Harvest

July

October

$\begin{array}{ccccc}\mathbf{9 4 6}^{\mathbf{A}} & 597 & 29.5^{\mathrm{A}} & 9.4 & 0.32 \\ \mathbf{6 3 1}^{\mathbf{A B}} & 331 & 24.2^{\mathrm{AB}} & 7.0 & 0.29 \\ \mathbf{5 2 8}^{\mathbf{A B}} & 324 & 21.9^{\mathrm{AB}} & 7.4 & 0.34 \\ \mathbf{1 0 3}^{\mathbf{B}} & 42 & 10.0^{\mathrm{B}} & 2.1 & 0.21\end{array}$

\section{Hampshire Hill}

One-Harvest

Two-Harvest

July

October

\begin{tabular}{ccccc}
$\mathbf{5 1 1 2}^{\mathbf{A}}$ & 2703 & $68.4^{\mathrm{A}}$ & 22.0 & 0.32 \\
$\mathbf{5 2 1 3}^{\mathbf{A}}$ & 3053 & $66.6^{\mathrm{A}}$ & 29.7 & 0.45 \\
$\mathbf{4 4 7 9}^{\mathbf{A}}$ & 2670 & $61.6^{\mathrm{A}}$ & 27.9 & 0.45 \\
$\mathbf{7 3 4}^{\mathbf{B}}$ & 552 & $24.7^{\mathrm{B}}$ & 11.7 & 0.48 \\
\hline
\end{tabular}

${ }^{*}$ Statistics and p-values determined using square root transformed data.

$\uparrow$ Standard Deviation

\pm Coefficient of Variation 